\title{
Development of an Advanced Continuous Mild Gasification Process for the Production of Coproducts \\ Task 4.6 \\ Technical and Economic Evaluation
}

\section{Topical Report}

\section{R.F. Hogsett \\ M.C. Jha}

December 1991

Work Performed Under Contract No.: DE-AC21-87MC24268

For

U.S. Lepartment of Energy

Office of Fossil Energy

Morgantown Energy Technology Center

Morgant own, West Virginia

By

Western Research Institute

Laramie, Wyoming

and

AMAX Research \& Development Ceriter

Golden, Colorado

and

The Ralph M. Parsons Company

Pasadena, California

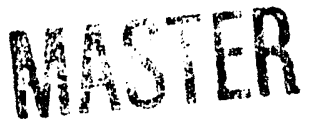




\section{DISCLAIMER}

This report was prepared as an account of work sponsored by an agency of the United States Government. Neither the United States Government nor any agency thereof, nor any of their employees makes any warranty, express or implied, or assumes any legal liability or responsibility for the accuracy, completeness or usefulness of any information, apparatus, product, or process disclosed, or represents that its use would not infringe privately owned rights. Reference herein to any specific commercial product, process, or service by trade name, trademark, manufacturer, or otherwise, does not necessarily constitute or imply its endorsement, recommendation, or favoring by the United States Government or any agency thereof. The views and opinions of authors expressed herein do not necessarily state or reflect those of the United States Government or any agency thereof.

This report has been reproduced directly from the best available copy.

Available to DOE and DOE contractors from the Office of Scientific and Technical Information, P.O. Box 62, Oak Ridge, TN 37831; prices available from (615)576-8401, FTS 626-8401.

Available to the public from the National Technical Information Service, U.S. Department of Commerce, 5285 Port Royal Rd., Springfield, VA 22161. 
Development of an Advanced Continuous Mild Gasification

Process for the Production of Coproducts

Task 4.6

Technical and Economic Evaluation

Topical Report

R.F. Hogsett

M.C. Jha

Work Performed Under Contract No.: DE-AC21-87MC24268

For

U.S. Department of Energy

Office of Fossil Energy

Morgantown Energy Technology Center

P.O. Box 880

Morgantown, West Virginia 26507-0880

Western Research Institute

P.O. Box 3395, University Station

Laramie, Wyoming 82071-3395 and

AMAX Research \& Development Center 5950 McIntyre Street

Golden, Colorado 80403-7499

and

The Ralph M. Parsons Company

Pasadena, California 91124

December 1991 


\section{ABSTRACT}

Under DOE/METC Contract No. DE-AC21-87MC24268, Amax Research \& Development Center of Golden, Colorado (AMAX), worked with Western Research Institute of Laramie, Wyoming (WRI), to develop an advanced continuous mild gasification process for the production of coproducts. This topical report presents the technical and economic evaluation of the process.

Based on the results obtained during bench-scale research and operation of a 100 pound/hour mild gasification process research unit (PRU) and a companion 50 pound/hour char upgrading PRU, a commercial process flowsheet was developed for a 1,000 ton/day coal refinery that will be located at an AMAX coal mine near Gillette, Wyoming. The Ralph M. Parsons Company of Pasadena, California, assisted AMAX in the engineering design and cost estimate for the plant.

The process plant will consist of inclined fluidized-bed dryers and mild gasification reactors, followed by venturi and column scrubbers to collect liquid products. Three marketable liquid products from the plant will be pitch to be used as an anode binder, cresylic acid to be used as chemical feedstock, and oil to be used as fuel for mine equipment.

Hot char will flow into a methanation reactor, where most of the carbon in the char will be converted to methane in an excess of hydrogen. The methane is then heated to a higher temperature to decompose it to pure carbon product and hydrogen for recycle. Pure carbon could be marketed as carbon black for rubber compounding, anode carbon for aluminum smelting, and premium fuel for heat engines. Spent char is upgraded to activated carbon.

The gas produced during mild gasification, coal fines, char ash, and bleed gas from the char upgrading process are used as fuels for the process. Excess energy from the plant, as steam, is converted to electricity in a conventional power plant for internal use and export. The only waste from the plant is the ash from combustion of the waste fuels, which will be disposed of back in the mine as underburden.

The capital cost for the 1,000 ton/day plant is estimated at $\$ 169$ million, which includes $\$ 26$ million as contingency. The annual operating cost is estimated at $\$ 11$ million. The annual revenues are estimated at $\$ 58$ million. An economic evaluation model was used to calculate the DCFROR, assuming zero net present value and 20-year plant life. Sensitivity analysis was performed on the capital cost, operating cost, and product revenues. The DCFROR was 16.4 percent for the base case.

Based on this promising commercialization potential, it is recommended that the project be pursued for additional process development. 


\section{ACKNOWLEDGEMENTS}

The authors would like to acknowledge and show our appreciation and thanks to a number of organizations and people for their support and effort, which was a prerequisite for the successful completion of this task and topical report.

Project funding was provided by the Department of Energy's Morgantown Energy Technical Center under Contract Number DE-AC21-87MC24268 to WRI as prime contractor and then to Amax R\&D under WRI Subcontract Number $\mathbf{8 8 3 0 0 2 .}$ Project managers at METC were Dr. $H$. Fred Bauer during the initial phase of the project and Dr. Richard A. Johnson during the final phase. Project managers at WRI were Dr. Chang-Yul Cha initially and Mr. Norman W. Merriam for the last year.

Two engineering companies participated in the project. At the Stearns-Roger Division of United Engineers \& Constructors of Denver, Colorado, Mr. F. Brian Walter served as process and technical consultant and project leader, while Mr. Richard E. Nilan provided the project engineer role. At the Ralph M. Parsons Company of Pasadena, California, Dr. James B. O'hara provided initial project management and served as process and technical consultant. Subsequent project management was provided by Mr. Steve L. Pelletier. Chief process engineers from Parsons were Mr. Robert A. Johnson and Mr. Derek C. Shelton.

Within the internal AMAX organization, Dr. A. Kumar Bhasin, Director of Amax R\&D, and Mr. Donald K. Craft and Mr. Paul W. Woessner of Amax Coal Industries provided project management and specific input on product revenues and economic evaluation criteria for the project.

Special thanks goes to Ms. Wendy Kennedy of Amax R\&D who over the past few years has provided virtually all of the secretarial skills and word processing duties required for the project. 
Page

ABSTRACT $\ldots \ldots \ldots \ldots \ldots \ldots \ldots \ldots \ldots \ldots \ldots \ldots \ldots \ldots \ldots \ldots \ldots \ldots$

ACKNOWLEDGEMENTS $\ldots \ldots \ldots \ldots \ldots \ldots \ldots \ldots$ ii

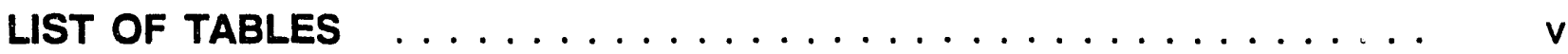

LIST OF FIGURES $\ldots \ldots \ldots \ldots \ldots \ldots \ldots \ldots \ldots \ldots \ldots$ vi

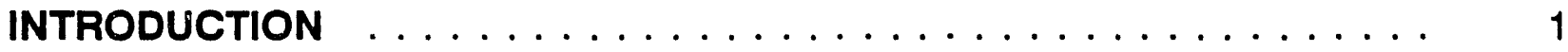

TECHNICAL EVALUATION $\ldots \ldots \ldots \ldots \ldots \ldots \ldots \ldots$

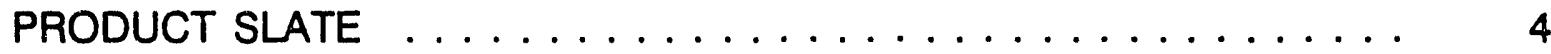

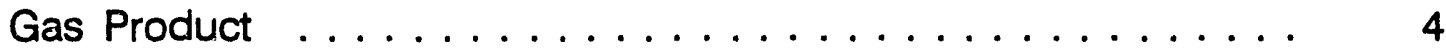

Liquid Products $\ldots \ldots \ldots \ldots \ldots \ldots \ldots \ldots \ldots \ldots$

Solid Products $\ldots \ldots \ldots \ldots \ldots \ldots \ldots \ldots \ldots \ldots \ldots \ldots$

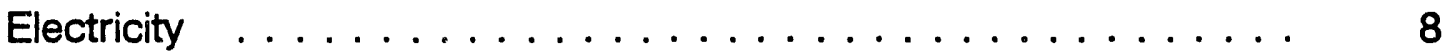

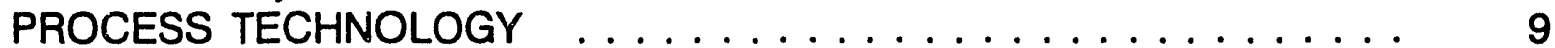

Drying and Mild Gasification $\ldots \ldots \ldots \ldots \ldots \ldots . \ldots$

Condensate Recovery and Upgrading $\ldots \ldots \ldots \ldots \ldots \ldots \ldots$

Char-to-Carbon Process ................... 12

POWER PRODUCTION AND WASTE DISPOSAL $\ldots \ldots \ldots \ldots \ldots$

AREAS REQUIRING FURTHER WORK $\ldots \ldots \ldots \ldots \ldots \ldots \ldots$

COMMERCIAL DEMONSTRATION PLANT PRELIMINARY DESIGN $\ldots$.

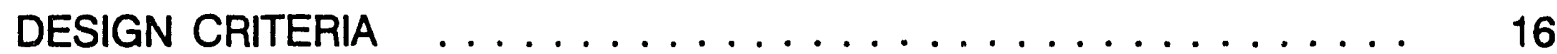

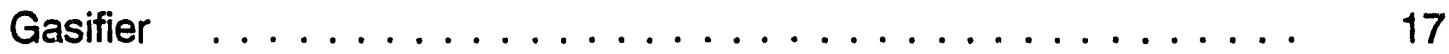

Power Generation $\ldots \ldots \ldots \ldots \ldots \ldots \ldots \ldots \ldots \ldots$

Utility Systems . . . . . . . . . . . . . . . . . . 18

General Facilities and Off Sites . . . . . . . . . . . . 18

Process Configuration ................. 18

PROCESS DESCRIPTION . . . . . . . . . . . . . . . . 19

Coal Drying/Mild Gasification Circuit $\ldots \ldots \ldots \ldots \ldots \ldots \ldots$

Char-to-Carbon Upgrading Facility $\ldots \ldots \ldots \ldots \ldots \ldots \ldots . \ldots 21$

Power Generation ..................... 23

PRODUCT YIELD AND POWER EXPORT $\ldots \ldots \ldots \ldots \ldots \ldots$ 
TABLE OF CONTENTS

(Continued)

COST AND REVEnUE Estimates $\ldots \ldots \ldots \ldots \ldots \ldots \ldots \ldots \ldots$

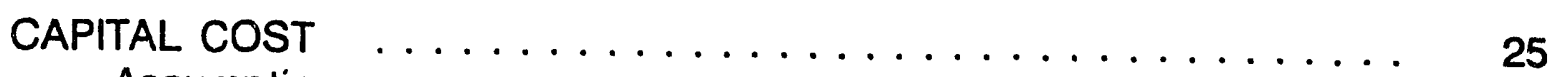

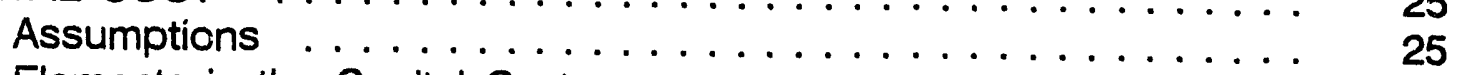

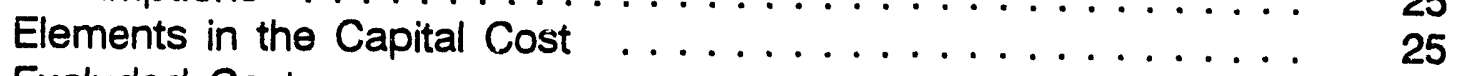

Excluded Costs ....................... 38

OPERATING AND MAINTENANCE COSTS $\ldots \ldots \ldots \ldots \ldots \ldots \ldots$

PRODUCT REVENUES $\ldots \ldots \ldots \ldots \ldots \ldots \ldots \ldots \ldots \ldots \ldots \ldots \ldots \ldots \ldots$

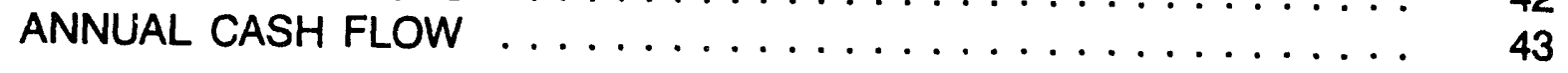

ECONOMIC EVALUATION $\ldots \ldots \ldots \ldots \ldots \ldots \ldots \ldots \ldots$

DCFROR CALCULATIONS $\ldots \ldots \ldots \ldots \ldots \ldots \ldots \ldots \ldots \ldots$

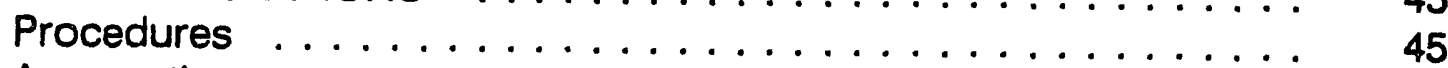

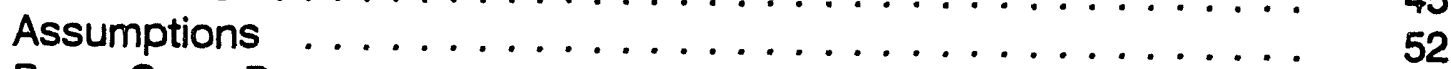

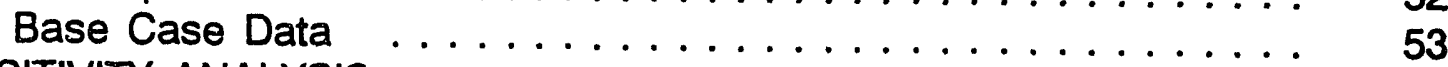

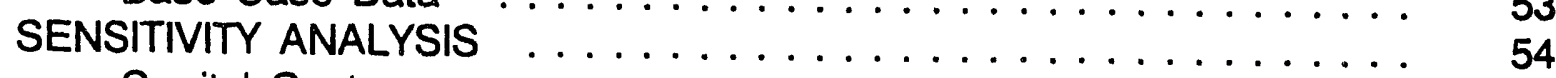

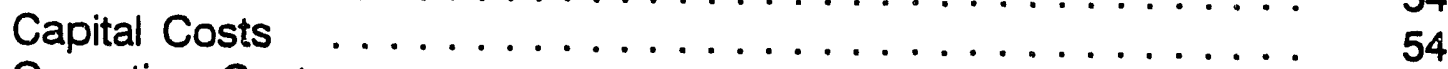

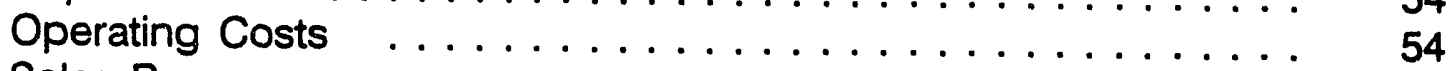

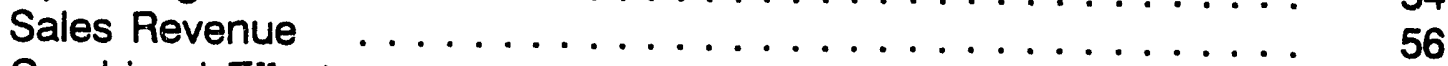

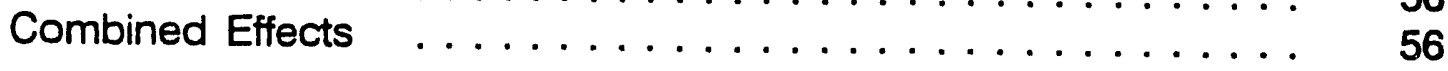

SUMMARY AND CONCLUSIONS $\ldots \ldots \ldots \ldots \ldots \ldots \ldots$

RECOMMENDATIONS $\ldots \ldots \ldots \ldots \ldots \ldots \ldots \ldots \ldots \ldots \ldots \ldots \ldots \ldots$

REFERENCES $\ldots \ldots \ldots \ldots \ldots \ldots \ldots \ldots \ldots \ldots \ldots \ldots \ldots \ldots \ldots$

APPENDIX A

DESIGN PARAMETERS $\ldots \ldots \ldots \ldots \ldots \ldots \ldots \ldots \ldots$

\section{APPENDIX B}

PROCESS FLOW DIAGRAM AND MATERIAL BALANCE $\ldots \ldots \ldots \quad 84$ 


\section{LIST OF TABLES}

Page

Table 1. Major Equipment List and Description $\ldots \ldots \ldots \ldots \ldots . \ldots 27$

Table 2. Major Equipment, Installation Factors, and Costs ....... 33

Table 3. Summary of Total Plant Capital Costs . . . . . . . . . 37

Table 4. Summary of Annual Operating and Maintenance Costs .... 39

Table 5. AMAX 1,000 Ton/Day Operating Cost Summary ........ 40

Table 6. AMAX 1,000 Ton/Day Project Power Usage $\ldots \ldots \ldots . \ldots 41$

Table 7. Operating Labor Estimate $\ldots \ldots \ldots \ldots \ldots \ldots \ldots \ldots$

Table 8. Annua! Plant Product Revenues $\ldots \ldots \ldots \ldots \ldots \ldots \ldots . \ldots 4$

Table 9. Economic Evaluation Using DCFROR Analysis $\ldots \ldots \ldots 46$

Table 10. DCFROR Sensitivity Versus Capital Cost . . . . . . . 54

Table 11. DCFROR Sensitivity Versus Operating Costs ......... 55

Table 12. DCFROR Sensitivity Versus Sales Revenues $\ldots \ldots \ldots 56$ 


\section{LIST OF FIGURES}

Page

Figure 1. Potential products/markets. $\ldots \ldots \ldots \ldots \ldots \ldots$

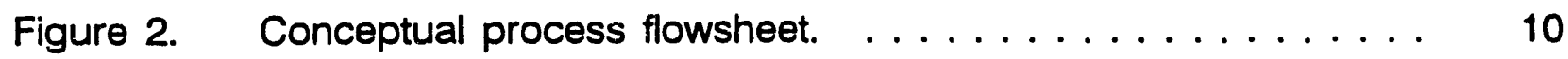

Figure 3. DCFROR sensitivity versus capital cost. $\ldots \ldots \ldots \ldots 5$

Figure 4. DCFROR sensitivity versus operating costs. $\ldots \ldots \ldots \ldots 7$

Figure 5. DCFROR sensitivity versus sales revenues. $\ldots \ldots \ldots \ldots$

Figure 6. DCFROR sensitivity versus revenue and capital. 


\section{INTRODUCTION}

To expand the use of coal, our primary indigenous resource for energy, in an environmentally acceptable and economically feasible manner, the United States Department of Energy (DOE) has been sponsoring research and development of new promising coal conversion technologies. The conversion of coal to liquid and gaseous products can expand the markets for coal into transportation and other sectors of the energy market, as well as in large chemical markets. The enormous costs of liquefaction and gasification processes requiring hydrogen or oxygen plants and high-temperature, high-pressure operations have hampered the commercialization of these processes aimed at producing a single product.

As an alternative approach, Morgantown Energy Technology Center (METC) of DOE has sponsored, and continues to sponsor, programs for the development of technology and market strategies which will lead to the commercialization of processes for the production of coproducts from mild gasification of coal. It has been recognized by DOE and industry that mild gasification is a promising technology with potential to economically convert coal into marketable products, thereby increasing domestic coal utilization.

In this process, coal is devolatilized under non-oxidizing conditions at mild temperature $\left(900-1,100^{\circ} \mathrm{F}\right)$ and pressure $(1-15 \mathrm{psig})$. Condensation of the vapor will yield a liquid product that can be upgraded to a petroleum substitute, and the remaining gas can provide the fuel for the process. The residual char can be burned in a power plant. Thus, in a long-term national scenario, implementation of this process will result in significant decrease of imported oil and increase in coal utilization.

However, before the technology can be made economic for large scale utilization, it has to be developed and demonstrated on a commercial scale. With eventual commercial demonstration as a goal, DOE/METC awarded several contracts in October 1987 to different project teams (consisting of research organizations, coal companies, engineering companies, and potential product users) to develop advanced mild gasification and product upgrading processes for the production of marketable coproducts.

Under one of these contracts, No. DE-AC21-87MC24268, "Development of an Advanced, Continuous Mild Gasification Process for the Production of Coproducts", Amax Research \& Development Center of Golden, Colorado (AiMAX), has been working with Western Research Institute of Laramie, Wyoming (WRI), and Riley Stoker Corporation of Worcester, Massachusetts (RSC). The work has been supplemented by "Development of Char-to-Carbon Process" with technical and financial support from Amax Coal Industries $(\mathrm{ACI})$ and AMAX inc. 
The DOE project consisted of the following four tasks:

Task 1. Literature Survey and Market Assessment

Task 2. Bench-Scale Mild Gasification Study

Task 3. Bench-Scale Char Upgrading Study

Task 4. System Integration Studies

WRI was the prime contractor and had the primary responsibility for development of an inclined fluidized-bed mild gasification process, first at the bench scale under Task 2 and later in a 100 pound/hour process research unit (PRU) under Task 4 with assistance from RSC. AMAX had the primary responsibility for selection of a product slate that would enhance the commercialization potential of the technology (Task 1) and development of a char upgrading process at both the bench scale (Task 3) and in a 50 pound/hour PRU (Task 4).

Task 1 was completed in January 1988 and the findings were published as a topical report. ${ }^{1}$ It was concluded that economic viability of the mild gasification technology, at least for a few initial smaller plants, will critically depend upon upgrading of condensables, and particularly char, to higher-value products. To enhance commercialization potential, AMAX selected an option to convert inexpensive subbituminous coal from Wyoming into products that could be utilized within the company, particularly pitch and pure carbon, to be used in the manufacture of carbon anodes for aluminum production.

A conceptual process flowsheet was developed based on the existing knowledge at that time. Stearns-Roger Division of United Engineers \& Constructors performed a preliminary engineering design and cost estimate for AMAX for a 1,000 ton/day plarit based on this flowsheet. It was estimated that the plant capital cost would be about $\$ 80$ million and the operating cost about $\$ 8$ million in 1988 dollars. Stearns' report was submitted to DOE in October 1988 as a preliminary topical report for Task $4.6^{2}$ Based on this cost estimate and the revenues for products estimated by AMAX, the project economics looked promising and actua! research and development work was initiated.

Since then, all the tasks of the project have been completed. Results from Task 2 were submitted as a topical report by WRI in April $1989^{3}$ and for Task 3 by Amax R\&D in August 1989. ${ }^{4}$ Results of the 100 pound/hour mild gasification PRU operation were presented in a December 1990 WRI topical report. ${ }^{5}$

Results from the companion 50 pound/hour char-to-carbon (CTC) PRU at Golden are being compiled as a topical report and will be submitted to DOE soon. ${ }^{6}$

In late 1990, DOE modified the contract and added Task 4.7 to perform a preliminary design and cost estimate for a 20 ton/day mild gasification and product upgrading process development unit (PDU). Amax R\&D Center coordinated this 
effort and the Ralph M. Parsons Company of Pasadena, California, performed the actual work during the first half of 1991. The PDU design was based on results obtained in Tasks 2, 3, and 4 covered in various topical reports, ${ }^{3-6}$ as well as quarterly progress reports submitted by Amax R\&D Center on Contract No. DE-AC21-87MC24268 and the University of North Dakota Energy and Environmental Research Center, Grand Forks, North Dakota, on Contract No.

DE-AC21-87MC24267. To perform this design, a thorough technical evaluation of the process was performed and alternative approaches were used, which are briefly discussed in the "Technical Evaluation" section of this report. A topical report detailing the PDU design and cost estimate has been submitted to DOE.?

To expedite completion of the project within budget, Amax R\&D Center started working on Task 4.6, Technical and Economic Evaluation of a 1,000 Ton/Day Coal Mild Gasification and Product Upgrading Commercial Demonstration Plant, with the Ralph M. Parsons Company as a subcontractor just as Task 4.7 was being completed but before the completion of the CTC PRU operation. Primary sources for this evaluation were the Stearns' report ${ }^{2}$ and the preliminary design of the PDU. ${ }^{7}$

Since the PDU was designed for 20 tons/day and the commercial demonstration plant (CDP) was to be designed for 1,000 tons/day, a simple scale-up factor of $\mathbf{5 0}$ was used by Parsons for mass balance calculations for the process flowsheet. This was then used to size the equipment and estimate the purchased equipment cost. Amax R\&D observed a significant difference in the installation factors used by Stearns and Parsons. The Stearns' factors appeared more realistic for the size and location of the CDP and were, therefore, used in calculating the installed cost. The power plant, which was not part of the PDU design but was a significant part of the CDP, was costed on an ad hoc basis using Parsons' experience and earlier Stearns' estimate.

The product revenues were estimated based on the product yield calculated from the plant design mass balance, 90 percent operating rate and product price information compiled by Amax Coal Industries ( $\mathrm{ACl}$ ) through discussions with potential users of the product. An $\mathrm{ACl}$ project evaluation model (used for selection of capital projects by $\mathrm{ACl}$ ) was used to perform the economic evaluation, particularly to calculate the discounted rates of return on investment.

This topical report presents the results of this technical and economic evaluation study. 


\section{TECHNICAL EVALUATION}

The primary goal of this prcject, both for DOE and AMAX, has been to develop a mild gasification based technology that could be commercially viable in the near term (mid to late 1050s). AMAX has selected a highly reactive and relatively inexpensive subbituminous Wyodak coal as the feedstock. Since a variety of products will be produced, the project is also called the Wyoming coal refinery (WYCOR) project. The goal is to demonstrate the mild gasification and product upgrading technology in a 1,000 ton/day commercial demonstration plant at an AMAX mine near Gillette, Wyoming.

The project team has been performing a technical evaluation of the process on an ongoing basis so that it will produce marketable products in an economical way. As a result, both the product slate and process technology have changed in an evolutionary fashion over the course of the project, and as discussed in the "Recommendation" section, some more changes may have to be made in the fl'cure to make the project a cornmercial success.

The detailed technical evaluation of various process steps was covered under appropriate topical reports. ${ }^{3-6}$ The objective of the following discussion is to present an overall picture -- the forest and not the trees -- to show how things have evolved and where they are and should be going.

\section{PRODUCT SLATE}

Mild gasification of Wyoming coal in an inclined fluidized-bed reactor produces gaseous, liquid, and solid products. Their utilization and/or upgrading to higher-value marketable products is discussed below under the three headings.

\section{Gas Product}

In the WRI PRU operation with recycling of make gas, about 10 percent of the raw coal was converted to a gas of the following equilibrium composition: ${ }^{5}$

\section{Component Volume \% \\ Content,}

Hydrogen

Carbon Monoxide

Carbon Dioxide

Methane, Hydrocarbons
$10-14$

$17-23$

$25-40$

$29-38$

Unfortunately, indirect heating of this gas to $1,400^{\circ} \mathrm{F}$ will lead to cracking and carbon deposition, as was indeed observed at WRI. Thus, the process flowsheet 
has been modified (as discussed later) whereby combustion products will be used to directly provide heat and fluidization in the mild gasification reactor. This will dilute the make gas to the point where its only possible use can be as a low-grade clean gaseous fuel to provide the heat for the coal drying and mild gasification steps and any surplus for power generation.

\section{Liquid Products}

During the Task 1 study, it was concluded that market acceptance of products from the new technology would be facilitated if they were used within AMAX divisions. Initially, it was thought that there would be three liquid products which would be used in the following way. ${ }^{8}$ The first heavy condensate may contain some solids and this product (dirty pitch) would replace a petroleum oil that Amax Coal Company uses to spray treat dry coal. The next condensate, clean pitch, would be marketed, as such or after some upgrading, as a binder for carbon anodes used in aluminum production. (The Alumax division of AMAX is the third largest aluminum producer in the United States.) Finally, the lighter condensate would be used as a diesel blending stock to run heavy equipment at the mine or rail locomotive engines.

The results obtained during the WRI PRU operation indicated that there was very little contamination of pitch by solids. Thus, the "dirty pitch" has been eliminated from the product slate. Evaluation of a distillate sample by Merichem Company of Houston indicated that the product contained about 40 percent cresylic acid which could be easily separated and marketed to them or somebody else as a chemical feedstock. The remaining part of the distillate could be used as a diesel fuel blend stock. Some preliminary testing performed by Oak Ridge National Laboratory confirmed this potential. ${ }^{9}$

This change in liquid product slate is shown in Figure 1, which shows the potential products and markets for the project. The clean pitch still remains the main liquid product. As will be discussed in the next section, simple air and water cooled condensers in the WRI PRU did not work well in terms of selective condensation. This resulted in tar and water condensing together.

Batch drying and distillation tests were performed on a PRU tar sample to produce a pitch sample that was characterized and evaluated both by Amax R\&D and the Koppers Company of Pittsburgh. It was found that the pitch contained too much oxygen and had low coking yield. Laboratory scale tests indicated that certain thermal treatments improved the pitch quality.

Thus, it was thought that a modified and properly designed condenser in which only the high-boiling tar is condensed and held at a higher temperature for a period of time would yield a clean pitch product that could be marketed directly as an anode binder (at least partial substitution of coke oven pitch which is becoming 


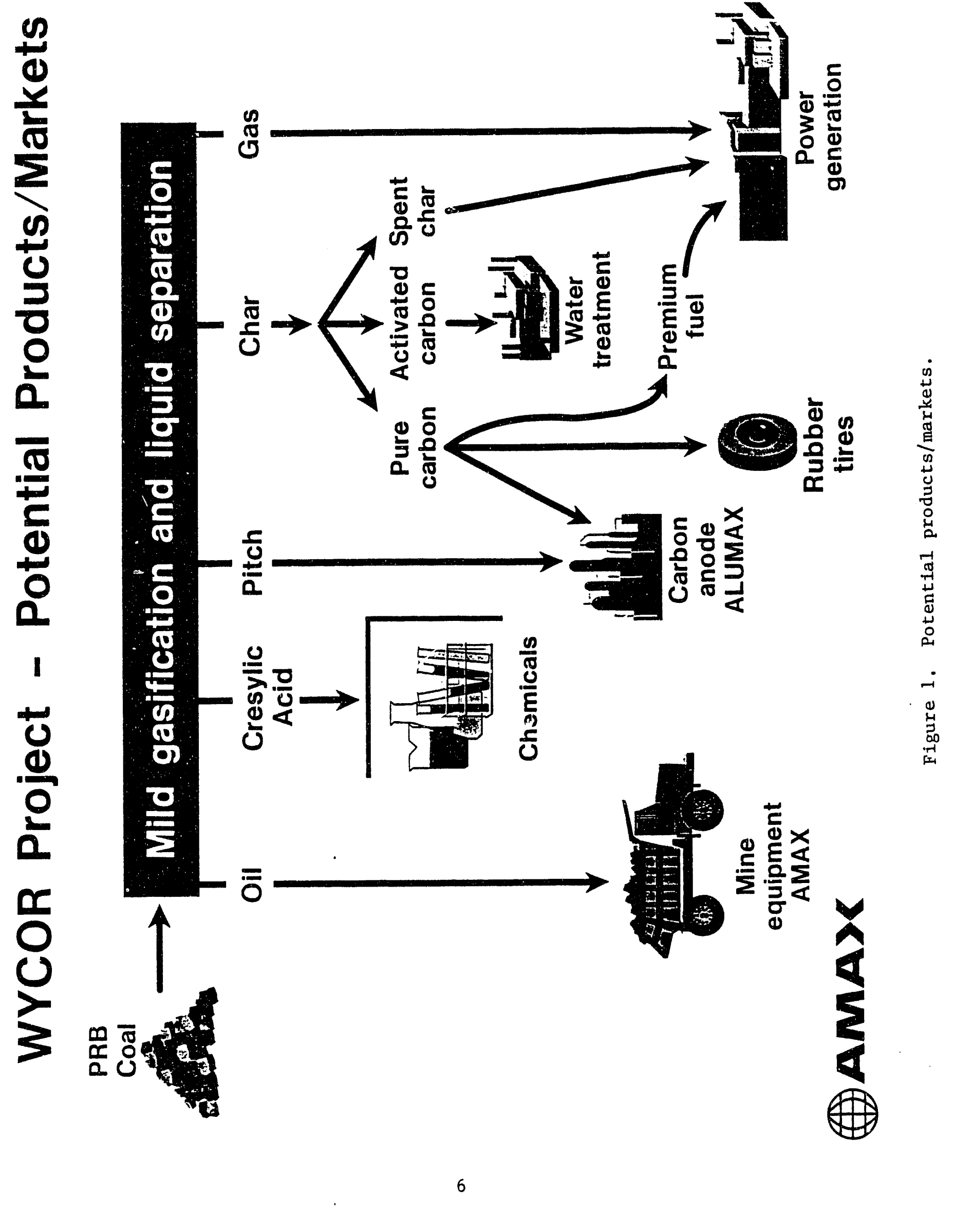


more scarce) or to a tar refiner such as Koppers in Pittsburgh or Riley in Indianapolis.

During the PRU operation at WRI, the total liquid yield was estimated at about 10 to 12 percent of the raw coal. ${ }^{5}$ In very rough numbers, about 20 percent of the liquid will be marketed as cresylic acid, about 50 percent as pitch, and about 30 percent used as oil to blend with diesel.

\section{Solid Products}

Char is the main product of mild gasification. During the PRU operation at WRI, the char yield was 36 to 43 percent of the raw coal. The char produced by inclined fluid-bed mild gasification of Wyoming coal was more reactive than any other fuel tested by Oak Ridge National Laboratory ${ }^{10}$ in a test program aimed at comparative evaluation. The char is a dust free, stable, low-sulfur $(0.4$ to 0.7 percent), high Btu (above 13,000 Btu/lb) fuel and can thus command a premium price over raw coal in the utility market. However, preliminary economic evaluations made by AMAX during Task 1 and the subsequent Stearns' study indicate that the char has to be upgraded and sold at considerably higher price to make the project economically viable.

Conversion of char to pure carbon was considered to be the most attractive alternative. Pure carbon can be marketed in three distinct markets:

$\begin{array}{ll}\text { Short Term } & \text { As Carbon Black for Rubber Compounding } \\ \text { Medium Term } & \begin{array}{l}\text { Partial Substitute of Petroleum Coke in the } \\ \text { Manufacture of Carbon Anodes }\end{array} \\ \text { Long Term } & \text { Premium Fuel for Power Production }\end{array}$

These three markets, originally targeted during Task 1, remain valid after limited testing of the carbon product produced from bench-scale reactors and the CTC PRU at Golden.

The first market, which requires extremely fine carbon powder, is economically most attractive but may require considerable marketing effort. The main advantage for the market will be a lower cost consistent feedstock.

The second market, which requires coarse carbon, is larger in size and although offers lower revenues, may be easier to penetrate because of AMAX's presence in the aluminum business. The addition of pure carbon will dilute the undesirable sulfur and metal impurities in petroleum coke. 
The process technology being developed produces a mix of these two products, as was observed in the PRU operation at Golden. Coarse carbon is the bed product from the fluidized-bed reactor and fine carbon is collected in the baghouse.

In the long term, though, the largest market for pure carbon will be as a premium fuel for power generation. ${ }^{11}$ It is in fine particulate form, free of sulfur, nitrogen, moisture, and ash impurities. It could be used in efficient heat engines being developed for mobile or stationary power plant operations. There will be no need for any scrubbers or a fuel preparation facility.

The CTC process being developed by AMAX consists of two steps, converting char to methane in an excess of hydrogen and decomposition of methane to carbon product and hydrogen gas for recycle. ${ }^{12}$ Under the merhanation conditions developed by AMAX, about a fourth of the weight of the char is not converted to methane. ${ }^{13}$ This residue product is very porous and can be upgraded to activated carbon. Laboratory tests indicate that this activated carbon is comparable in its performance to commercial products in terms of phenol absorption. ${ }^{14}$

Thus, activated carbon has been added to the product slate (Figure 1). It is a high-value product but with a limited market. It can add significantly to the economics of the project but cannot be relied on by the economic viability of the technology in the long term.

The spent char remaining after recovery of activated carbon still has fuel value, as do the fines collected in the drying and mild gasification operation, which amounts to about 8 to 10 percent of the raw coal feed, according to PRU experience. These will be used as fuels for power production as discussed below.

\section{Electricity}

The CTC process involves decomposition of methane at high temperatures in an indirectly heated reactor. In this process, there is a large amount of excess high quality thermal energy that can be easily converted to electricity, another value-added product. This energy is supplemented by the exothermic heat of methanation reaction which is recovered as steam, as well as steam produced during condensation of volatiles from the mild gasification reactor. The heat to the methane decomposition reactor will be provided by gasifying waste solid products (spent char and fines) and raw coal as required.

While some of the electricity will be used within the plant, an excess will be available for use by AMAX coal mines in Wyoming and for export. 


\section{PROCESS TECHNOLOGY}

Figure 2 shows a conceptual process flowsheet for conversion of Wyodak coal to the desired products. Coal is first dried to remove its moisture and then fed to the mild gasification reactor where most of its volatiles are removed. The volatiles are condensed as tar and oil, which are then upgraded to liquid products.

Char is converted to pure carbon and activated carbon in the CTC process. In the r.nethanation reactor, most of the char is converted to methane in an excess of hydrogen. This excess hydrogen is mostly recovered in a membrane gas separation unit and recycled. The methane-rich gas goes to the carbon formation reactor where it is cracked to produce carbon product and hydrogen gas for recycle. Heat is provided to the carbon reactor by heat pipes, which are heated by burning a fuel gas produced in a gasifier.

Recovered heat and steam are used to produce electricity in the power plant.

The flowsheet can be broken down into four areas for general technical evaluation as presented in this section.

\section{Drying and Mild Gasification}

The inclined fluid-bed mild gasification technology developed by WRI utilizes a shallow plug flow crosscurrent fluid-bed reactor. In this system, the coal is rapidly devolatilized in a recirculating stream of make gas, producing very reactive char and heavy pitch. To minimize water and oxygen contamination, the raw coal is first dried in a thermal dryer (Belle Ayr plant) to about 10 percent moisture and then in an inclined fluid-bed dryer to about 1 percent moisture content before entering the mild gasification reactor. The drying step has been demonstrated very well in the PRU operation at Laramie.

While the PRU at Laramie was operated continuously for up to 5 days, problems were encountered with the electric powered gas circulation heaters. The problem was sorted out to be due to carbon deposition on the heater elements. Gas analysis indicated significant concentrations of methane, which is prone to crack at higher temperatures, based both on thermodynamic analysis as well as practical experience gained in the two PRUs of the present program.

To overcome this problem, the original idea of having an AFBC heating the recycle gas indirectly in tubes was abandoned. It is now planned to burn the make gas and recycle the combustion products directly to the drying and mild gasification reactors.

This modification to the technology will reduce maintenance costs for cleaning the heat transfer tubes and eliminate the expense of the tubes, as well as eliminate 


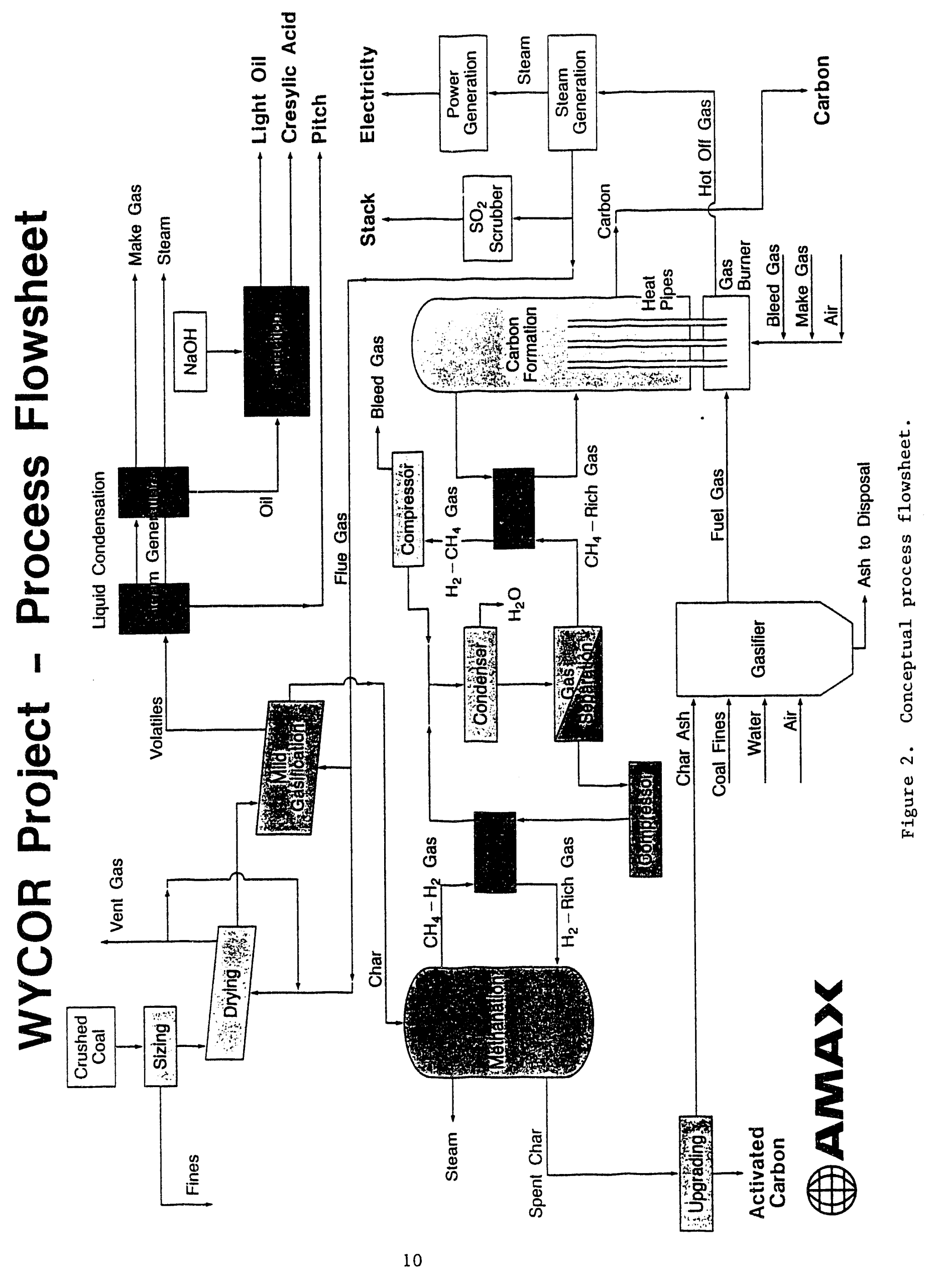


the need of mist eliminators in the make gas condensation train. Substitution of an AFBC by simple gas combustors also results in cost savings.

This approach is also being used in the Encoal mild gasification project. $^{15}$ The mild gasification PRU at the University of North Dakota Energy and Environmental Research Center (UNDEERC) of Grand Forks, North Dakota, also operates its carbonizer with combustion products. ${ }^{16}$ Thus, the technical risk is minimized by this approach.

Comparative reactivity tests performed at the bench scale at Amax R\&D have indicated that the char produced from Wyoming subbituminous coal is more reactive than any other char evaluated. This is probably due to the shallow bed reactor from which vapors are removed quickly before they get a chance to crack on char particles and plug the pores. For the same reasons, it is possible that this reactor design is more likely to yield high quality activated carbon than other designs (screw reactor or traditional fluidized-bed reactors).

\section{Condensate Recovery and Upgrading}

Simple air and water cooled condensers (made from large diameter pipe) were used in the mild gasification PRU at WRI, primarily to save cost. However, their operation was problematic. They were frequently plugged by condensed and solidified tar due to lack of a proper temperature control mechanism. For the same reason, there was no condensation selectivity, and a mixture of tar, oil, and water condensed in all condensers and the electrostatic precipitator (which was installed to collect a light oil fine mist). Of course, there was some trend for heavier fractions to be condensed and collected earlier in the circuit.

To overcome this problem, the design of the condensation train has been modified based on Parsons' experience and the experience from the mild gasification PRU currently under operation at UNDEERC. Amax R\&D is part of that project team.

In the proposed design, high efficiency, high-temperature cyclones will be used to remove particulates so that all the pitch product will be collected as clean pitch. A venturi scrubber will be used to condense heavy high-boiling point pitch, which will be recycled through a heat exchanger to reject heat. Under these conditions, the pitch will not be contaminated by lower boiling point oil or water, and its oxygen content may be lowered and coking index increased by the heat treatment that it will undergo in the recycle loop.

The gas exiting the pitch scrubber will be cooled in an oil absorption tower with recirculating oil, which will also pass through a heat exchanger. This oil will then be treated with caustic to recover cresylic acid. The remaining oil will be used as a fuel supplement to be blended with diesel fuel. 


\section{Char-to-Carbon Process}

When Stearns-Roger performed the preliminary feasibility study in 1988, two possible processes were evaluated for recovering pure carbon from char. The BEACON process developed by TRW with DOE funding relies on $\mathrm{CO}_{2}$ gasification of coal to produce $\mathrm{CO}$, which is then decomposed by the Boudard reaction to produce carbon and $\mathrm{CO}_{2}$ for recycle. The HYDROCARB process developed by Brookhaven National Laboratory relies on hydrogasification of coal to produce methane, which is then cracked at higher temperatures to produce carbon and hydrogen for recycle. It was concluded that the methane route was significantly superior in terms of technical feasibility and probable cost. ${ }^{2}$

However, the scheme proposed by HYDROCARB of recirculating alumina balls from one reactor to the other to conserve heat was considered impractical. Also, problems were anticipated in utilizing moving-bed reactors because of the highly exothermic and endothermic nature of the reactions.

The conceptual flowsheet selected for economic evaluation consisted of a fluidized-bed reactor for methanation of char and a traditional thermal black type reactor (two refractory filled chambers in tandem) for decomposition of methane. Thermal black reactors have been used, and are currently in commercial use, for production of carbon black by cracking methane (natural gas). Typically, methane passes through the hot reactor (initially at about $2,800^{\circ} \mathrm{F}$ and cooling it to about $2,200^{\circ} \mathrm{F}$ ) where it is cracked into carbon and hydrogen. The exit gas is cooled by water sprays, carbon is filtered in baghouses, and the gas (mixture of hydrogen product and uncracked methane) is burned in the second reactor to heat it from $2,200^{\circ} \mathrm{F}$ back up to $2,800^{\circ} \mathrm{F}$. After a few minutes of production or heating, the reactors are switched to the other cycle.

The yield of carbon from thermal black reactors is usually around 50 percent, about 25 percent loss due to unconverted methane and about 25 percent due to carbon left on the refractory bricks. Both of these are burned, along with the hydrogen produced during cracking, to supply the process heat requirement.

In an effort to improve the yield of carbon. Amax R\&D conceived and developed an indirectly heated continuous reactor process for decomposition of methane and other hydrocarbons to produce pure carbon and hydrogen. A patent application has been filed. ${ }^{17}$

The process operates at lower temperatures $\left(1,600\right.$ to $\left.1,800^{\circ} \mathrm{F}\right)$ than traditional thermal black or furnace black processes, which operate at 2,200 to $2,800^{\circ} \mathrm{F}$. Thus, the energy requirements are at a lower temperature and can be provided indirectly through metallic tubes permitting complete combustion of a lower grade fuel on the heat supply side. The lowering of the methane decomposition temperature was made possible by operating at 50 to 100 psia pressure, compared to the traditional process operating at ambient pressure. 
This operating pressure, however, is not a problem since the methane is formed from char at higher operating pressures. The research effort during performance of Task 3 led to development of process conditions which are less severe than commonly used for this step. In AMAX's CTC process, the char is converted to methane at about $1,400^{\circ} \mathrm{F}$ and 300 psia, while the traditional hydrogasification or coal gasification reactors operate at much higher temperatures and pressures. This is made possible by using a very reactive char, an excess of hydrogen, and accepting incomplete conversion. The unreacted char is upgraded to activated carbon as described in a patent application. ${ }^{18}$

During design of the 50 pound/hour CTC PRU, it was realized that closeness of temperature and pressure conditions in the methanation and carbon reactors $\left(1,400^{\circ} \mathrm{F}, 300\right.$ psia and $\left.1,800^{\circ} \mathrm{F}, 100 \mathrm{psia}\right)$ would diminish the thermodynamic driving force, limiting one pass conversion efficiency and, therefore, requiring a large amount of hydrogen to be recycled. To overcome this shortcoming, a membrane was included in the flowsheet to provide crude separation of methane (which goes to the carbon reactor) and hydrogen (which goes to the methanation reactor). A patent disclosure has been submitted to DOE and a patent application will be filed by AMAX. $^{19}$

Both the methanation and carbon reactors for the PRU were designed as fluidized-bed reactors. The methanation reaction is highly exothermic and proper fluidization is required for temperature control. A fluidized-bed carbon reactor full of carbon seed particles allows formation of both fine and coarse carbon by homogeneous and heterogeneous reactions, which were observed during benchscale tests. ${ }^{14}$ As discussed earlier, process heat will be provided through heat pipes in the PDU and CDP, but in the PRU, glow bars enclosed in Incoloy muffle tubes were inserted in the bed.

The detailed results from the CTC PRU operation are presented in the topical report. ${ }^{6}$ In summary, the methane reactor performed satisfactorily, and its performance can be further improved by a better feeding and discharging system (screws instead of J-valves). The membrane unit performed extremely well, requiring no maintenance over the one year period of operation.

The carbon reactor, while proving the concept of producing both coarse and fine carbon, did not perform well mainly due to materials of construction (of the heating tube) limitations. Scaling, erosion, and corrosion of the fins and tubes were observed. These caused poor conversion efficiency, contamination of the product, and finally shutdown of the operation due to safety concerns.

\section{POWER PRODUCTION AND WASTE DISPOSAL}

It should be appreciated by an exarnination of Figure 2 that the process does not require any expensive chemicals because hydrogen is produced and recycled within the CTC process loop. The key to success is then energy management. 
In the drying and mild gasification section of the plant, the make gas produced during mild gasification contains enough fuel value to supply the process heat requirements. Some dry coal and char fines collected from these operations are available as fuel. Also, the energy released during condensation of volatiles is recovered as low quality steam.

In the CTC section of the plant, methanation reaction is highly exothermic, and this energy is recovered as steam. The carbon formation reaction is endothermic, and the heat pipes supplying the heat to this reactor have to be heated with clean hot gas to avoid materials of construction problems. This hot off gas leaves the system at a very high temperature, $2,300^{\circ} \mathrm{F}$ or so, and contains a large amount of unutilized thermal energy.

It is proposed to harness all the available energy as steam to produce electricity. After supplying all the process plant needs, the project will produce surplus power for use by AMAX coal mines and for export. This situation is not unusual, and coal and petroleum refineries (such as SASOL in South Africa and Huls in Germany) have huge power plants associated with their chemical plants.

The heat pipes in the carbon reactor are heated by combustion of a clean fuel gas produced by a gasifier, as shown in Figure 2. The gasifier is fed with solid waste products such as coal and char fines, as well as spent char. Additional raw coal is to be used as required. The ash from the gasifier will be disposed of as a backfill for the mine. Any aqueous or organic waste from the plant will also be processed in the gasifier to recover the fuel value. A tail-gas limestone scrubber will be used to control sulfur emissions, and the resulting sludge will be combined with the ash for disposal.

Thus, there will be no liquid effluent from the plant. There will be only two gas stacks, one from the drying/mild gasification section and one from the CTC/power plant section. Both of these will emit combustion products normally emitted from coal-fired power plants. Similarly, the only solid wastes will be fly ash and gypsum sludge.

\section{AREAS REQUIRING FURTHER WORK}

The proposed 1,000 ton/day commercial demonstration plant considered in this study will basically consist of two parts, a process plant and a power plant. The technical evaluation presented above suggests that the following additional work may be required in the two areas to enhance the commercialization potential of the technology.

In the work done to date on the project, very little attention has been paid to the power plant. It has been assurned that power plant design, construction, and operation are standard commercial practice. However, a study by an appropriate 
engineering company will help in improving the overall energy efficiency of the plant and thereby the net power production. This study will also provide a more reliable cost estimate for the power plant. Two areas that need to be studied in particular are:

- Utilization of heat in combustion gas at $2,300^{\circ} \mathrm{F}$ for power production.

- A gasifier that can be fed with a variety of solid anrd liquid fuels and in which sulfur is possibly captured before the clean gas is burned to heat the heat pipes.

In the process plant section, there are several areas which need to be studied further at a PRU and/or PDU scale. These include:

- Operation of the inclined fluidized-bed dryer and mild gasification reactor with combustion product produced by burning the make gas.

- Modification of the liquid condensate recovery system to include venturi pitch scrubber and oil absorber scrubber.

- Modification of the methanation reactor to include continuous feeding and discharging through screws and a longer residence time or staging of the beds.

While better and more expensive materials of construction can be used to make the heat pipe approach work and overcome the corrosion problem, the CTC PRU experience shows that scaling and erosion may still be a concern. This information was not available when the PDU or CDP design studies were performed. Thus, it is important that alternative carbon reactor designs should be investigated. The thermal black reactor design evaluated by Stearns-Roger will be a lower cost option. It can be modified by sor $: ?$ research and development to increase the product yield. Antother possibility will be to use a plasma reactor. 


\section{COMMERCIAL DEMONSTRATION PLANT PRELIMINARY DESIGN}

This chapter, prepared by Parsons, contains a synopsis of the design criteria and a description of the flowsheet.

\section{DESIGN CRITERIA}

The detailed design criteria for the 1,000 ton/day coal drying, mild gasification, and char-to-carbon circuits are found in Appendix A.

The basis for the process design has been test work conducted by Western Research Institute (WRI) in Laramie, Wyoming, the University of North Dakota Energy and Environmental Research Center (UNDEERC) in Grand Forks, North Dakota, and Amax Research \& Development Center (AMAX) in Golden, Colorado. The work included the construction and operation of process research units (PRUs) by WRI, UNDEERC, and AMAX on the scale of 100 pounds/hour of coal. The preliminary design of a 20 ton/day process demonstration unit (PDU) also introduced some concepts. Parsons has used the available data to prepare the design criteria for the 1,000 ton/day demonstration plant. In essence, this has meant the assumption that the feed rates to each phase of the operation will be 50 times the feed rate to the 20 ton/day PDU.

The source of the design criteria data is shown for each of the major process steps. Some of the information was assumed by Parsons, based on the experience of our experts in the field, and some was calculated using HYSIM and ASPEN computer software. When no source is shown, it is to be understood that the information was developed by Parsons.

The flow rates for the feed preparation are based on the assumption that the coal will be received at 10 percent moisture and delivered to the demonstration plant feed bins at a feed rate considerably higher than the normal processing rate. The feed coal will be handled in conventional steeply-inclined flexible wall conveyers and horizontal conveyers with trippers.

There are a number of bins and lock hoppers in the process, and these have been sized by Parsons in the same manner as for the PDU based upon best estimates of the necessary retention time. The sizes are, it must be stressed, estimates and subject to change when the PDU results become available.

Coal drying and mild gasification operating conditions are as shown in Appendix A.

Reactor sizing for the dryer and mild gasifier were scaled up from the PDU. The PDU sizes were developed by Tecogen. 
The recovery systems for pitch and oil are slightly modified from those used by Stearns and are considered similar to those developed at the University of North Dakota. Only one type of pitch will be produced because low ash pitch was observed during the PRU tests.

The char-to-carbon reactors conform to the 20 ton/day PDU design and data from the 100 pound/hour PRU operation. The char-to-methane reactor, a single bed in the PRU, is specified as a stacked bed in the PDU and in this design in order to get a better conversion than has been observed in the PRU. In the endothermic carbon formation reactor, the electric glow bars in the PPIU are replaced in order to reduce operating costs. Heat pipes containing sodium metal vaporizing and condensing at $2,000^{\circ} \mathrm{F}$ are the basis for a system offered by Tecogen for the PDU.

Separation of hydrogen and methane by means of a semipermeable membrane is employed in the AMAX PRU. These membranes are very costly, but a recent study indicates that the overall economics are significantly improved when the hydrogen recovery was reduced from 80 to 70 percent.

\section{Gasifier}

The gasifier is defined by what it is to do and will require a custom design based on technology developed for similar applications but requiring modification or adaption for this application. The fuel will be a water slurry of raw coal and, from the process, recovered fines and spent char.

Removal of ash from the gasifier gas is essential. All the ash entering the process comes to this point for disposal back to the mine. The particulate level must be satisfactory downstream for heat pipe heating and heat recovery. At this time, removal by cyclones is being assumed.

The gasifier will be blown with air for partial combustion for operation at about $1,700^{\circ} \mathrm{F}$ and the production of medium Btu gas. The $1,700^{\circ} \mathrm{F}$ gas will have enough heating value that when (about) stoichiometric air is added, the flame temperature will be about $2,900^{\circ} \mathrm{F}$ in the fire box where heat is supplied to the heat pipes for the carbon formation reactor. These heat pipes, with a surface temperature of about $2,000^{\circ} \mathrm{F}$, will be fouled by molten slag if ash is present in the fire box. The exit gas at about $2,300^{\circ} \mathrm{F}$ will be used for other process requirements and power generation.

A limestone slurry flue gas absorber will remove sulfur oxides from the final effluent gas before it is discharged to the atmosphere.

\section{Power Generation}

The steam system is a means for conserving energy associated with the process rather than a utility for the process. Steam production is at 850 psig with 
superheat to $950^{\circ} \mathrm{F}$. These steam conditions are selected as suitable for the demonstration plant and are those used in the Stearns' enthalpy balances issued in February 1990 . They are not set by process requirements and are subject to review. The steam and power system uses conventional technology whose innovation is its association with the process.

The exothermic char-to-methane reaction at $1,382^{\circ} \mathrm{F}$ with about $73 \mathrm{MMBtu} / \mathrm{hr}$ easily generates saturated steam, which is $541^{\circ} \mathrm{F}$ at about $855 \mathrm{psig}$, but the predominant heat source is the flue gas, which is at about $2,200^{\circ} \mathrm{F}$, after heating the carbon formation reactor via the $2,000^{\circ} \mathrm{F}$ heat pipes. A con'entional boiler train of successive coils generates most of the saturated steam, superheats all the steam, and preheats all the boiler feed water to recover heat from the flue gas to about $275^{\circ} \mathrm{F}$. Process heat warms deaerator feed water. Provision is made to direct intermediate flue gas to heat the mild gasifier and dryer. All the steam goes to a steam turbine driving a generator and exhausting to an air condenser. for export.

About 32 megawatts of power will be produced with 22 megawatts available

\section{Utility Systems}

Process water is assumed to be obtainable from on-site wells. Water required for boiler feed water makeup (say $3(3 \mathrm{gpm}$ ) is processed in demineralizers furnished for this project. Excess water condensed in coal drying operations is assumed to contain no significant amounts of hydrocarbons or sulfur. Potable water is assumed to be supplied by the mine system.

Propane is supplied from the mine system as required as fuel for the inert gas generator. It is assumed that no natural gas is available on site.

\section{General Facilities and Off Sites}

The entire facility is assumed to be located near the mine site and connected via a 2,000-foot roadway from the mine road. The area will be fenced and contain two one-level buildings. A tank farm will store one week's production of oil, pitch, and wastewater. A 1,000-ton limestone storage silo and a. 600-foot rail spur will also be provided.

\section{Process Configuration}

As discussed earlier, the process configuration is based on WRI test work, together with input from other sources which include the University of North Dakota, Stearns-Roger, and AMAX. Parsons has also used their experience with other pyrolysis/gasificatiorı plants of similar nature and size. 
There is no fluidized-bed combustor in the present flowsheet. Rather, there is a gasifier which will handle the various combustible streams ahead of the carbonforming reactor fire box.

\section{PROCESS DESCRIPTION}

The process scheme for the coal drying/mild gasification and char-to-carbon circuits is shown on the accompanying process flow diagram (Drawing No. R-01-FS01). The process flow diagram and material balance are included in Appendix $B$.

\section{Coal Drying/Mild Gasification C: icuit}

Wet coal (10 percent moisture) is received from existing AMAX coal storage silos and transferred by a steeply inclined flexible wall conveyor (2008) and a conventional conveyor equipped with a tripper (2009) which discharges the coal into one of two contiguous coal feed surge hoppers (2651).

The wet coal is then transferred, on demand, via rotary valves (2028) and screw feeders (2025) into two trains of Tecogen coal dryers (2501). These dryers are wider than their lensth, so each one is fed by five equally spaced feeders in order to ensure an evenly spaced charge. The wet coal is dried to 2 percent moisture and heated to $400^{\circ} \mathrm{F}$ using hot $485^{\circ} \mathrm{F}$ combustion gas in a fluidized bed.

The dried coal is then transferred by gravity via chutes (2602) equipped with rotary valves (2010) to two Tecogen mild gasifiers (2502), one per dryer. The rotary valves serve two purposes. They provide a seal between the two processes and they ensure continued even flow of the coal. The flow rate into the mild gasifiers is about 30 tons/hour ${ }^{\mathrm{b}}$ where it is contacted with hot combustion gas at $1,264^{\circ} \mathrm{F}$ in a $5^{\circ}$ inclined fluidized bed.

The hot char at $1,100^{\circ} \mathrm{F}$ drops into two pairs of hot char lock hoppers (2652) and is discharged by hot screw conveyors (2051) to two char-to-methane reactors (2551) in the char upgrading area.

The dryer off gas from the Tecogen coal dryers (2501) flows at 3,215 Mscf/h and $261^{\circ} \mathrm{F}$ through venturis (2801) and dryer dust scrubbers (1101) for particulate

a Four digit numbers in parentheses refer to tag numbers. The principal equipment is shown on the drawing. The tag numbers for all equipment, together with the quantities of each item, are provided in the accompanying equipment list.

b All tonnage and volume figures are total for all of the units involved. 
removal. The gas stream is cooled to $100^{\circ} \mathrm{F}$ and condensed water is removed and sent to a thickener (3301).

The cool dryer recycle gas is compressed from atmospheric pressure to 24.1 psig by a liquid ring compressor (1801). Compressed gas is supplemented with enough $1,275^{\circ} \mathrm{F}$ flue gas to bring the mixture to $485^{\circ} \mathrm{F}$ and recycled to the dryer. The gas vented in the compressor outlet balances the hot make-up addition plus the noncombustible gas evolved in the dryer.

Recycled thickener (3301) overflow is pumped and cooled, in a heat exchanger (1301), primarily to provide motive power in the venturi contactor (2801) but also to provide liquid for the liquid ring compressor (1801).

Net water production in both thickener (3301) overflow and underflow flows to a fines slurry tank (1904). Other feeds to this tank are solids from the mild gasifier cyclones (2203) and the knock down from the KO drum (1252), both of which are discussed below. Raw coal is also sent to the fines slurry tank (1904) for gasifier feed requirements.

The agitated product of the fines siurry tank (1904) is pumped by a positive displacement pump (1508) to the gasifier (1401), together with the exhaust from the MEA acid gas plant (0851). Medium Btu gas produced in the gasifier (1401) is joined by gas from the oil absorber tower $(1: 02)$ to feed the carbon formation reactor (2252), see below.

The off gas from the Tecogen mild gasifiers (2502) flows at about 3,000 $\mathrm{Mscf} / \mathrm{h}$ and $1,041^{\circ} \mathrm{F}$ through mild gasifier cyclones (2203) equipped with rotary valves for particulate removal. The gas is prevented from cooling and condensing by a jacket carrying hot flue gas which is en route to the mild gasifiers.

The gas then passes through pitch venturis (2802) and scrubbers (1103) where approximately 47 tons/day of pitch are removed and pumped to storage. A recycle pitch is pumped through a heat exchanger (1302) and provides the motive power for the venturi (2802).

Hot pitch from the scrubber bottom flows by gravity into the clean pitch storage tank (1901). The stored pitch is kept hot by use of steam from the heat exchanger (1302). The pitch is pumped (1505) into heated rail tank cars for shipment.

The overhead from the pitch loop scrubber $(1103)$ at $380^{\circ} \mathrm{F}$ goes to an oil absorber tower (1102). The discharge from this tower is light oil, about 150 barrels/day, which flows by gravity into a holding tank. The oil is then pumped through a venturi scrubber where it is contacted with recirculating caustic solution. Cresylic acids in the oil are extracted into the caustic solution as sodium cresylate. 
Discharge from the venturi goes through a packed column where the liquid (oil and aqueous caustic solution) are separated from the gas stream. The liquid then goes to a decant tank where the oil and sodium cresylate sre separated.

The oil is pumped to a storage tank (1902) for shipment, and the sodium cresylate/caustic solution is recycled to increase the sodium cresylate concentration. A bleed stream is removed from the sodium cresylate recirculation loop and sent to a storage tank (1905) prior to shipment. Part of the oil is recirculated back to the absorber tower through a heat exchanger (1303) in order to cool the gas and condense additional oil in the packed bed.

The gas from the oil absorber tower (1102) goes to a make-gas blower (1803) for delivery as fuel for the carbon formation reactor (2552) at a rate of about $3,000 \mathrm{Mscf} / \mathrm{h}$, joining with the product of the gasifier (1401), as described above.

Other utility support systems include instrument air compressor/dryer, dieseldrive emergency generator, water demineralization s;stem, inert gas generator (2804), and boiler feed water treating package (0802).

\section{Char-to-Carbon Upgrading Facility}

Char upgrading is a two step process. In the first step, hot char from the mild gasifier is contacted with hydrogen. The reaction of carbon with hydrogen yields methane.

$$
\mathrm{C}+2 \mathrm{H}_{2} \rightarrow \mathrm{CH}_{4}
$$

The second step in the process is a reverse reaction in which methane is thermally cracked, yielding pure carbon product, and hydrogen is recycled to the first step.

$$
\mathrm{CH}_{4} \rightarrow \mathrm{C}+2 \mathrm{H}_{2}
$$

The first step in char upgrading is performed in a char-to-methane (CTM) reactor, or char gasifier (2551), where 390 tons/day of hot char at $1,100^{\circ} \mathrm{F}$ is fed into the reactor by hot screw conveyors (2051) from the lock hoppers (2652). The material is fluidized by a recycle gas stream consisting of hydrogen, methane, and impurities. The composition of the gas stream is shown in the design criteria (Appendix A).

The char gasifier (2551) operates at $1,400^{\circ} \mathrm{F}$ and $310 \mathrm{psig}$. The reaction is exothermic. The heat of reaction is sufficient to bring the components to the reaction temperature, but both char and recycle gas are preheated to improve the reaction kinetics. The heat of reaction is removed by generating steam at about 100,000 pounds/hour to control bed temperatures. Off gas from the reactor is 
passed thiough cyclones (not shown on the flowsheet) where most of the solids are removed from the gas stream. The cyclone underflow is returned to the reactor.

The solid discharge from the gasifier, termed "spent char", is fed to the activated carbon circuit where shaking concentrating tables (2255) separate the activated carbon from the waste, which is heavier. The activated carbon is filtered in the Shriver press (2803) and then dried in a tray dryer (2862) and drummed for shipment. The slurry is burned in the gasifier.

The CTM reactor (2551) off gas passes through a heat exchanger (1351) and venturi (2863) prior to entering a scrubber/separator (1254). The off gas then passes through (a) a cooler (1352), (b) MEA acid gas absorber, (c) preheater to about $200^{\circ} \mathrm{F}(1356)$, and then (d) the primary membrane (2853). Here, in the membrane (2853), hydrogen and methane are separated and the hydrogen is returned to the CTM reactor (2551) via a heat exchanger (1358), compressor (1851), another heat exchanger (1351), and CTM start-up heater (1452).

Conversion of the methane from the primary membrane (2853) is accomplished in fluidized-bed carbon formation reactors (2552), of which there are four in parallel, at $1,650^{\circ} \mathrm{F}$ and 100 psig.

This feed gas is preheated to $1,200^{\circ} \mathrm{F}$ in a feed effluent exchanger (1353) prior to entering the carbon black reactor (2552). The pressure of the gas is reduced across a let-down valve located upstream of the heat exchanger. This pressure reduction favors the chemical thermodynamic equilibrium for carbon formation.

The heat for the endothermic carbon formation reactors (2552) is supplied continuously by vertical 4 -inch heat pipes at $2,000^{\circ} \mathrm{F}$. In the section of the pipe that is within the reactor, sodium metal condenses. It (the sodium) flows down to the lower end of the pipe, which extends into the fire box below, where it is evaporated. The initial flame temperature in the fire box is about $2,900^{\circ} \mathrm{F}$ and the flue gas leaves at about $2,300^{\circ} \mathrm{F}$.

The carbon black reactors (2552) are equipped with integral cyclones and "J"valves to discharge the fine carbon black from the reactor bed, or from the baghouse (2853), which separates carbon black from the cooled effluent gas. The carbon black proceeds through lock hoppers (2655) into a screw feeder (2054) and final storage bin (2659), screw feeder (2059) and bagging, pelletizing and wrapping plant (3851) for sale.

The finest grade of carbon black will be that carried over in the gas and separated in the baghouse (2853). The other product will be drawn down from the top of the fluidized bed and have a larger particle size. If withdrawn from the bottom of the bed, it will be even coarser. The product from the baghouse will be 
agglomerated before bagging. The carbon black from the carbon black reactors will not require agglomeration.

The carbon formation reactor (2552) produces a finished high quality carbon black product, which is handled as described above, and a dusty exhaust, which is cooled in the feed effluent exchanger (1353) and separated from the finest carbon black in the dust collecting baghouse (2853). The clean gas from the baghouse (2353) passes through three heat exchangers $(1356,1361$, and 1354) and a compressor (1852) before being joined with the CTM reactor exhaust, which feeds the venturi (2863), see above.

Heat supply to the carbon formation heater/heat pipe unit (1451) is supplied from two sources. First, all of the downgraded solid materials collected in the overall process (coal fines, char fines, spent char, and activated carbon tails), plus raw coal as required, are pumped from the slurry tank (1401) and burned in the gasifier (1401) to produce a medium Btu content fuel gas at a temperature of about $1,700^{\circ} \mathrm{F}$. Fly ash is removed from the fuel gas in hot, high efficiency cyclones.

Next, the fuel gas, plus make gas from the mild gasification circuit and bleed gas from the char-to-carbon circuit, is combusted with air to generate a flame temperature of about $2,900^{\circ} \mathrm{F}$ in the carbon formation heater. Heat is transferred to the vaporization end of the heat pipes operating at about $2,000^{\circ} \mathrm{F}$, and exit gas from the heater at about $2,300^{\circ} \mathrm{F}$ goes to the power generation system boiler (0853).

A limestone slurry flue gas scrubber (0857) to remove sulfur oxides from the total effluent is installed on the boiler (0853) vent. Limestone is fed to the flue gas scrubber (0857) via a screw feeder (2030). Upstream, hydrogen sulfide from the MEA plant (0851) is injected into the gasifier to react, in due course, with the limestone.

A purge membrane (2854) recovers hydrogen from gas which is bled from the circuit to remove net $\mathrm{N}_{2}$, etc., evolved from the coal. It is similar to the primary membrane (2853). The net purge gas is additional fuel for the carbon formation reactor.

\section{Power Generation}

The power plant is similar to a contemporary power plant with a gasifier but with some differences.

In a typical design with a gasifier, the gas is cooled to permit sulfur removal. Some steam is generated in cooling the gas and a quench step removes entrained ash. The gas is burned in a gas turbine generator where the high level heat (above $2,000^{\circ} \mathrm{F}$ ) is converted to mechanical power with a high efficiency Brayton cycle. The hot turbine effluent generates more steam. The steam pressure is probably 1,500 psig or higher. 
In this installation, the high level heat is used in the process, so the gas turbine is omitted. The typical water walls of the gasifier are replaced by thick refractory because here it is essential that the initial heat recovery be in the process. This process requires transfer of hot gas to the second stage of combustion, so $\mathrm{SO}_{\mathrm{x}}$ is removed from the final flue gas. Efficient cyclones are included to remove ash from gas out of the gasifier.

Non-slagging ash systems typically have 10 percent of the carbon in the ash, and fuel requirements assume the same in this gasifier.

While the basic technology is available, this gasifier will be of custom design.

The temperature levels will permit higher steam pressure, 1,500 psig or higher, instead of the proposed 850 psig. With the uncertainty of the demonstration plant removed by its successful operation, subsequent plants will probably use higher pressure.

The value of the excess power can probably be set at the cost of purchased power to the AMAX mine, which can use most or all of it.

\section{PRODUCT YIELD AND POWER EXPORT}

The following is a listing of the net stream yields from the total plant without market values. The annual on-stream time used in the operating cost table is $\mathbf{3 3 3}$ days. The net M.G. make gas, 161 tons/day, is totally usec' for fuel and does not appear as yield. The activated carbon yield corresponds to an estimated rate of 10,000 tons/year.

The generator produces $32 \mathrm{MW}$ of electric power, of which $1 \mathrm{MW}$ is used for the air condenser and other internal needs, giving a power plant net output of 31 MW. The $9 \mathrm{MW}$ used in the coal processing plant is not charged as an operating cost, so the net $22 \mathrm{MW}$ is shown below. Most or all can be used in the AMAX mining operation, so it is reasonable to value all the power at the purchase cost of power to the mine, namely $\$ 0.055 / \mathrm{kWh}$.

\section{Yields Tons/Day Tons/Year MW}

$\begin{array}{lrr}\text { Pitch } & 47 & 13,200 \\ \text { Oil } & 16 & 5,800 \\ \text { Cresylic Acid } & 10 & 3,700 \\ \text { Activated Carbon } & 30 & 10,950 \\ \text { Carbon Black } & 220 & 80,200\end{array}$

Electric Power 


\section{COST AND REVENUE ESTIMATES}

This section presents the estimated capital cost, operating and maintenance costs, and operating revenues for the 1,000 ton/day commercial demonstration plant.

\section{CAPITAL COST}

The capital cost estimate prepared for the 1,000 ton/day commercial demonstration plant includes the cost of engineering, design, equipment and materials procurement, construction, calibration, and project management from project award to the engineering company to commissioning and start-up of the project facilities. Accuracy of the cost estimate is considered to be plus or minus 30 percent. The estimated total plant capital cost is $\$ 169$ million, which includes a contingency of about $\$ 26$ million.

\section{Assumptions}

The capital cost estimate is based on locating the plant at an existing AMAX coal mine site near Gillette, Wyoming, and on the following assumptions:

1. The construction site is clear and level with no underground or aboveground obstructions.

2. There is an adequate supply of qualified and experienced craftsmen in the area.

3. There is an easy means of ingress and egress for the craftsmen, equipment, and materials and weather conditions are not expected to unduly affect productivity.

4. Utilities and other support facilities are available at the battery limits in suitable conditions and adequate quantities.

5. All cost estimates are based on 3rd quarter 1991 prices. All cost estimates are expressed in United States currency and are based on United States procurement.

\section{Elements in the Capital Cost}

Elemients considered in the capital cost estimate to arrive at the total plant capital cost include major purchased equipment items, building and structures, bulk materials, electrical, instrumentation, direct labor costs, indirect costs, sales taxes, special site considerations, construction management, home office engineering, and contingency factor. 
The capital cost estimate was made by first determining the purchased cost of the major equipment. A major equipment factoring method consisting of applying known installation factors to the equipment cost on an item by item basis was used to estimate the constructed equipment cost. Special site features such as an access road, sales tax on equipment and materials, and construction management fees were then added to the constructed cost to arrive at the total field cost. A percentage factor for designed engineering was then applied to the field cost to arrive at the plant cost. Finally, another percentage factor for contingency was applied to the plant cost to arrive at the total plant capital cost.

\section{Major Equipment}

Major equipment includes all machinery used in the completed facility such as unit operation packages, tanks, vessels, rotating machinery (for example, generators, compressors, turbines, and pumps), boilers, heat exchangers, screens, water treatment packages, etc. Small pieces of equipment such as chutes, sumps, and hoists are not included in this category. The equipment list was derived from the process flow diagrams, and then process specification and data sheets were prepared for each piece of major equipment. A listing of the major equipment and partial specifications and sizing information are shown in Table 1.

Each equipment item was then priced by Parsons using either informal vendor quotes, Parsons in-house pricing, or other experience and factoring methods to adjust for equipment size and/or materials of construction. The cost of any rail or truck freight charges from point of purchase to the construction site is also included. A tabulation of equipment costs is shown in Table 2.

\section{Installation Factor}

Items included in the installation factor are the direct materials, direct labor, and indirect costs necessary to construct and install the equipment. The installation factors used in this report are based on similar factors used in the original Stearns report.

Direct materials include:

1. Bulk materials such as concrete, rebar, plate work, conduit, wire, etc.

2. Instrumentation items such as valves, sensors, interfaces, process control computers, displays, etc.

3. Process piping, fittings, hangers, supports, etc.

4. Building related items such as process buildings, control room, equipment support structures, structural steel, etc. 
Table 1. Major Equipment List and Description

No

Equipment Name

0851 Acid Gas MEA Absorption

0854

0852

0853

0855

0856

0857 Limestone Flue Gas Scrub

1101

1102

1103

1251

1252

1253

1254

1255

1256

1301

1302

1303
Methane Reactor Cooling System

BFW Treating Package

Boilers

Deaerator Package and BFW Pumps

Steam Turbine and Generator

Dryer Dust Scrubber

Oil Absorber Tower

Pitch Loop Scrubber

Membrane Feed KO Drum

Hydrogen Comp KO Drum

MTM Comp KO Drum

Scrubber Separator

Cresylic Acid Loop Separator

Cresylic Acid/Oil Decanter

Scrubber Loop Cooler

Pitch Loop Cooler

Recycle Oil Cooler
No.

$80 \mathrm{gpm}$ circulation rate of MEA, $4,800 \mathrm{lb} / \mathrm{hr}$

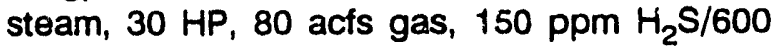
ppm $\mathrm{CO}_{2}, 310$ psig, $10 \mathrm{ft}$ dia. $\times 45 \mathrm{ft}$ Tा with absorber, regen., pumps, exch. etc.

$123,000 \mathrm{lb} / \mathrm{hr}$ with team drum, 3 pumps at 20 $\mathrm{HP}$ and $325 \mathrm{gpm}, 8$ coils at $350 \mathrm{ft}$ long $\times 5 \mathrm{ft}$ dia. with BFW package and deaerator

$900 \mathrm{gpm}$ condensate polishing, $100 \mathrm{gpm}$ makeup with $50 \mathrm{ft}$ dia. $\times 30 \mathrm{ft} \mathrm{H}$ tank

4 at $125,000 \mathrm{lb} / \mathrm{hr}$ at $860 \mathrm{psig}$

$500,000 \mathrm{lb} / \mathrm{hr}, 10 \mathrm{ft}$ dia. $\times 20 \mathrm{ft}$ L, $50 \mathrm{psig}$ at $300^{\circ} \mathrm{F}$ with stripping tower, 2 at $350 \mathrm{HP}$ at 40 $\mathrm{gpm}$ at $920 \mathrm{psig}$

$450,000 \mathrm{lb} / \mathrm{hr}, 860 \mathrm{psig}$ at $900^{\circ} \mathrm{F}$ steam to vacuum with conderiser and pumps, with $32 \mathrm{MW}$ generator

Alloy, sized to gasifier

CS, $11 \mathrm{ft}$ dia. $\times 9 \mathrm{ft}$ TT, cone bottom

2 CS, $13 \mathrm{ft}$ dia. $\times 12 \mathrm{ft} \mathrm{TT}$, cone bottom

CS, $7 \mathrm{ft}$ dia. $\times 9.3 \mathrm{ft} \mathrm{TT}$, cone bottom, 3,550 acfm at 300 psig at $100^{\circ} \mathrm{F}$

CS, $7 \mathrm{ft}$ dia. $\times 9.3 \mathrm{ft} \mathrm{TT}$, cone bottom, 7,050 acfm at $100 \mathrm{psig}$ at $100^{\circ} \mathrm{F}$

CS, $7 \mathrm{ft}$ dia. $\times 9.3 \mathrm{ft} \mathrm{TT}$, cone bottom, 6,150 acfm at 100 psig at $100^{\circ} \mathrm{F}$

CS, $9 \mathrm{ft}$ dia. $\times 15 \mathrm{ft} \mathrm{TT}$, cone bottom, 3,850 acfm at $100 \mathrm{psig}$ at $150^{\circ} \mathrm{F}$

1

CS, $7 \mathrm{ft} \mathrm{dia.} \times 10 \mathrm{ft} \mathrm{TT}$, cone bottom

1

CS, $7 \mathrm{ft}$ dia. $\times 10 \mathrm{ft} T$, cone bottom

2

CS, 6,750 MBtu/hr, AFS type

4

CS, $13,750 \mathrm{MBtu} / \mathrm{hr}$, double pipe

2

CS, 6,000 MBtu/hr, double pipe 


\begin{tabular}{|c|c|c|c|}
\hline No. & Equipment Name & No. & Description \\
\hline 1306 & Tempered Water Air Cooler & 1 & $\mathrm{CS}, 207,000 \mathrm{MBtu} / \mathrm{hr}, 2$ at $20 \mathrm{HP}$ \\
\hline 1351 & CTM F/E Exchanger & 2 & SS, $15,500 \mathrm{MBtu} / \mathrm{hr}$, double pipe \\
\hline 1352 & Membrane KO Water Cooler & 1 & CS and SS, 2,150 MBtu/hr, double pipe \\
\hline 1353 & CF Reactor F/E Exchanger & 4 & HP160, 13,640 MBtu/hr, double pipe \\
\hline 1354 & MTM Gas Comp. Condenser & 1 & $\mathrm{CS}$ and $1.25 \mathrm{Cr}, 3,000 \mathrm{MBtu} / \mathrm{hr}$, AFS \\
\hline 1355 & Scrubber Water Cooler & 1 & CS, 32,600 MBtu/hr, double pipe \\
\hline 1356 & Pro-Membrane Reheater & 1 & CS, 8,050 MBtu/hr, double pipe \\
\hline 1358 & Hydrogen Comp. Condenser & 1 & CS, 5,000 MBtu/hr, double pipe \\
\hline 1359 & Purge Membrane Cooler & 1 & CS, $250 \mathrm{MBtu} / \mathrm{hr}$, air cooled \\
\hline 1361 & MTM Gas Comp. Pre-Cooler & 1 & HP160, 10,000 MBtu/hr, double pipe \\
\hline 1401 & Gasifier & 1 & $\begin{array}{l}\text { CS with refractory lining, } 1,700^{\circ} \mathrm{F}, 400 \mathrm{psig} \text {, air } \\
\text { blown, } 370 \mathrm{MMBtu} / \mathrm{hr}\end{array}$ \\
\hline 1402 & Electric Heater Tank 1901 & 1 & $20 \mathrm{~kW}$ \\
\hline 1451 & CFR Gas Combustion Units & 4 & $\begin{array}{l}\text { CS with refractory lining, } 2,900^{\circ} \mathrm{F} \text {, In. } 617 \text { heat } \\
\text { pipes at } 2,000^{\circ} \mathrm{F}, 100 \mathrm{MMBtu} / \mathrm{hr}\end{array}$ \\
\hline 1452 & CTM Start-up and Gas Heater & 1 & Propane fired, $50 \mathrm{MMBtu} / \mathrm{hr}$ \\
\hline 1501 & Thickener Overflow Pump & 2 & $\mathrm{Cl}, 1,250 \mathrm{gpm}, 30 \mathrm{HP}$ \\
\hline 1502 & Coal Dust Slurry Pump & 1 & $\mathrm{Cl}, 25 \mathrm{gpm}, 1 \mathrm{HP}$ \\
\hline 1503 & Pitch Recycle Pump & 2 & $\mathrm{Cl}, 900 \mathrm{gpm}, 25 \mathrm{HP}$ \\
\hline 1504 & Oil Recycle Pump & 2 & $\mathrm{Cl}, 2,000 \mathrm{gpm}, 50 \mathrm{HP}$ \\
\hline 1505 & Pitch Product Pump & 1 & $\mathrm{Cl}, 10 \mathrm{gpm}, 1 \mathrm{HP}$ \\
\hline 1508 & Slurry Tk Discharge Pump & 1 & $\mathrm{Cl}, 50 \mathrm{gpm}, 2 \mathrm{HP}$ \\
\hline 1511 & Water Feed Pump & 1 & $\mathrm{Cl}, 14,000 \mathrm{gpm}, 350 \mathrm{HP}$ \\
\hline 1551 & Scrubber Pump & 1 & $304,4,400 \mathrm{gpm}, 350 \mathrm{HP}, 190 \mathrm{tdh}$ \\
\hline 1552 & Act. Carbon Feed Pump & 1 & $\mathrm{Cl}, 100 \mathrm{gpm}, 1 \mathrm{HP}$ \\
\hline 1555 & Act. Carbon Product Pump & 1 & $\mathrm{Cl}, 66$ gpm, $2 \mathrm{HP}$, pos. disp. \\
\hline 1556 & Act. Carbon Tails Pump & 1 & $\mathrm{Cl}, 35 \mathrm{gpm}, 1 \mathrm{HP}$ \\
\hline
\end{tabular}


Table 1. Major Equipment List and Description

(Continued)

№.

1557 Sodium Cresylate Circ. Pump

1558 Caustic Metering Pump

1801 Dust Scrubber Exhaust Comp.

1803 Make Gas Blower

1804 Gasifier Combustion Blower

1851 Hydrogen Reactor Gas Comp.

1852

1853

1901

1902

1903

1904

1906

1951

1952

1953

1954

1955

1956

2004

2008

2009

2010

Vent Gas Pickup Comp.

Pitch Storage Tank

Light Oil Storage Tank

Tempered Water Storage Tank

Fines Slurry Tank

Hydrogen Storage Tank

Act. Carbon Feed Tank

Act. Carbon Storage Tank

Act. Carbon Tails Tank

Oil/Cresylic Acid Feed Tank

Caustic Storage Tank

Cresylic Acid Product Tank

Hot Char Screw Conveyors

Coal Feed Conveyor

Coal Feed Distribut Conv.

Dryer Rotary Star Feeders
No.

1

1

4

2

2 o.

Description

$304,2,000 \mathrm{gpm}, 75 \mathrm{HP}, 100 \mathrm{tdh}$

304, 50 gpm, $1 \mathrm{HP}$, pos. disp.

CS, 21,000 acfm, 10 psi diff., $700 \mathrm{HP}$

CS, 42,800 acfm, 12 psi diff., 1,500 HP

CS, 5,000 acfm, 12 psi diff., $300 \mathrm{HP}$

CS, recip., 21,100 lb/hr, 30,200 acfm, $325 \mathrm{psig}$ at $400^{\circ} \mathrm{F}, 2,000 \mathrm{HP}$

CS, recip., $54,150 \mathrm{lb} / \mathrm{hr}, 41,350 \mathrm{actm}, 315 \mathrm{psig}$ at $375^{\circ} \mathrm{F}, 2,000 \mathrm{HP}$

1 CS, recip., 1,250 lb/hr, 2,150 scfm, $110 \mathrm{psig}$ at $400^{\circ} \mathrm{F}, 50 \mathrm{HP}$

1 CS, $15 \times 15 \mathrm{ft}$, cone bottom, $430^{\circ} \mathrm{F}$, with electric heater 1402

1 CS, $12 \times 12 \mathrm{ft}$, cone bottom

1 CS, $60 \times 60 \mathrm{ft}$

1 CS, $16 \mathrm{ft}$ dia. $\times 17 \mathrm{ft} \mathrm{H}$

1 Horizontal, Leased

1 CS, $14 \mathrm{ft}$ dia. $\times 16 \mathrm{ft} \mathrm{H}$, with agitator

1 CS, $12 \mathrm{ft}$ dia. $\times 14 \mathrm{ft} \mathrm{H}$, with agitator

1 CS, $10 \mathrm{ft}$ dia. $\times 12 \mathrm{ft} \mathrm{H}$, with agitator

1 CS, $12 \times 12 \mathrm{ft}$, cone bottom

$1304,5,000$ gallons, heated

1 CS, $12 \times 12 \mathrm{ft}$, cone bottom

$2304,1,040 \mathrm{lb} / \mathrm{hr}, 1,050^{\circ} \mathrm{F}, 6$ inch dia. $\times 25 \mathrm{ft} \mathrm{L}, 2$ HP

1 Rub. and CS, 24 inch W $\times 120 \mathrm{ft}$ L, $100 \mathrm{TPH}, 25$ HP

1 Rub. and CS, 24 inch $\times 100 \mathrm{ft}$, with trip, $10 \mathrm{HP}$

8 CS, $8 \times 10$ inches, 2 HP 
No.

2011

2025

2028

2029

2051

2052

2053 Fine Carbon Cooler Conv.

2054

2056

2057

2059

2060

2061

220

2203

2251

2252

2253

2254

2255

2256

2401

2451

2452
Equipment Name

Cyclone Rotary Valves

Dryer Screw Feeders

Dryer Discharge Star Valves

Gasifier Coal Feed Conv.

CTM Reactor Feed Screw

Spent Char Cooler Conv.

Medium Carbon Cooler Conv.

Carbon Star Feeders

Fine Carbon Product Screw

Medium Carbon Product Screw

Spent Char Screw Conveyor

Dried Fine Carbon Product Screw

Coal/Char Dust Collection

Mild Gasifier Off Gas Cyc.

CTM Reactor Primary Cyclone

CTM Reactor Sec. Cyclone

CF Reactor Cyclones

Carbon Baghouse

Gravity Separation Table

Fugitive Dust Collection

Gasifier Feed Slurry Agitator

A/C Feed Tank Agitator

A/C Product Tank Agitator
No.

Description

8 CS, $6 \times 8$ inches, $1 \mathrm{HP}$

8 CS, 6 inches $\times 20 \mathrm{ft} \mathrm{L}, 2 \mathrm{HP}$

8 CS, $8 \times 10$ inches, 2 HP

1 CS, 6 inch D $\times 15$ f L, $2 \mathrm{HP}$, variable speed

2304,6 inch $D \times 20 \mathrm{ft} L, 1,100^{\circ} \mathrm{F}$ at $320 \mathrm{psig}, 15$ tph, $2 \mathrm{HP}$, variable speed

1 CS, dual feed, 6 inches $\times 20 \mathrm{ft} L, 7.5 \mathrm{tph}, 30$ $\mathrm{Btu} / \mathrm{hr}, 700 / 100^{\circ} \mathrm{F}, 2 \mathrm{HP}$

1 CS, 4 feed points, 6 inches $\times 20 \mathrm{ft} L, 12.5 \mathrm{tph}$, $35 \mathrm{MBtu} / \mathrm{hr}, 500 / 100^{\circ} \mathrm{F}, 2 \mathrm{HP}$

1 CS, 4 feed points, 6 inches $\times 20 \mathrm{tt} \mathrm{L,} 12.5 \mathrm{tph}$, $60 \mathrm{MBtu} / \mathrm{hr}, 800 / 100^{\circ} \mathrm{F}, 2 \mathrm{HP}$

4 CS, $8 \times 10 \mathrm{ft}, 2 \mathrm{HP}$

1 CS, 6 inches $\times 20 \mathrm{ft} \mathrm{L,} 2 \mathrm{HP}$

1 CS, 6 inches $\times 20 \mathrm{ft}$ L, 2 HP

1 CS, 6 inches $\times 20 \mathrm{ft} L, 2 \mathrm{HP}$

1 CS, 6 inches $\times 20 \mathrm{ft} \mathrm{L,} 2 \mathrm{HP}$

1 CS, 20,000 actm, $25 \mathrm{HP}$

$8347,19,400$ acfm, $1,250^{\circ} \mathrm{F}$

2347,36 inch dia., 305 psig

2347,24 inch dia., 305 psig

$4 \quad 347,24$ inch dia., 100 psig

1 CS, 2,000 acfm, 100 psig at $500^{\circ} \mathrm{F}$

1 CS, $7 \mathrm{ft} \mathrm{W} \times 14 \mathrm{ft} \mathrm{L}, 3,200 \mathrm{lb} / \mathrm{hr}, 2 \mathrm{HP}$

1 CS, 20,000 acfm, $25 \mathrm{HP}$

1 CS, 20 inch dia., $15 \mathrm{HP}$

1 CS, 12 inch dia., $5 \mathrm{HP}$

1 CS, 10 inch dia., $3 \mathrm{HP}$ 


$$
\text { (Continued) }
$$

No.

2453

$2501 \quad$ IFB Dryers

2502

2551

2552

2601

2602 Dryer Discharge Chutes

2603 Gasifier Coal Feed Bin

2604

2625

2651

2652

2653

2654

2655

2657

2658

2659

2801

2802

2804
Equipment Name

A/C Tails Tank Agitator

IFB Mild Gasifiers

Methane Reactors

Carbon Reactors

Dryer Feed Chutes

Dryer Coal Feed Bin

Conveyor Transfer Chute

Char Feed Bins

Char Feed Lock Hoppers

Spent Char Lock Hoppers

Fine Carbon Lock Hoppers

Medium Carbon Lock Hoppers

Spent Char Storage Bin

Fine Carbon Bin

Medium Carbon Bin

Inert Gas Generator

Dryer Venturi Scrubber

Pitch Venturi Scrubber
No.

1

2

2

2

4

2

2

1

1

1

2

4

2

4

4

4

1

1

1

2

2

\section{Description}

CS, 10 inch dia., 3 HP

$C S, 30 \mathrm{ft} \mathrm{W} \times 10 \mathrm{ft} L \times 6 \mathrm{ft} \mathrm{H}, 4$ feed points each

$304,30 \mathrm{ft} W \times 10 \mathrm{ft} L \times 6 \mathrm{ft} H, 4$ feed points

304, $13 \mathrm{ft}$ dia. $\times 30 \mathrm{ft} \mathrm{TT,} 310 \mathrm{psig}$ at $1,400^{\circ} \mathrm{F}$, refractory lined, multi-stage

$304,23 \mathrm{ft}$ dia. $\times 18 \mathrm{ft} \mathrm{TT,} 100 \mathrm{psig}$ at $1,700^{\circ} \mathrm{F}$, refractory lined, $500^{\circ} \mathrm{F}$ shell

CS, $2 \mathrm{ft} \mathrm{W} \times 30 \mathrm{ft} L$

CS, $2 \mathrm{ft} \mathrm{W} \times 30 \mathrm{ft} \mathrm{L}$

CS, $12 \times 12 \mathrm{ft}$, cone bottom

CS, $12 \times 12 \mathrm{ft}$, cone bottom

CS, $1 \mathrm{ft} \mathrm{W} \times 12 \mathrm{ft} L$, rubber skirt

$C S, 2$ sections, $30 \mathrm{ft} L \times 15 \mathrm{ft} \mathrm{W} \times 15 \mathrm{ft} H$, with cone bottoms, vented to dust coll.

304, with auto valves, $9 \mathrm{ft}$ dia. $\times 13 \mathrm{ft} \mathrm{H}, 1,100^{\circ} \mathrm{F}$ at 310 psig

304 , with auto valves, $4 \mathrm{ft}$ dia. $\times 8 \mathrm{ft} \mathrm{H}, 800^{\circ} \mathrm{F}$ at $310 \mathrm{psig}$

CS, with auto valves, $2 \mathrm{ft}$ dia. $\times 4 \mathrm{ft} \mathrm{H}$, with cone bottoms $500^{\circ} \mathrm{F}$ at $100 \mathrm{psig}$

CS, with auto valves, $2 \mathrm{ft}$ dia. $\times 4 \mathrm{ft} \mathrm{H}$ with cone bottoms, $500^{\circ} \mathrm{F}$ at $100 \mathrm{psig}$

CS, $10 \mathrm{ft}$ dia. $\times 30 \mathrm{ft} \mathrm{H}$, cone bottom

CS, $24 \mathrm{ft}$ dia. $\times 48 \mathrm{ft} \mathrm{H}$, cone bottom

CS, $24 \mathrm{ft}$ dia. $\times 48 \mathrm{ft} \mathrm{H}$, cone bottom

Package, $100 \mathrm{HP}, 90,000$ scth, with compressor, dryer, receiver, and propane fuel storage

CS, $29,000 \mathrm{acfm}, 250 \mathrm{gpm}, 150 \mathrm{psig}, 100^{\circ} \mathrm{F}$

CS, 29,000 acfm, $900 \mathrm{gpm}, 150 \mathrm{psig}, 320^{\circ} \mathrm{F}$ 

(Continued)

No.

Equipment Name

2853

Primary Merr'trane System

2854

Purge Membrane System

2859 Carbon Agglomerizer

2860 Carbon Dryer

2861 Pressure Filter

2862 Activated Carbon Dryer

$2863 \mathrm{CH}_{4} / \mathrm{H}_{2}$ Venturi Scrubber

2864 Cresylic Acid Vent Scrub

3301 Coal Fines Thickener

3801 Carbon Packer, Bagger, etc.
No.

Description

1450 membrane units, 3 per vessel from Medal, Liquid Air

19 membrane units, 3 per vessel from Medal, Liquid Air

1 CS, pin mill type, $25 \mathrm{HP}$

1 CS, holo-flite screw, indirect stean heat

1 RFP, $66 \mathrm{gpm}$ at $15 \%$ solids, $4 \times 4 \mathrm{ft}$ plates, 24 plates

1 CS, tray dryer, 5 tph solids, steam heated

$1304,6,250 \mathrm{acfm}$ at $300 \mathrm{psig}$ at $525^{\circ} \mathrm{F}, 4,300$ gpm at $400 \mathrm{psig}$ at $100^{\circ} \mathrm{F}$

$1304,25,000 \mathrm{acfm}$ at $150 \mathrm{psig}$ at $200^{\circ} \mathrm{F}, 700 \mathrm{gpm}$ at 200 psig at $100^{\circ} \mathrm{F}$

1 CS, $20 \mathrm{ft}$ dia. $\times 10 \mathrm{ft}$ swd, with rake, drive, and OF launder, $2 \mathrm{HP}$

1 CS, 25 tph, auto fill and weigh, with shrink wrap pelletizer 
No.

0851

0854

0852

0853

0855

0856

0857

1101

1102

1103

1251

1252

1253

1254

$1 \overline{65}$

1256

1301

1302

1303

1306

1351

1352

1353

1354

1355

1356

1358

1359

1361

1401

1402

1451

1452

1501

1502

1503

1504

1505

1508

1511
Equipment Name

Acid Gas MEA Absorption

Subtotal Process Packages

Methane Reactor Cooling System

BFW Treating Package

Boilers

Deaerator Package and BFW Pumps

Steam Turbine and Generator

Limestone Flue Gas Scrub

Subtotal Power Generation

Dryer Dust Scrubber

Oil Absorber Tower

Pitch Loop Scrubber

Subtotal Columns

Membrane Feed KO Drum

Hydrogen Comp KO Drum

MTM Comp KO Drum

Scrubber Separator

Cresylic Acid Loop Separator

Cresylic Acid/Oil Decanter

Subtotal Vessels

Scrubber Loop Cooler

Pitch Loop Cooler

Recycle Oil Cooler

Tempered Water Air Cooler

CTM F/E Exchanger

Membrane KO Water Cooler

CF Reactor F/E Exchanger

MTM Gas Comp. Condenser

Scrubber Water Cooler

Pro-Membrane Reheater

Hydrogen Comp. Condenser

Purge Membrane Cooler

MTM Gas Comp. Pre-Cooler

Subtotal Heat Exchangers

Gasifier

Electric Heater Tank 1901

CFR Gas Combustion Units

CTM Start-up and Gas Heater

Subtotal Furnace and Heater

Thickener Overflow Pump

Coal Dust Slurry Pump

Pitch Recycle Pump

Oil Recycle Pump

Pitch Product Pump

Slurry Tk Discharge Pump

Water Feed Pump

\begin{tabular}{|c|c|c|c|}
\hline $\begin{array}{l}\text { No. } \\
\text { Items }\end{array}$ & $\begin{array}{l}\text { Equipment } \\
\text { Cost, } \$\end{array}$ & $\begin{array}{c}\text { Installation } \\
\text { Factor }\end{array}$ & $\begin{array}{r}\text { Installed } \\
\text { Cost, \$ }\end{array}$ \\
\hline 1 & $\frac{609,500}{609,500}$ & 1.6 & $\frac{1,023,960}{1,023,960}$ \\
\hline $\begin{array}{l}1 \\
1\end{array}$ & $3,936,500$ & 2.0 & $8,266,650$ \\
\hline 4 & $3,060,000$ & 1.8 & $5,783,400$ \\
\hline $\begin{array}{l}1 \\
1\end{array}$ & $\begin{array}{r}4,662,800 \\
\frac{1,000,000}{12,659,300}\end{array}$ & $\begin{array}{l}1.8 \\
1.6\end{array}$ & $\begin{array}{r}8,812,692 \\
1,680,000 \\
24,542,742\end{array}$ \\
\hline $\begin{array}{l}2 \\
2 \\
2\end{array}$ & $\begin{array}{r}73,000 \\
108,300 \\
101,500 \\
282,800\end{array}$ & $\begin{array}{l}1.8 \\
1.8 \\
1.8\end{array}$ & $\begin{array}{l}137,970 \\
204,687 \\
191,835 \\
534,492\end{array}$ \\
\hline $\begin{array}{l}1 \\
1 \\
1 \\
1 \\
1 \\
1\end{array}$ & $\begin{array}{r}18,900 \\
18,900 \\
18,900 \\
34,100 \\
22,000 \\
\underline{27,000} \\
139,800\end{array}$ & $\begin{array}{l}2.8 \\
2.8 \\
2.8 \\
2.8 \\
2.8 \\
2.8\end{array}$ & $\begin{array}{r}55,566 \\
55,566 \\
55,566 \\
100,254 \\
64,680 \\
\frac{79,380}{411,012}\end{array}$ \\
\hline 2 & 33,400 & 2.9 & 101,703 \\
\hline 2 & 167,200 & 2.5 & 438,900 \\
\hline 2 & 115,000 & 2.5 & 301,875 \\
\hline 1 & 366,000 & 2.0 & 768,600 \\
\hline 2 & 345,000 & 2.2 & 796,950 \\
\hline 1 & 181,000 & 2.5 & 475,125 \\
\hline 4 & $1,275,000$ & 1.9 & $2,543,625$ \\
\hline 1 & 33,000 & 2.9 & 100,485 \\
\hline 1 & 533,000 & 2.1 & $1,175,265$ \\
\hline 1 & 47,000 & 2.9 & 143,115 \\
\hline 1 & 76,000 & 2.9 & 231,420 \\
\hline 1 & 37,000 & 2.9 & 112,665 \\
\hline 1 & $\begin{array}{r}\frac{50,000}{3,258,600} \\
\text {. }\end{array}$ & 2.9 & $7 \frac{152,250}{7,341,978}$ \\
\hline $\begin{array}{l}1 \\
1\end{array}$ & $\begin{array}{r}3,000,000 \\
\text { Included }\end{array}$ & 1.6 & $\begin{array}{r}5,040,000 \\
0\end{array}$ \\
\hline 4 & $5,900,000$ & 1.8 & $11,151,000$ \\
\hline 1 & $\frac{600,000}{9,500,000}$ & 1.8 & $\frac{1,134,000}{17,325,000}$ \\
\hline 2 & 110,000 & 3.0 & 346,500 \\
\hline 1 & 5,000 & 3.0 & 15,750 \\
\hline 2 & 100,000 & 3.0 & 315,000 \\
\hline 2 & 128,000 & 3.0 & 403,200 \\
\hline 1 & 27,000 & 3.0 & 85,050 \\
\hline 1 & 5,000 & 3.0 & 15,750 \\
\hline 1 & 130,000 & 3.0 & 409,500 \\
\hline
\end{tabular}


(Continued)

\begin{tabular}{|c|c|c|c|c|c|}
\hline No. & Equipment Name & Items & Cost, $\$$ & Factor & Cost, $\$$ \\
\hline 1551 & Scrubber Pump & 1 & 130,000 & 3.0 & 409,500 \\
\hline 1552 & Act. Carbon Feed Pump & 1 & 500 & 3.0 & 1,575 \\
\hline 1555 & Act. Carbon Product Pump & 1 & 10,000 & 3.0 & 31,500 \\
\hline 1556 & Act. Carbon Tails Pump & 1 & 500 & 3.0 & 1,575 \\
\hline 1557 & Sodium Cresylate Circ. Pump & 1 & 39,000 & 3.0 & 122,850 \\
\hline 1558 & $\begin{array}{l}\text { Caustic Metering Pump } \\
\text { Subtotal Pumps and Drivers }\end{array}$ & 1 & $\frac{3,000}{688,000}$ & 3.0 & $2,167,200$ \\
\hline 1801 & Dust Scrubber Exhaust Comp. & 2 & 700,000 & 2.0 & $1,470,000$ \\
\hline 1803 & Make Gas Blower & 2 & $1,260,000$ & 1.8 & $2,381,400$ \\
\hline 1804 & Gasifier Combustion Blower & 2 & 310,000 & 2.0 & 651,000 \\
\hline 1851 & Hydrogen Reactor Gas Comp. & 1 & $2,000,000$ & 1.9 & $3,990,000$ \\
\hline 1852 & MTM Boost Gas Comp. & 1 & $2,000,000$ & 1.9 & $3,990,000$ \\
\hline 1853 & $\begin{array}{l}\text { Vent Gas Pickup Comp. } \\
\text { Subtotal Blowers and Compressors }\end{array}$ & 1 & $\frac{1,250,000}{7,520,000}$ & 1.9 & $\frac{2,493,750}{14,976,150}$ \\
\hline 1901 & Pitch Storage Tank & 1 & 58,800 & 1.9 & 117,306 \\
\hline 1902 & Light Oil Storage Tank & 1 & 25,000 & 1.9 & 49,875 \\
\hline 1903 & Tempered Water Storage Tank & 1 & 224,000 & 1.9 & 446,880 \\
\hline 1904 & Fines Slurry Tank & 1 & 47,400 & 1.9 & 94,563 \\
\hline 1906 & Hydrogen Storage Tank & 1 & Leased & 1.9 & 0 \\
\hline 1951 & Act. Carbon Feed Tank & 1 & 27,500 & 1.9 & 54,863 \\
\hline 1952 & Act. Carbon Storage Tank & 1 & 21,300 & 1.9 & 42,494 \\
\hline 1953 & Act. Carbon Tails Tank & 1 & 16,300 & 1.9 & 32,519 \\
\hline 1954 & Oil/Cresylic Acid Feed Tank & 1 & 17,000 & 1.9 & 33,915 \\
\hline 1955 & Caustic Storage Tank & 1 & 23,000 & 1.9 & 45,885 \\
\hline 1956 & $\begin{array}{l}\text { Cresylic Acid Product Tank } \\
\text { Subtotal Storage Tanks }\end{array}$ & 1 & $\frac{19,000}{479,300}$ & 1.9 & $\frac{37,905}{956,205}$ \\
\hline 2004 & Hot Char Screw Conveyors & 2 & 57,000 & 1.9 & 113,715 \\
\hline 2008 & Coal Feed Conveyor & 1 & 195,000 & 1.9 & 389,025 \\
\hline 2009 & Coal Feed Distribut Conv. & 1 & 119,000 & 1.9 & 237,405 \\
\hline 2010 & Dryer Rotary Star Feeders & 10 & 52,000 & 1.9 & 103,740 \\
\hline 2011 & Cyclone Rotary Valves & 8 & 70,000 & 1.9 & 139,650 \\
\hline 2025 & Dryer Screw Feeders & 10 & 194,000 & 1.9 & 387,030 \\
\hline 2028 & Dryer Discharge Star Valves & 10 & 52,000 & 1.9 & 103,740 \\
\hline 2029 & Gasifier Coal Feed Conv. & 1 & 19,400 & 1.9 & 38,703 \\
\hline 2051 & CTM Reactor Feed Screw & 2 & 260,000 & 1.9 & 518,700 \\
\hline 2052 & Spent Char Cooler Conv. & 1 & 130,000 & 1.9 & 259,350 \\
\hline 2053 & Fine Carbon Cooler Conv. & 1 & 130,000 & 1.9 & 259,350 \\
\hline 2054 & Medium Carbon Cooler Conv. & 1 & 130,000 & 1.9 & 259,350 \\
\hline 2056 & Carbon Star Feeders & 4 & 75,000 & 1.9 & 149,625 \\
\hline 2057 & Fine Carbon Product Screw & 1 & 30,000 & 1.9 & 59,850 \\
\hline 2059 & Medium Carbon Product Screw & 1 & 30,000 & 1.9 & 59,850 \\
\hline 2060 & Spent Char Screw Conveyor & 1 & 30,000 & 1.9 & 59,850 \\
\hline 2061 & $\begin{array}{l}\text { Dried Fine Carbon Product Screw } \\
\text { Subtotal Materials Handling }\end{array}$ & 1 & $\frac{30,000}{1,603,400}$ & 1.9 & $3,198,783$ \\
\hline 2201 & Coal/Char Dust Collection & 1 & 100,000 & 1.5 & 157,500 \\
\hline 2203 & Mild Gasifier Off Gas Cyc. & 8 & 440,000 & 1.8 & 831,600 \\
\hline
\end{tabular}


(Continued)

\begin{aligned} No. & \multicolumn{1}{c}{ Equipment Name } \\ 2251 & CTM Reactor Primary Cydone \\ 2252 & CTM Reactor Sec. Cyclone \\ 2253 & CF Reactor Cyclones \\ 2254 & Carbon Baghouse \\ 2255 & Gravity Separation Table \\ 2256 & Fugitive Dust Collection \\ & Subtotal Separation Equipment \end{aligned}

2401

2451

2452

2453

2501

2502

2551

2552

2601

2602

2603

2604

2625

2651

2652

2653

2654

2655

2657

2658

2659

2801

2802

2804

2853

2854

2859

2860

2861

2862

2863

2864

3301

3801
Gasifier Feed Slurry Agitator

A/C Feed Tank Agitator

A/C Product Tank Agitator

A/C Tails Tank Agitator

Subtotal Agitators

IFB Dryers

IFB Mild Gasifiers

Methane Reactors

Carbon Reactors

Subtotal Reactors

Dryer Feed Chutes

Dryer Discharge Chutes

Gasifier Coal Feed Bin

Dryer Coal Feed Bin

Conveyor Transfer Chute

Char Feed Bins

Char Feed Lock Hoppers

Spent Char Lock Hoppers

Fine Carbon Lock Hoppers

Medium Carbon Lock Hoppers

Spent Char Storage Bin

Fine Carbon Bin

Medium Carbon Bin

Subtotal Hopper, Chutes, Bins

Inert Gas Generator

Dryer Venturi Scrubber

Pitch Venturi Scrubber

Primary Membrane System

Purge Membrane System

Carbon Agglomerizer

Carbon Dryer

Pressure Filter

Activated Carbon Dryer

$\mathrm{CH}_{4} / \mathrm{H}_{2}$ Venturi Scrubber

Cresylic Acid Vent Scrub

Subtotal Other Process Equip.

Coal Fines Thickener

Carbon Packer, Bagger, etc.

Subtctal Miscellaneous

Final Totals for Major Equip.

\begin{tabular}{|c|c|c|c|}
\hline $\begin{array}{l}\text { No. } \\
\text { Items }\end{array}$ & $\begin{array}{l}\text { Equipment } \\
\text { Cost, } \$\end{array}$ & $\begin{array}{l}\text { Installation } \\
\text { Factor }\end{array}$ & $\begin{array}{l}\text { Installed } \\
\text { Cost, } \$ \\
\end{array}$ \\
\hline 2 & 34,000 & 1.8 & 64,250 \\
\hline 2 & 27,000 & 1.8 & 51,030 \\
\hline 4 & 136,000 & 1.8 & 257,040 \\
\hline 1 & 150,000 & 1.5 & 236,250 \\
\hline 1 & 12,700 & 1.8 & 24,003 \\
\hline 1 & $1,9 \frac{75,000}{1,949,400}$ & 1.5 & $3 \frac{118,125}{3,479,616}$ \\
\hline 1 & 14,100 & 2.0 & 29,610 \\
\hline 1 & 8,700 & 2.0 & 18,270 \\
\hline 1 & 5,100 & 2.0 & 10,710 \\
\hline 1 & $\frac{5,100}{33,000}$ & 2.0 & $\frac{10,710}{69,300}$ \\
\hline
\end{tabular}

2.3

$3,864,000$

$6,279,000$

$4,462,500$

$2,600,000$

2.3

1.7

1.9

$8,778,000$

$4,400,000$

$11,100,000$

1.6

1.6

55,600

60,000

450,000

5,300

329,200

420,000

55,000

30,000

44,000

32,000

240,000

240,000

$2,016,700$

1.8

1.8

1.6

1.8

2.2

2.4

2.4

2.4

1.8

1.8

1.8

520,000

160,000

200,000

2.0

2.4

2.4

$7,000,000$

330,000

51,000

150,000

580,000

57,000

200,000

55,000

$9,303,000$

1.8

1.8

1.2

1.7

2.0

1.9

2.4

2.4

120,000

470,000

590,000

1.8

1.7

$60,758,100$
$23,383,500$

93,408

93,408

113,400

850,500

8,904

622,188

970,200

138,600

75,600

110,880

60,480

453,600

$\underline{453,600}$

$4,044,768$

$1,092,000$

403,200

504,000

$13,230,000$

623,700

64,260

267,750

$1,218,000$

113,715

504,000

138,600

$18, \overline{159,225}$

226,800

838,950

$1, \overline{065,750}$

$120,939,972$ 
5. Electrical items such as local stations, motor cuntrol center, switch gear, distribution and supply facilities, etc.

Indirect labor includes the cost of wages of all field craft labor and the first level of supervision directly associated with construction of permanent plant facilities.

Construction indirects include labor benefits, burdens, insurance, payroll taxes, temporary facilities, staff supervision, construction equipment, small tools, and consumable supplies.

Also shown in Table 2, in addition to the equipment costs, are the individual equipment installation factors and a tabulation of the constructed equipment cost.

\section{Total Plant Capital Cost}

Table 3 is a final tabulation of the total plant capital cost of $\$ 169,045,000$. In addition to the equipment and installation costs previously discussed, other cost factors such as special site features, sales taxes, construction management fees, home office engineering fees, and contingency were used to arrive at the total. Due to different factors being used for the process plant (mild gasification and product upgrading) versus the power plant used for power generation, Table 3 shows individual tabulations for the process and power plants, as well as a total tabulation. Details of the additional cost factors are explained below.

\section{Access Road and Rail Spur}

Due to construction of this project at an established coal mine site, a number of special site-related items such as main railroad track, office space, maintenance facilities, shower and lockers, guard house, first aid room, employees parking, main access roads, and utility supply are not required.

Special items that are required include a limited amount of access road to the specific plant site on the mine property and a short rail spur of less than 200 yards.

\section{Sales Taxes}

A sales tax rate of 4.0 percent was applied against the total estimated value of the major equipment and bulk material and supplies.

\section{Construction Management}

Construction management fees are estimated at 5 percent of the constructed equipment cost. These costs are used to hire a construction management team that may be supplied by the design engineering company, the project sponsor (AMAX), or an independent consulting/management firm that specializes in providing 
this type of service. The team for a project of this size normally consists of 5 to 8 key people plus supporting team members that:

1. Expedite equipment delivery.

2. Inspect, inventory, and warehouse equipment, parts, bulks, and tools.

3. Supervise the construction labor.

4. Provide scheduling and cost control and maintain the critical path.

5. Purchase bulk materials.

6 Schedule subcontractors.

7. Essentially make sure that all construction activities go as planned.

Table 3. Summary of Total Plant Capital Costs

\begin{tabular}{|c|c|c|c|}
\hline Cost Items & $\begin{array}{l}\text { Process Plant } \\
\text { Costs, } \$ \\
\end{array}$ & $\begin{array}{l}\text { Power Plant } \\
\text { Costs, \$ }\end{array}$ & $\begin{array}{c}\text { Total } \\
\text { Costs, } \$\end{array}$ \\
\hline $\begin{array}{l}\text { Total Major Equipment Cost } \\
\text { Installation Cost }\end{array}$ & $\begin{array}{l}48,098,800 \\
48,298,300 \\
\end{array}$ & $\begin{array}{l}12,659,300 \\
11,883,400 \\
\end{array}$ & $\begin{array}{l}60,758,100 \\
60,181,800 \\
\end{array}$ \\
\hline Total Installed Cost & $96,397,100$ & $24,542,700$ & $120,939,900$ \\
\hline $\begin{array}{l}\text { Site Requirements } \\
\text { Sales Tax, Equip. \& Materials } \\
\text { Construction Management (5\%) }\end{array}$ & $\begin{array}{r}100,000 \\
2,891,900 \\
4,819,900 \\
\end{array}$ & $\begin{array}{r}736,300 \\
1,227,100 \\
\end{array}$ & $\begin{array}{r}100,000 \\
3,628,200 \\
6,047,000 \\
\end{array}$ \\
\hline Total Field Cost & $104,208,900$ & $26,506,100$ & $130,715,100$ \\
\hline $\begin{array}{l}\text { Home Office Engineering (10\% } \\
\text { Mild Gas., } 8 \% \text { Power) }\end{array}$ & $10,420,900$ & $2,120,500$ & $12,541,400$ \\
\hline Total Plant Cost & $114,629,800$ & $28,626,600$ & $143,256,500$ \\
\hline $\begin{array}{l}\text { Contingency ( } 20 \% \text { Mild Gas., } \\
10 \% \text { Power) }\end{array}$ & $\underline{22,926,000}$ & $\underline{2,862,700}$ & $25,788,600$ \\
\hline Total Plant Capital Cost & $137,555,800$ & $31,489,300$ & $169,045,100$ \\
\hline
\end{tabular}

\section{Home Office Engineering}

The home office engineering fee includes all costs associated with the process design, detailed engineering, procurement, business services, overhead, profit, and other expenses at the permanent home office location. Two percentage values were used in this estimate. For engineering associated with the process 
plant, a fee of 10 percent was used. For the power plant, a fee of 8 percent was used.

\section{Contingency}

The contingency factor accounts for uncertainty in the process flowsheet, some scope changes, and undeveloped design. As in the case of the engincering fee, two different percentages were used, 20 percent for the process plant and 10 percent for the power plant.

\section{Excluded Costs}

All remaining cost elements associated with a capital project of this type are excluded. These include the following:

1. All costs outside battery limits (OSBL) except the access road and rail spur. The estimate assumes utilities and other support services are already at the mine site. This project is not considered a greenfield site type project.

2. All owner's costs such as research and development, management, and supervision.

3. Commissioning and start-up costs.

4. Catalysts, chemicals, and start-up expendable supplies.

5. Scope changes outside that accounted for in the contingency allowance.

6. Cost of land, money, and finance charges.

7. Royalties and licensing fees.

8. Overtime or shift premiums to adjust and/or accelerate the project schedule.

9. Construction and environmental permits.

\section{OPERATING AND MAINTENANCE COSTS}

The direct operating costs were estimated on calculated costs for feedstocks, chemicals and supplies, utilities, disposal costs, and operating labor requirements. All costs were calculated from process consumption estimates based on the material balance and from typical AMAX rates and costs for labor, utilities, and supplies.

The operating costs are based on a 333 twenty-four hour days per year operation, which equates to a 90 percent on-stream factor. 
Annual maintenance costs, including labor and materials, were assumed to be 2.5 percent of the total plant capital cost of $\$ 169$ million, or $\$ 4.2$ million per year.

Both the direct operating and maintenance costs are summarized in Table 4, which equate to $\$ 11.06$ million per year. Individual elements of the direct operating costs are summarized in Table 5.

\section{Table 4. Summary of Annual Operating and Maintenance Costs}

\section{Cost Element}

Feedstocks

Chemicals and Supplies

Utilities

Disposal Costs

Maintenance

Operating Labor

Total
Cost $(\$ \times 1,000)$

2,081

171

533

45

4,200

$\underline{4,027}$

11,057

Feedstocks to the plant include sized and partially dried coal at 10 percent moisture fed to the mild gasification circuit dryer and fine run-of-mine coal at 30 percent moisture fed to the gasifier.

Chemicals and supplies include boiler feed water (BFW) chemicals and limestone used to control sulfur emissions. Other consumable supplies are expected to be minor and are included in the maintenance cost factor.

Utilities for the plant include electrical power, propane, and water. The electric power rate is assumed to be $\$ 0.055$ per $\mathrm{kWh}$, and since the gasifier and power generation capability of the plant is in excess of that required to run the plant, there is a net generation of excess power. The excess is treated as revenue, while that amount required to run the plant is subtracted from the gross power output and considered as free power to the plant. Table 5 shows the plant power requirement and also reflects a zero annual cost. Plant power consumption per equipment item is shown in Table 6.

Propane is used for the inert gas generator required to purge the mild gasification and gasifier circuits during start-up and shutdown. Make-up water is required for the steam system demineralizer and assumed to be available at cost from the mine site.

Solid ash from the gasifier and spent limestone from the flue gas scrubber will be disposed of in the mine, along with other mining wastes. 
Table 5. AMAX 1,000 Ton/Day Operating Cost Summary

\begin{tabular}{|c|c|c|c|c|c|}
\hline & & & Cons & imption & Annual \\
\hline & Cost. $\$$ & Unit & Per Day & $\begin{array}{c}\text { Per Year } \\
(333 \text { Din })^{\mathrm{s}}\end{array}$ & $\begin{array}{c}\text { Cost, } \\
000 ' s \$ / Y r\end{array}$ \\
\hline Feedstocks, Coal & & & & & \\
\hline $\begin{array}{l}\text { To Dryer } \\
\text { To Gasifier } \\
\text { Subtotal }\end{array}$ & $\begin{array}{l}5.00 \\
5.00\end{array}$ & $\begin{array}{l}\text { Per Ton } \\
\text { Per Ton }\end{array}$ & $\begin{array}{r}1,000 \\
265\end{array}$ & $\begin{array}{r}329,000 \\
87,185\end{array}$ & $\begin{array}{r}1,645 \\
\quad 436 \\
2,081\end{array}$ \\
\hline Chemicals & & & & & \\
\hline $\begin{array}{l}\text { Limestone to Gas. } \\
\text { BFW Treating } \\
\text { Subtotal }\end{array}$ & $\begin{array}{r}18.00 \\
0.10\end{array}$ & $\begin{array}{l}\text { Per Ton } \\
\text { Per M Gallons }\end{array}$ & $\begin{array}{r}26 \\
547,200\end{array}$ & $\begin{array}{c}8,488 \\
180,029^{\star b}\end{array}$ & $\begin{array}{r}153 \\
18 \\
171\end{array}$ \\
\hline Utilities & & & & & \\
\hline $\begin{array}{l}\text { Electric Power } \\
\text { Propane } \\
\text { Water } \\
\text { Subtotal }\end{array}$ & $\begin{array}{l}0.055 \\
0.60 \\
0.50\end{array}$ & $\begin{array}{l}\text { Per kWh } \\
\text { Per Gallon } \\
\text { Per M Gallons }\end{array}$ & $\begin{array}{r}240,000 \\
2,655 \\
54,720\end{array}$ & $\begin{array}{c}78,960^{\star c} \\
873,495^{d} \\
18,003^{\star}\end{array}$ & $\begin{array}{l}-- \\
524 \\
\frac{9}{533}\end{array}$ \\
\hline Disposal Costs & & & & & \\
\hline $\begin{array}{l}\text { Ash to Mine } \\
\text { Subtotal }\end{array}$ & 1.50 & Per Ton & 90 & 29,709 & $\frac{45}{45}$ \\
\hline $\begin{array}{l}\text { Labor } \\
\text { Subtotal }\end{array}$ & & & & & $\frac{4,027}{4,027}$ \\
\hline Total & & & & & 6,857 \\
\hline $\begin{array}{l}\text { * Annual figures sho } \\
\text { a } 333 \text { days/year corr } \\
\text { b BFW treating chem } \\
\text { c This electric power } \\
\text { d power product (se } \\
\text { d Propane consumpt }\end{array}$ & $\begin{array}{l}\text { are to b } \\
\text { oonds to } \\
\text { als estima } \\
\text { unished } \\
\text { ext). } \\
\text { corresp }\end{array}$ & $\begin{array}{l}\text { multiplied by } 1 \\
\text { a } 90 \% \text { on-strear } \\
\text { ted by others. }\end{array}$ & $\begin{array}{l}000 \text { to obt } \\
\text { factor. } \\
\text { nerator, is }\end{array}$ & in actual usa & ge. \\
\hline
\end{tabular}




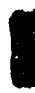

0852

0854

0855

1306

1501

1502

1503

1504

1505

1508

1511

1551

1552

1555

1556

1801

1803

1804

1851

1852

1853

2004

2008

2009

2010

2011

2025

2028

2029

2030

2051

2052

2053

2054

2056

2057

2059

2060

2061

2255

2256

2451

2452

2453

2804

2862

2901

3301

3851
No. No. Inst.

Oper. If Ditf.

$\begin{array}{cc} & 2 \\ 01 / 03 & 5 \\ 01 / 04 & 6 \\ 01 / 02 & 4 \\ 01 / 02 & 4 \\ 01 / 02 & 4 \\ & \\ & 2 \\ & 2\end{array}$

$01 / 04$

$01 / 02$

$01 / 02$

$01 / 02$

$01 / 10$

$01 / 08$

$01 / 10$

$01 / 10$

01/02

$01 / 04$
Description

MEA Acid Gas Removal Package

BFW Treating Package

CTM System Pumps

BFW Pumps

Tempered Water Cooler

Thickener Overtlow PD Pump

Coal Dust Slurry Pump

Pitch Recycle PD Pump

Oil Recycle Pump

Pitch Product PD Pump

Slurry Tank Discharge PD Pump

Water Foed Pump

Scrubber Pump

Activated Carbon Feed Pump

Activated Carbon Concentrate PD Pump

Activated Carbon Tails Pump

Dust Scrubber Exhaust Liquid Ring Compressors

Make Gas Blower

Blower for Combustor

Hydrogen Reactor Gas Compressor

MTM Boost Gas Compressor

Vent Gas Pick-Up Compressor

Hot Screw Conveyors

Cambolt-Type Feod Conveyor

Horizontal Conveyor with Tripper

Rotary Star Valves in Feed Chute to Mild Gas.

Rotary Vahyes under Apex at Dust Cyclones

Screw Feeders to Dryer

Rotary Star Valves Under Feed Bin

Gasifier Feed Coal Screw Conveyor

Gasifier Feed Limestone Screw Conveyor

CTM Reactor Foed Screw Conveyors

CTM Spent Char Cooling Screw Conveyor

Fine Carbon Cooling Screw Conveyor

Medium Carbon Cooling Screw Conveyor

Star Feed Valves

Fine Carbon Screw Conveyor

Medium Carbon Screw Conveyor

Spent Char Scrow Conveyor

Dried Fine Carbon Screw Conveyor

Activated Carbon Shaking Table

Fugitive Dust Collector System

Activated Carbon Circuit Feed Tank Agitator

Act. Carbon Concentrate Storage Tank Agitator

Activated Carbon Tailing Storage Tank Agitator

Inert Gas Generator

Tray Dryer

Dust Collector (Bag Type)

Coal Dust Thickener

Bagging/Pelletizing/Wrapping Plant

Total, Including Lighting \& Misc. at 10\% Use
Oper.

Oper. kW

at Conn

$\begin{array}{rrrr}30.00 & 30 & 19 & 60 \\ 25.00 & 25 & 16 & 25 \\ 20.00 & 60 & 38 & 100 \\ 350.00 & 1,400 & 887 & 2,100 \\ 1,000.00 & 1,000 & 634 & 1,000 \\ 30.00 & 60 & 38 & 120 \\ 1.00 & 1 & 1 & 1 \\ 25.00 & 50 & 32 & 100 \\ 50.00 & 100 & 63 & 200 \\ 0.75 & 1 & 0 & 0\end{array}$

2.00

350.00

350.00

0.50

1.50

0.50

700.00

$1,500.00$

300.00

$2,000.00$

$2,000.00$

50.00

1.50

25.00

18.00

0.50

0.50

1.50

0.50

2

2

2.00

2.00

2.00

2.00

0.50

2.00

2.00

2.00

2.00

2.00

25.00

5.00

3.00

2.50

100

350.00

15.00

2.00

10.00

$$
350
$$

350

1
2

2,800

3,000

600

2,000

2,000

50

3

25

18

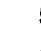

15

5

2

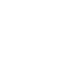

2

2

2

2

2

2
25

3

3
100

350

15
2

10

14,495

9,187

10,108

10,000

14,500
60

25

2,100

1,000

120

100

200

0.75
2

700

700

0.5

1.5

0.5

2,800

3,000

600

2,000

2,000

50

3

25

18

4

15

5

2

2

4

2

2

2

2

2

2

2

2

25

25

25

100

350

15

2
10

16,170

17,790

18,000 
Operating labor requirement breakdowns are given in Table 7. Part of the labor requirements were originally estimated in the Stearns report based on their knowledge of a fluidized-bed mild gasification process and product upgrading facility in a similar part of the country. Additional labor was added for operation of the gasifier and power generation equipment. Labor rates, as well as a benefit factor of 1.38 times the base rate, were supplied by AMAX.

\section{Table 7. Operating Labor Estimate}

\begin{tabular}{|c|c|c|c|c|c|}
\hline \multirow[b]{2}{*}{ Labor Category } & \multicolumn{2}{|c|}{ Labor Rate, $\$ / \mathrm{Hr}$} & \multirow{2}{*}{$\begin{array}{c}\text { Number } \\
\text { People } \\
\text { Required }\end{array}$} & \multirow{2}{*}{$\begin{array}{l}\mathrm{Hrs} / \mathrm{Yr} \mathrm{Ea} \\
\text { (at } 56 \mathrm{Hrs} / \\
\text { Week Ea }\end{array}$} & \multirow{2}{*}{$\begin{array}{l}\text { Annual } \\
\text { Cost, } \\
\$ / Y_{r} \\
\end{array}$} \\
\hline & $\begin{array}{l}\text { Base } \\
\text { (B) }\end{array}$ & $\begin{array}{l}\text { Burdened } \\
\text { (B } \times 1.38 \text { ) }\end{array}$ & & & \\
\hline Supervision & 19.14 & 26.41 & 7 & 2,912 & 538,407 \\
\hline Engineering & 15.95 & 22.01 & 7 & 2,912 & 448,672 \\
\hline Operations & 13.86 & 19.13 & 44 & 2,912 & $2,450,679$ \\
\hline Support Groups & 10.78 & 14.88 & 6 & 2,912 & 259,920 \\
\hline Waste Disposal & 11.72 & 16.17 & 7 & 2,912 & 329,542 \\
\hline Total & & & 71 & & $4,027,220$ \\
\hline
\end{tabular}

\section{PRODUCT REVENUES}

Operating revenues from the sale of products are based on the quantities projected from the process flowsheet and plant material balance. There are seven products generated in the plant which include:

1. Chemically pure, coarse grade carbon used as a substitute for petroleum coke in the manufacture of carbon anodes for aluminum smelting.

2. A fine carbon black material used for filler and reinforcement in rubber products.

3. A high boiling point liquid hydrocarbon pitch product that is used as a binder in carbon anodes for aluminum smelting.

4. A lower boiling point liquid hydrocarbon that is used as a supplemental feedstock in diesel grade fuels.

5. A sodium-based extract derived from the lower boiling point oil that is rich in cresylic acid and used as chemical feedstock. 
6. Activated carbon granules used for organic removal in water pollution control applications.

7. The net excess electricity produced in the plant which is exported on the power grid to other users in the area.

Based on the market analysis conducted in Task 1 of the mild gasification project and on other direct contacts between AMAX and product consumers, estimated selling prices were obtained for the products, taking into account the market supply and demand elasticity, product quantity, and product quality.

The pure carbon product prices are based on published selling prices for equivalent grade carbon black and recent Alumax (the aluminum division of AMAX) purchase prices for anode grade petroleum coke. Total carbon production is assumed to be split evenly between the fine and coarse grades. Pitch prices are based on Alumax purchase prices of anode grade pitch, and the fuel product price is a conservative estimate based on value per million Btu of energy content and considering that the product may require some off-site upgrading before it can be used as a fuel.

The cresylic acid extract (sodium cresylate) contains about $\mathbf{4 0}$ weight percent cresylic acid, expressed as cresylic acid. Talks with Merichem of Houston, who processes cresylic acid into chemical feedstock, established the value of this product, assuming that it will be received as a diluted sodium-based extract.

The activated carbon price is based on the published market price for equivalent grades of activated carbon. This product fits in the low end of the overall activated carbon price structure. kWh.

Excess electricity will be sold at the prevailing local market rate of $\$ 0.055$ per

Table 8 summarizes the product quantities on both a daily and yearly basis, product selling prices, and expected annual product revenue. Values shown in this table assume 100 percent plant on-stream availability. Actual on-stream factors will be applied during the economic evaluation calculations.

\section{ANNUAL CASH FLOW}

Direct comparison of the annual operating and maintenance costs versus the annual revenue to determine simple cash flow is not possible since some of the values assume a 90 percent plant on-stream factor and others assume a 100 percent factor. This was done purposely in preparation to entering the numbers into a spreadsheet to calculate various economic factors. However, if a 90 percent factor is applied to the annual revenues $(0.9 \star 58,948,000)$, the resulting $\$ 53,053,000$ 
revenue can be compared to the $\$ 11,057,000$ value, which gives a simple cash flow value of $\$ 41,996,000$ per year. Use of this value with the $\$ 169$ million capital cost value results in a simple payback of 4.0 years for the project. In a detailed economic evaluation, which is performed later, the simple payback number has little meaning and is only shown here for reference.

\section{Table 8. Annual Plant Product Revenues}

\begin{tabular}{|c|c|c|c|c|}
\hline $\begin{array}{c}\text { Product } \\
\text { Description }\end{array}$ & $\begin{array}{c}\text { Daily } \\
\text { Production, TPD }\end{array}$ & $\begin{array}{c}\text { Annual } \\
\text { Production, TPY }\end{array}$ & $\begin{array}{l}\text { Price, } \\
\$ / T \\
\end{array}$ & $\begin{array}{l}\text { Revenue, } \\
\text { \$YYear }\end{array}$ \\
\hline Fine Carbon & 110 & 40,100 & 500 & $20,050,000$ \\
\hline Coarse Carbon & 110 & 40,100 & 250 & $10,025,000$ \\
\hline Pitch & 47 & 17,200 & 250 & $4,300,000$ \\
\hline Fuel Liquid & 16 & 5,800 & 125 & 725,000 \\
\hline Chemical Feed & 10 & 3,700 & 500 & $1,850,000$ \\
\hline Activated Carbon & 30 & 10,950 & 1,000 & $10,950,000$ \\
\hline Electricity, MWh & 528 & 192,700 & $0.055 / \mathrm{kWh}$ & $10,598,000$ \\
\hline
\end{tabular}

Total Revenue

$58,498,000$ 


\section{ECONOMIC EVALUATION}

This chapter analyzes the capital cost, operating cost, and sales revenue estimates to evaluate economic viability of the 1,000 ton/day mild gasification and product upgrading commercial demonstration plant. The evaluation consists of a discounted cash flow rate of return (DCFROR) analysis of the project cost elements, followed by sensitivity analysis of the cost elements to determine their leverage potential on the project. Using the DCFROR analysis and assuming zero (\$0.00) net present value (NPV) at the project initiation point, the base case analysis for a $\$ 169$ million capital investment results in a DCFROR of 16.4 percent.

\section{DCFROR CALCULATIONS}

A Lotus 123 spreadsheet model developed by Amax Coal Company was used to perform the DCFROR calculations. The model was written to cover a number of potential applications and has more features than was required in this project. For example, the model addresses depletion allowances and credits applicable to mining projects, which are not required in our study. As a result, there are many blank areas in our spreadsheet analysis that should simply be ignored.

\section{Procedures}

Input to the spreadsheet consists of the total plant capital cost estimate developed in the previous section of $\$ 169$ million, the base case operating and maintenance costs shown in Table 4, and the annual sales revenues presented in Table 8. The base case DCFROR is shown in Table 9, which is the spreadsheet printout and is multi-page. The table consists of several sections consisting of:

1. Revenue detail showing operating rate (on-stream factor), product tonnages on a 100 percent basis, product selling price, inflation index, and sales revenues.

2. Cost detail showing raw material usage, unit cost, and annual cost. Also shown is a breakdown on the yearly labor cost, chemicals and supplies, utilities, maintenance, and disposal costs. Some of this data has already been adjusted for a 90 percent on-stream factor, while the other is on a 100 percent basis.

3. A data section showing sales and expenses and, in particular, capital expenditures listed under the fixed investment heading in project years 1-4.

4. Ar: income statement section that contains no input requirements as far as this particular analysis is concerned but provides some of the data for tax calculations. 


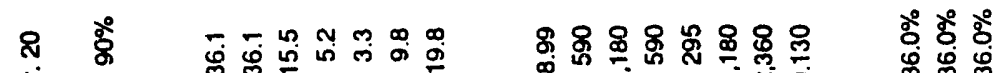

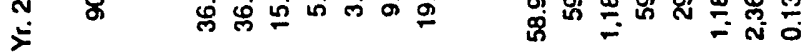

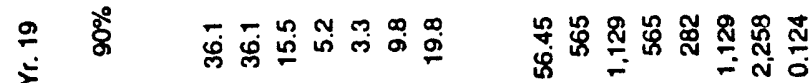

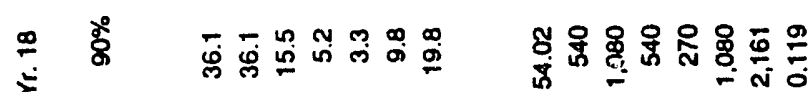

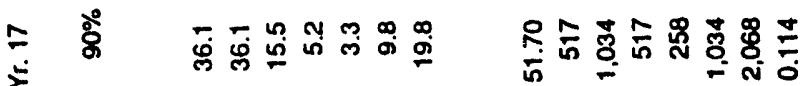

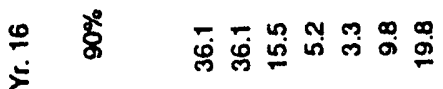

$\stackrel{8}{8}$

总

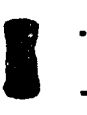

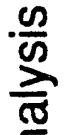

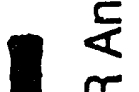

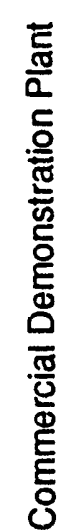

竞

.

竞

응

递

$\ddot{\circ}$

$\stackrel{\circ}{2}$

음

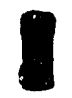

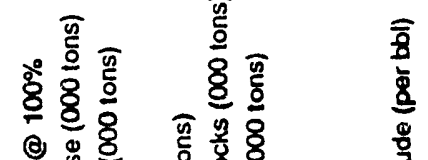

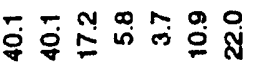

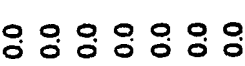

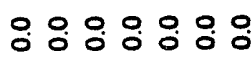

영영영용영

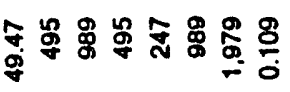

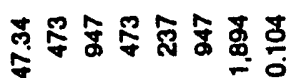

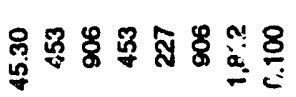

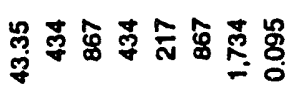

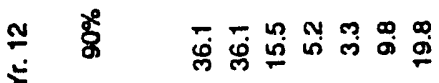

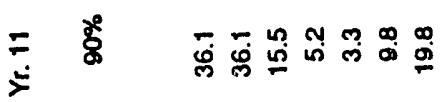

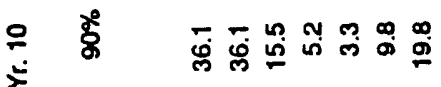

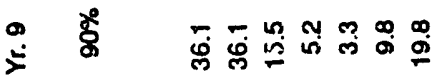

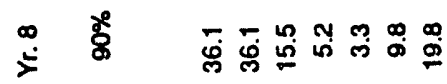

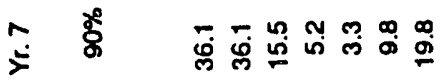

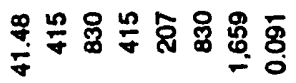

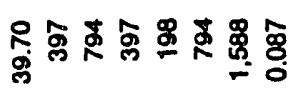

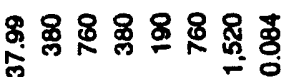

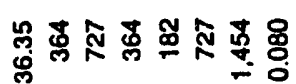

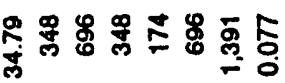

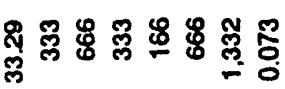

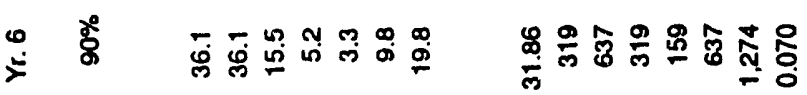

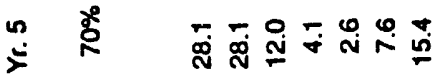

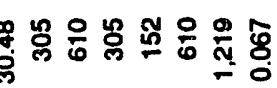

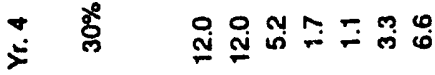

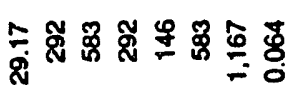

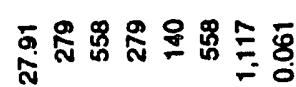

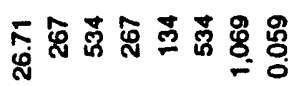

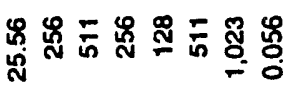

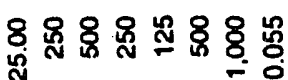

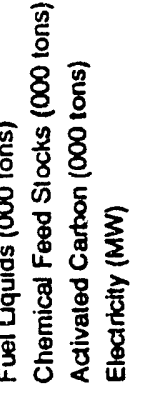

品

ฒำำ

ฟู

$\therefore$

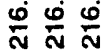

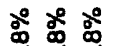

石哭

ถ้ำ

玉ㅎำ

ํำ

$\Phi$

赵然串

$\underline{\mathbf{\Phi}} \mathbf{\Phi} \overline{\mathbf{\Phi}}$

ำㅇำ

요욜

ㅇํㅇㅇํㅇ

응.

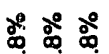

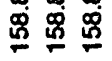

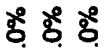

通兽

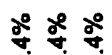

온

ํำํำ

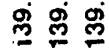

ม้ำ

宷㗭总

ㅇํำ

กิำ

里然

$\bar{N} \bar{N}$

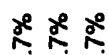

$\stackrel{\underline{0}}{\underline{\underline{9}} \underline{\underline{\varphi}}}$

ํำ

EE

电央

g.

象

ปั 웡 웜

$58 \%$

8 安 8
믈

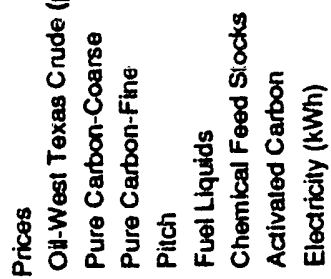

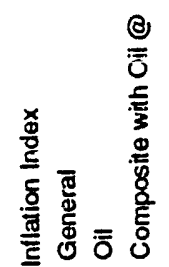

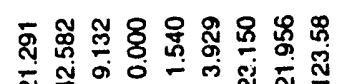

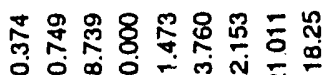

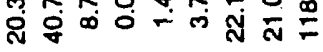

可善 800

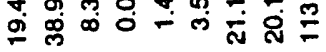

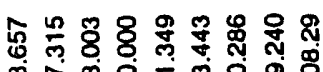

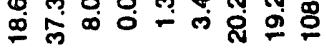

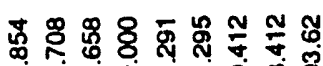

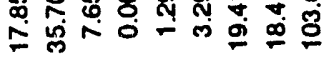

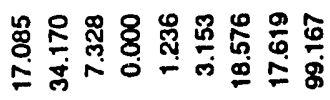

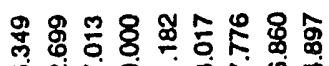

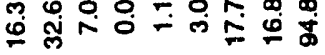

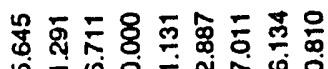

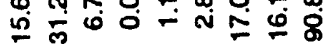

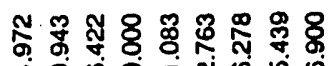

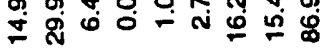

ำ

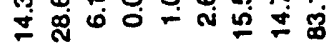

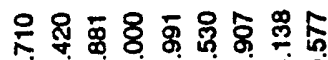

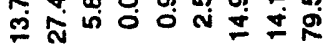

요요

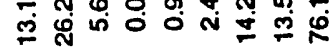

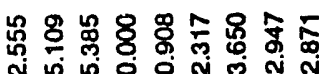
ำ

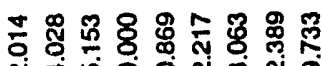

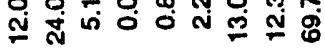

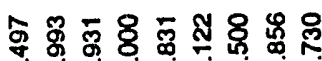
$=$ สํำ

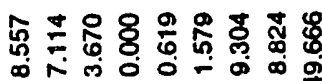

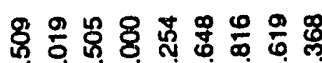

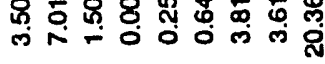

형항형영영영영영

8영형형영

88888080

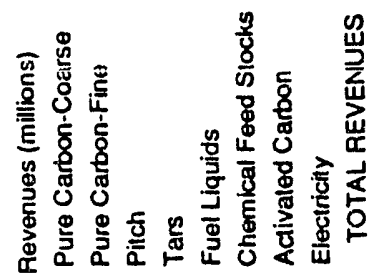




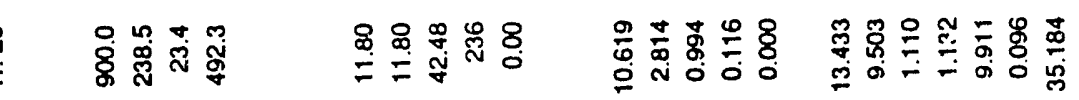

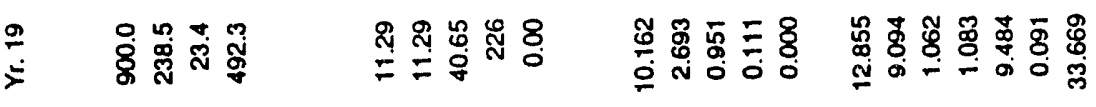

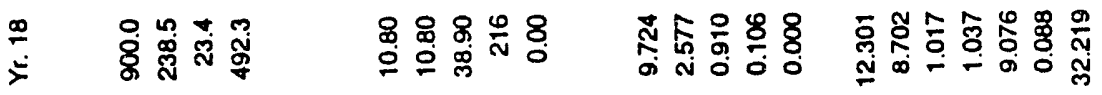

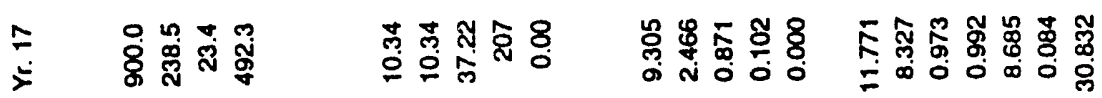

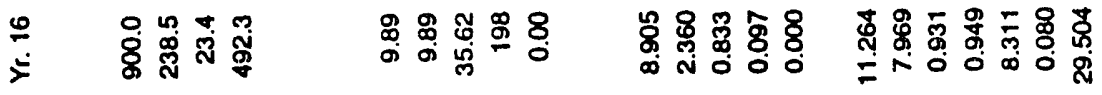

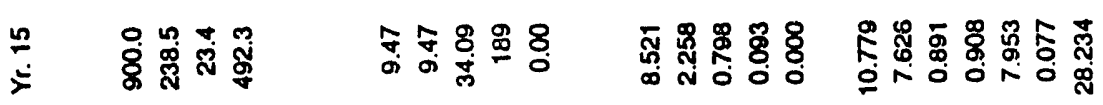

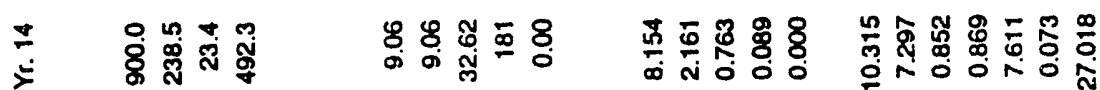

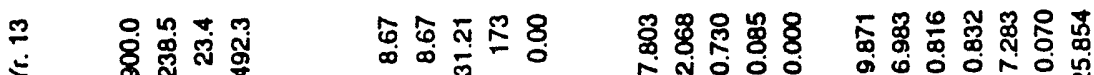

$>$ तNOOO

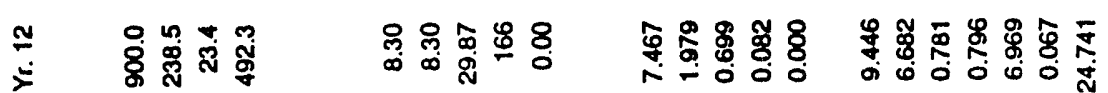

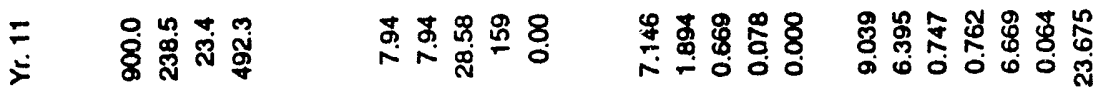

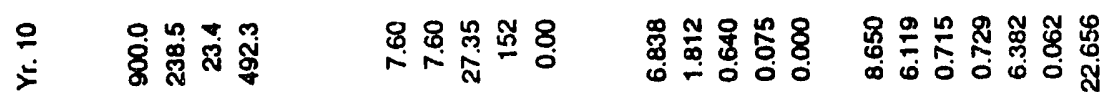

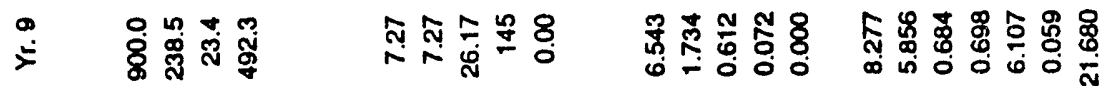

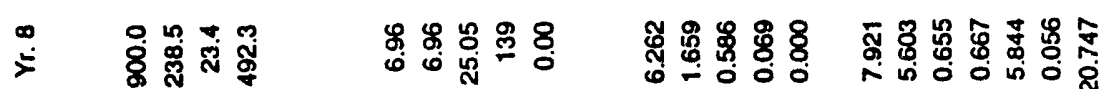

-

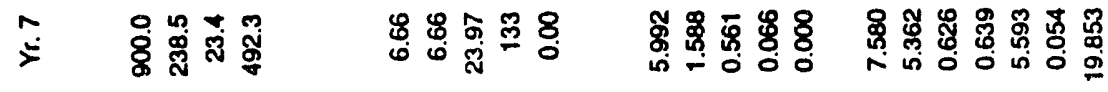

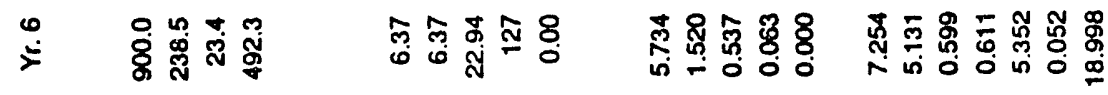

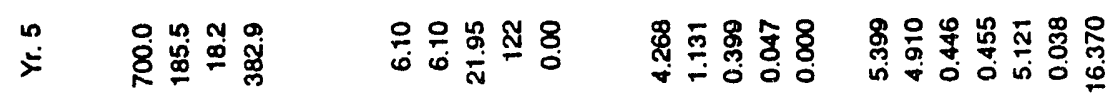

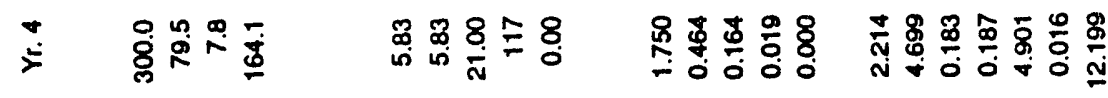

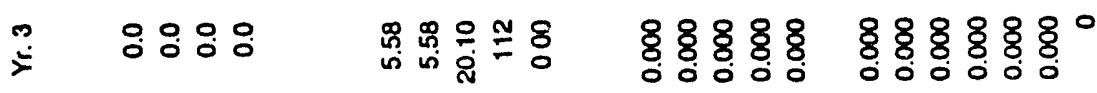

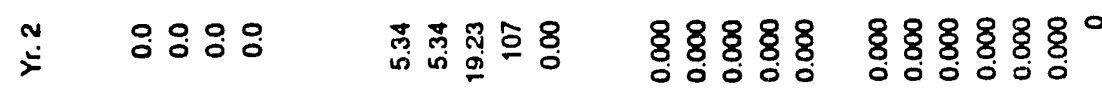

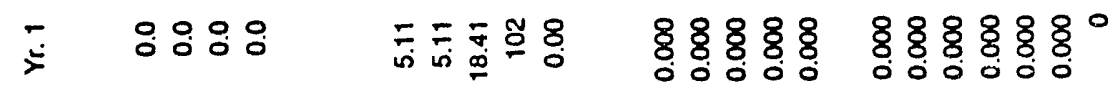

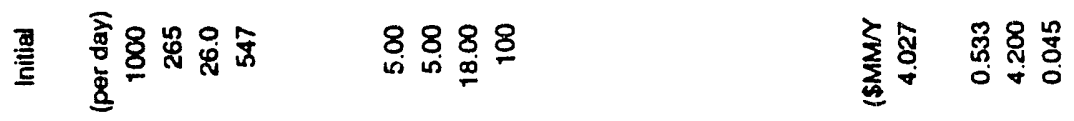

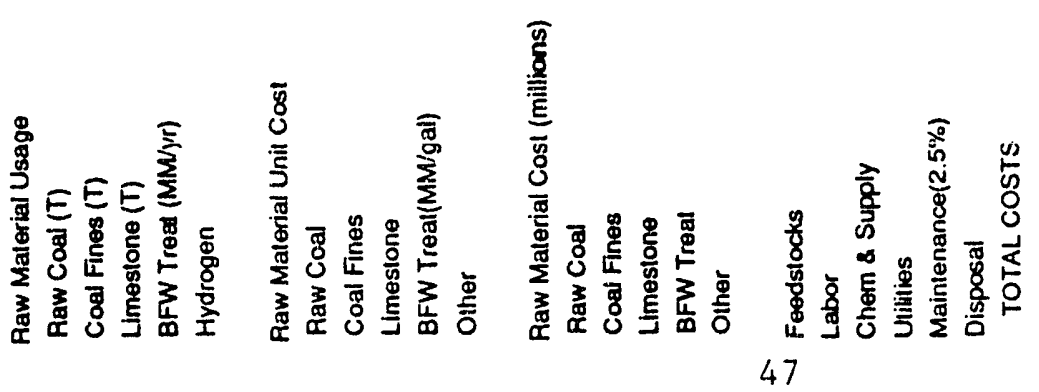




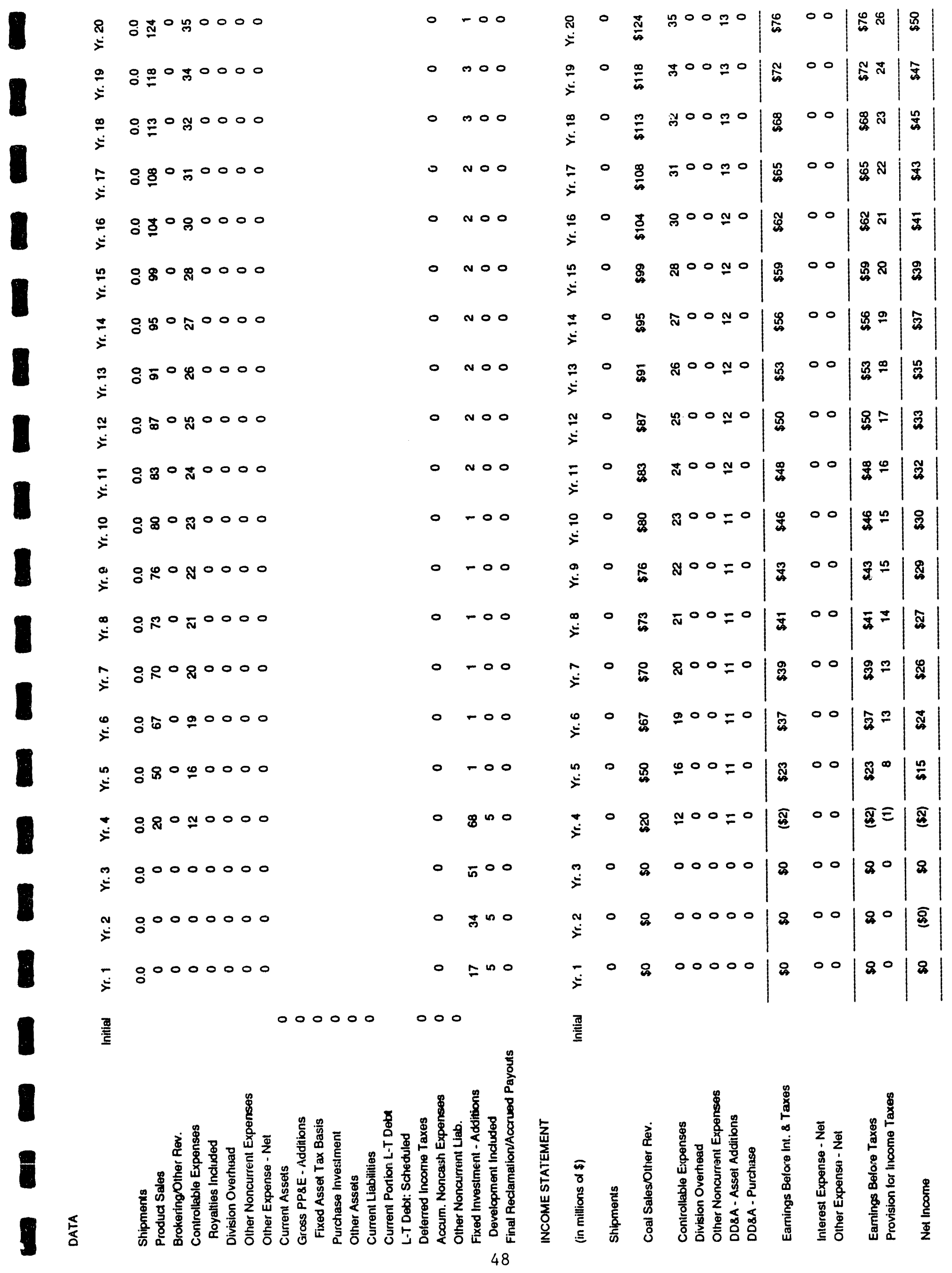




\begin{tabular}{|c|c|c|c|c|c|c|c|c|c|c|}
\hline 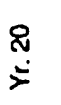 & $\stackrel{\sim}{N}$ & $\mathscr{L}^{\circ} \&^{\circ}$ & 玉0 & $\bar{\aleph}$ & $\underline{n}^{\circ}$ & $\frac{n}{45}$ & 0 N 00 & $\hat{\pi}$ & + & $\bar{\pi}$ \\
\hline$\stackrel{9}{=}$ & N & $\stackrel{\omega^{\circ}}{\circ} \underline{\Phi}^{\circ}$ & $\infty 0$ & $\ddot{i n}$ & $\underbrace{\circ}$ & $\frac{\pi}{\Delta}$ & 0 is 00 & \& & $\simeq$ & $\overline{3}$ \\
\hline$\stackrel{\stackrel{\infty}{亡}}{\stackrel{5}{亡}}$ & $\mathfrak{N}$ & 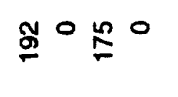 & $=0$ & 암 & $\frac{ \pm}{\Delta}$ & $\frac{\pi}{4}$ & 0000 & $\mathbb{W}$ & $\stackrel{\infty}{-}$ & 웅 \\
\hline 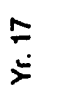 & มี & $\Phi^{\circ} \overbrace{}^{\circ} \circ$ & $\hat{N}^{0}$ & $\frac{9}{8}$ & $\underbrace{\circ}$ & $\frac{m}{\infty}$ & $0=00$ & $\dddot{\pi}$ & 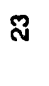 & \& \\
\hline$\stackrel{\mathscr{\prime}}{\check{\Sigma}}$ & $\bar{N}$ & $\underline{\Phi}^{\circ} \stackrel{g}{0}^{\circ}$ & $\stackrel{\infty}{0}$ & 嵒 & $\simeq_{0}^{\circ}$ & $\frac{\pi}{50}$ & $0 \cong 00$ & జ & 요 & 品 \\
\hline$\frac{n}{5}$ & \& & $\underline{\Phi}^{\circ} \circ \hat{\Phi}^{\circ}$ & 90 & $:$ & $^{\circ} 0$ & $\frac{N}{4}$ & 0 \& 00 & 没 & 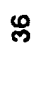 & 8 \\
\hline$\stackrel{ \pm}{亡}$ & 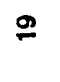 & $\Phi^{\circ} \stackrel{\sim}{\underline{N}} \circ$ & 80 & E & $\Sigma^{0}$ & $\equiv$ & $0 \mathbb{N} 00$ & 虽 & 9 & E \\
\hline$\stackrel{2}{=}$ & 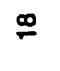 & $\underline{\Phi}^{\circ} \cong 0$ & 80 & $\widehat{\mathscr{\Phi}}$ & $\Sigma^{-0}$ & $\bar{\pi}$ & 0 ล 00 & $\underset{\mathbb{S}}{\infty}$ & 9 & $\widehat{\mathscr{Q}}$ \\
\hline$\stackrel{\cong}{\check{\Sigma}}$ & $=$ & $\stackrel{90}{\circ}^{\circ} 8^{\circ}$ & 90 & $\oiint$ & $0_{0}^{\circ}$ & 웃 & 0800 & $\bar{z}$ & 足 & $\mathscr{S}$ \\
\hline$\stackrel{5}{亡}$ & $=$ & $\underline{5}^{\circ}$ ஃ & $\otimes^{\circ}$ & $\frac{8}{6}$ & $0^{\circ}$ & $\frac{0}{4}$ & ० से०० & \pm & $\overline{6}$ & 은 \\
\hline $\begin{array}{l}\stackrel{0}{亡} \\
亡\end{array}$ & $\dddot{\varphi}$ & $\stackrel{N^{\circ}}{ }$ & $\stackrel{\circ}{\circ}$ & $\frac{5}{E}$ & $^{\circ}$ & 운 & 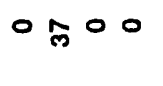 & $\stackrel{0}{4}$ & $\mathbb{8}$ & $\frac{ \pm}{\Delta}$ \\
\hline$\dot{0}$ & 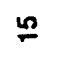 & \pm 080 & $\stackrel{\infty}{0}^{\circ}$ & 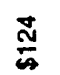 & $\Leftrightarrow 0$ & $\mathscr{8}$ & 0 हे 00 & 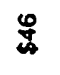 & F & $\underset{\underline{a}}{\mathbb{2}}$ \\
\hline$\stackrel{\infty}{\Sigma}$ & 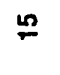 & 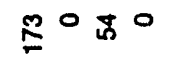 & $\stackrel{0}{=}$ & $\frac{m}{n}$ & 20 & 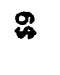 & 0 命 00 & $\stackrel{0}{1}$ & $\Phi$ & $\frac{0}{m}$ \\
\hline$\stackrel{5}{亡}$ & \pm & $\cong 090$ & $\mathbb{2}^{\circ}$ & $\frac{8}{4}$ & $\mathscr{0}$ & $\mathbb{a}$ & ○ n్లం 0 & \pm & 8 & $\frac{2}{-2}$ \\
\hline$\stackrel{0}{\Sigma}$ & $m$ & $\Sigma^{\circ}$ న్లం & $g^{\circ}$ & ָั & $\$ 0$ & $\mathbb{B}$ & 0 \& 00 & $\bar{x}$ & $\Xi$ & $\frac{\tilde{m}}{\omega *}$ \\
\hline$\stackrel{\infty}{=}$ & 우 & $g^{0} \bar{N}^{\circ}$ & $9^{\circ}$ & $\frac{8}{5}$ & $\leftrightarrow 0$ & $\mathscr{H}$ & $\circ R_{0} \circ 0$ & 蛋 & 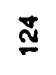 & $\frac{9}{4}$ \\
\hline$\stackrel{+}{*}$ & + & $\stackrel{\circ}{\circ} 0=0$ & $\underline{p}^{\circ}$ & 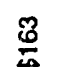 & $\approx 0$ & $\approx$ & ○ ม & $\Xi$ & $\stackrel{\infty}{m}$ & $\frac{8}{6}$ \\
\hline$\stackrel{\infty}{\check{\infty}}$ & 0 & 5000 & $\underline{0}^{0}$ & 흠 & $8^{\circ}$ & 8 & $0 \geq 00$ & $\frac{5}{4}$ & 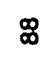 & $\frac{\overline{0}}{4}$ \\
\hline$\stackrel{\sim}{\check{\Sigma}}$ & 0 & 5000 & $\bar{n}^{\circ}$ & $\bar{n}$ & $0^{\circ}$ & $\&$ & $0 \sim 00$ & $\hat{n}$ & 8 & $\overline{5}$ \\
\hline $\bar{\Sigma}$ & 0 & $=000$ & $=0$ & $\Sigma$ & 80 & $\&$ & 0000 & 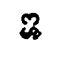 & \pm & 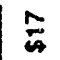 \\
\hline 震 & 0 & 0000 & 00 & 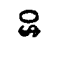 & $\mathscr{g}^{\circ}$ & \& & 0000 & \& & 0 & 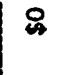 \\
\hline
\end{tabular}

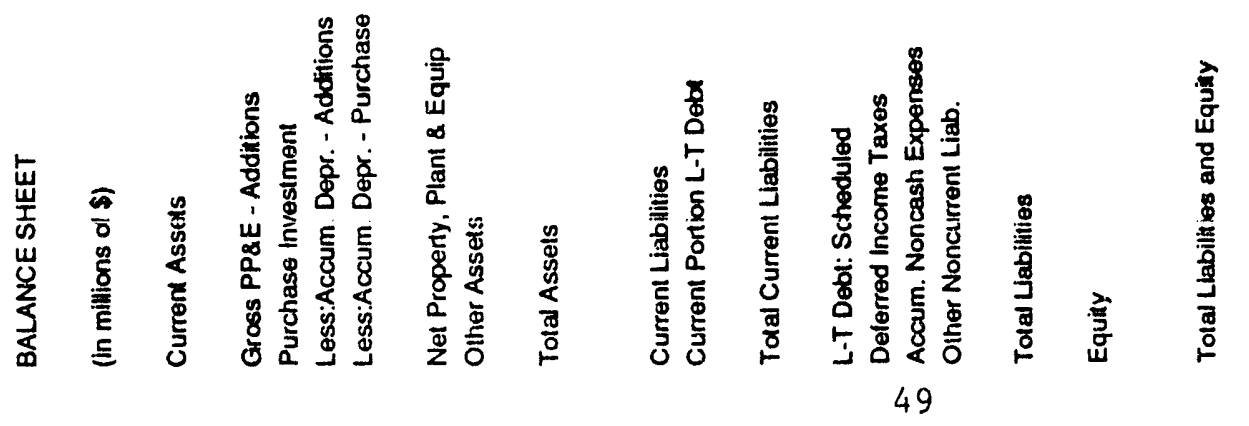




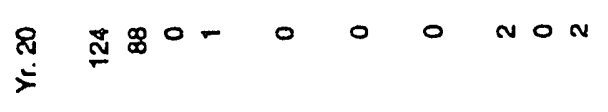

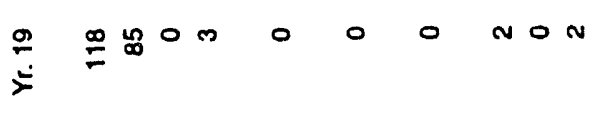

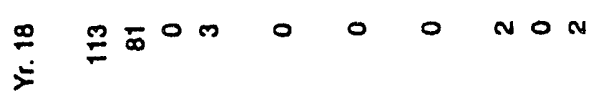

$$
\begin{aligned}
& \text { = BRon o o o nOn }
\end{aligned}
$$

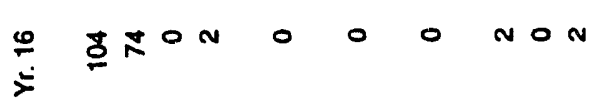

$$
\begin{aligned}
& \frac{1}{2} B \pi_{0 N} \\
& \pm 280 n+N O N \\
& \text { D }
\end{aligned}
$$

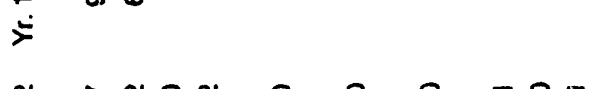

$$
\begin{aligned}
& \text { స } \\
& =800 N \quad 000+0 \\
& \text { 융 } 0 \text { in } 0000
\end{aligned}
$$

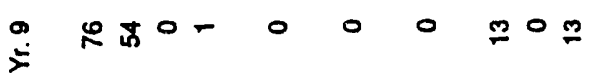

$$
\begin{aligned}
& \text { 方 } \\
& \text { 广 }
\end{aligned}
$$

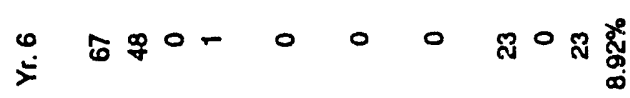

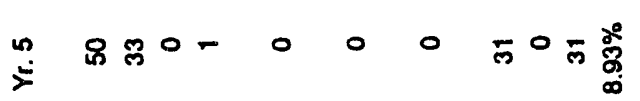

$$
\begin{aligned}
& \text { 芒 }
\end{aligned}
$$

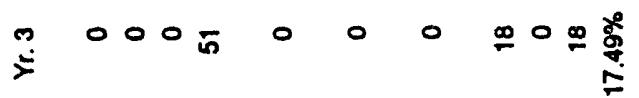

$$
\begin{aligned}
& \text { ก }
\end{aligned}
$$

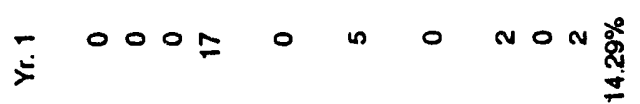

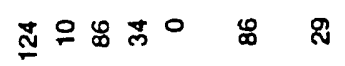

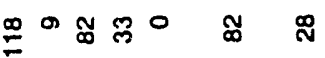
무ㅇㅛㅠㅇㅠ 웅유유 웅 ำกำก ก

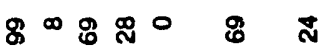
요용 -ก

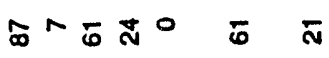

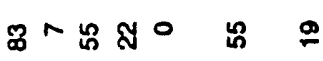
வீำㅇ ำกㄴา ํํำก응 ํำ ํㅠㅇ ₹ ธกตกำ

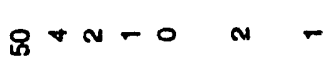

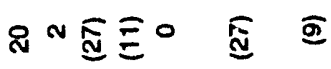

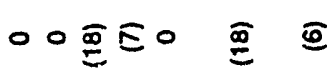

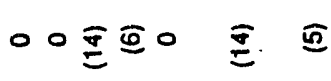

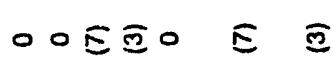

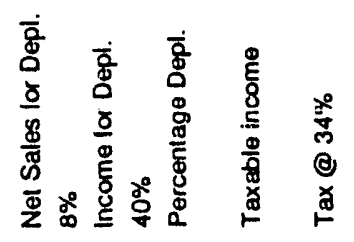




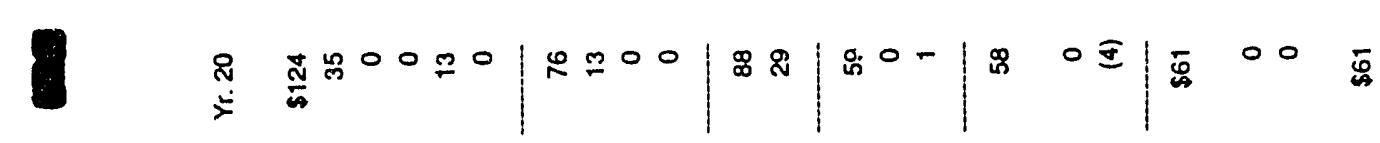

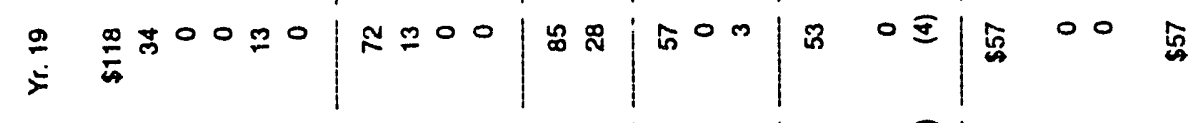

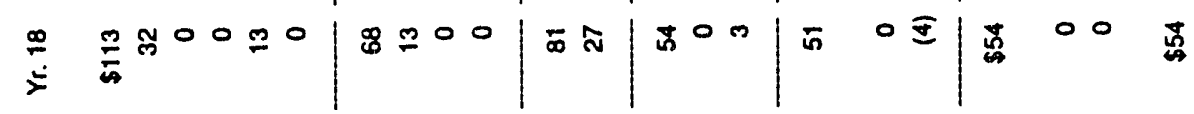

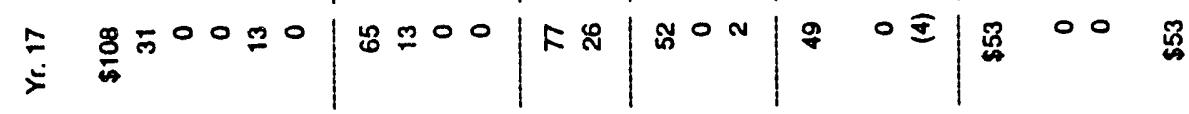

竞

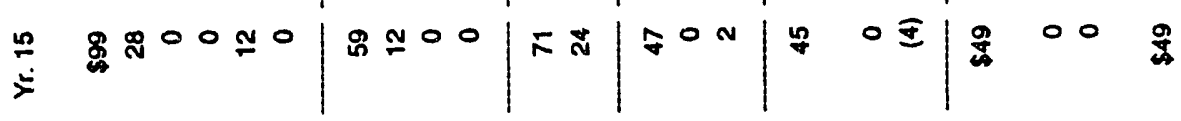

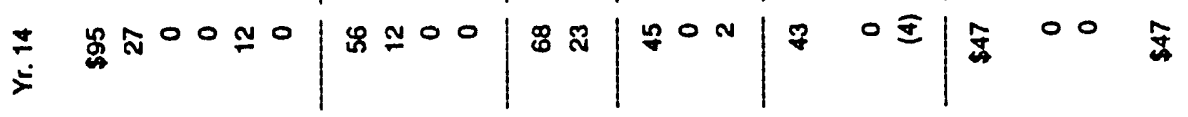

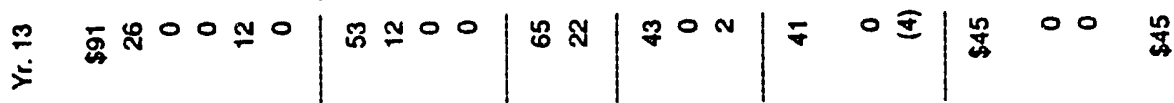

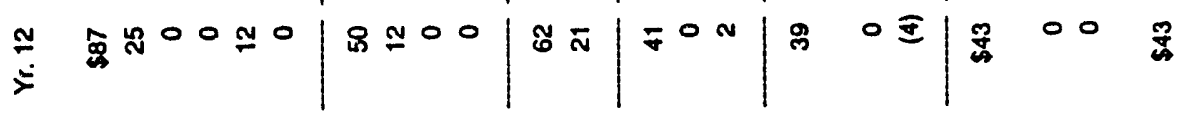

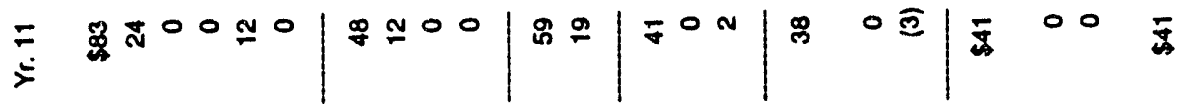

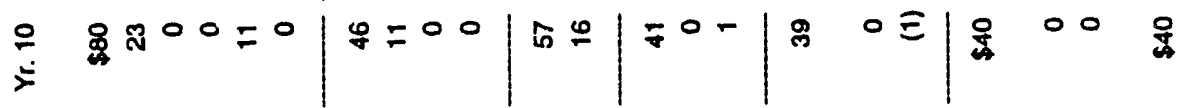

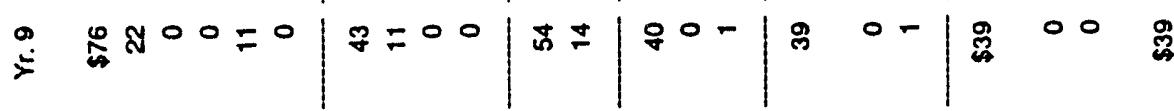

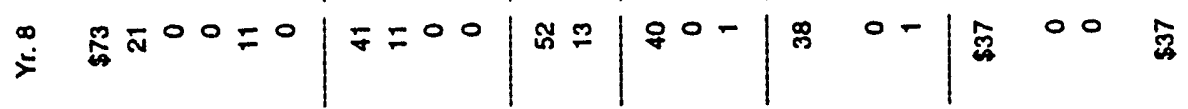

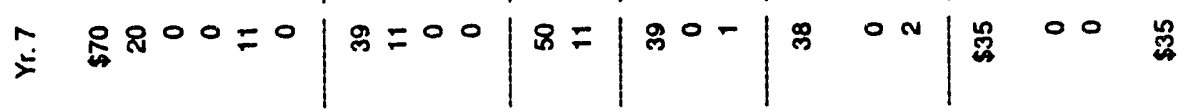

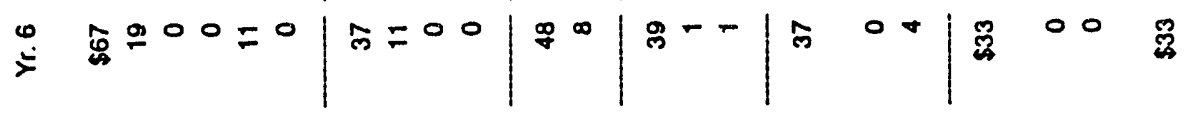

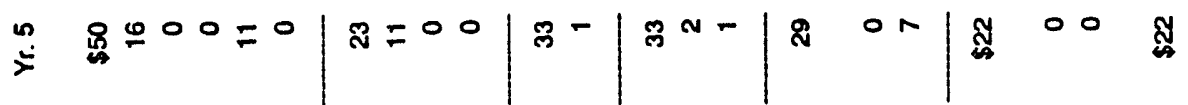

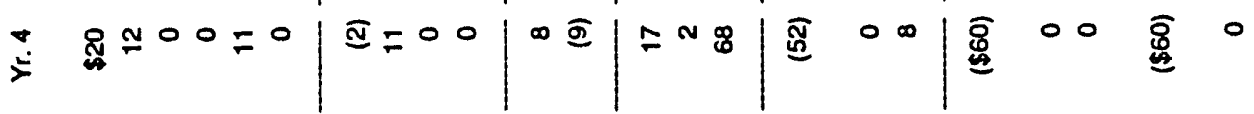

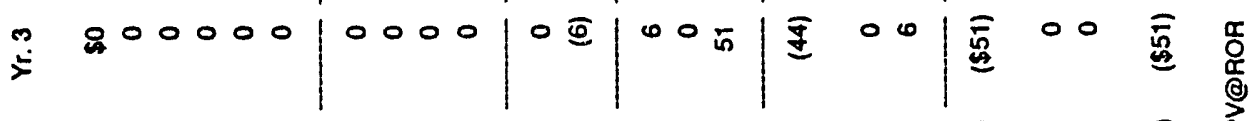

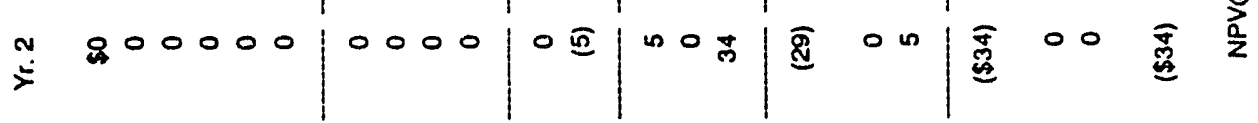

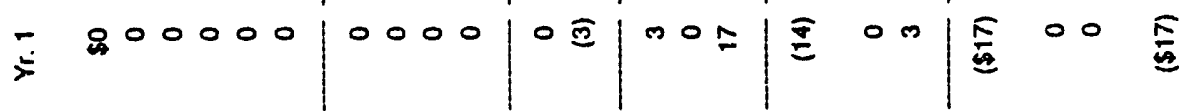

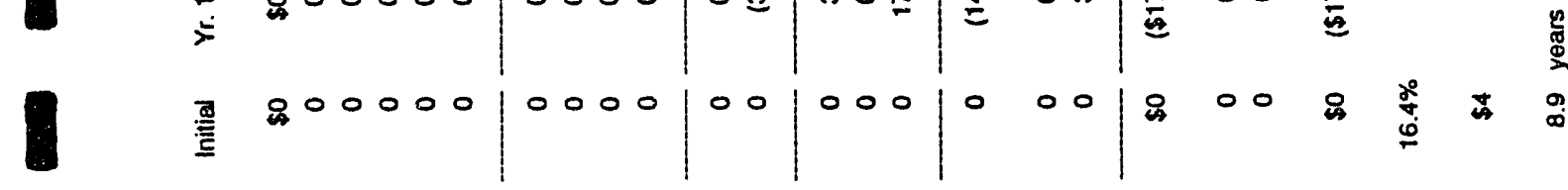

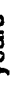

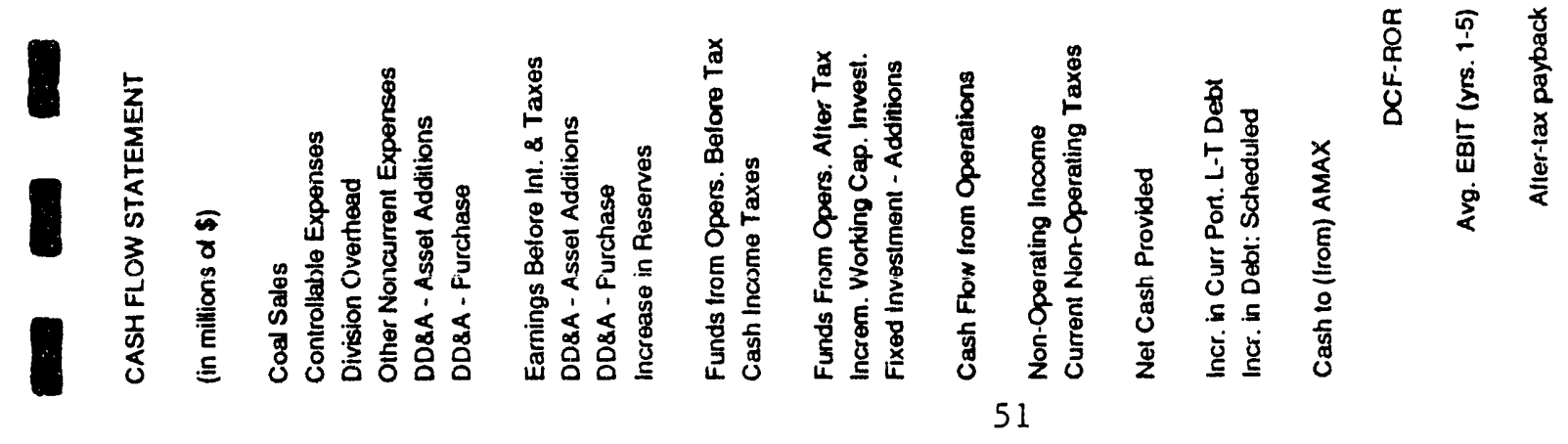


5. A balance sheet section that also did not require any input information for this application.

6. Tax computation data, depreciation data, tax calculations, and the federal tax rate of 34 percent.

7. The final cash flow statement pulls information from the other sections together and calculates the DCFROR. There are two ways to do the DCFROR calculation. One is to specify a DCFROR value and then evaluate the NPV of the project at the stated ROR value. The second, which is the method used in this evaluation, is a trial and error calculation where the DCFROR is continuously adjusted to achieve a NPV of zero.

\section{Assumptions}

A number of assumptions were used in performing the DCFROR analysis:

1. The total project life was 20 years, with construction occurring in years $1,2,3$, and part of the 4th year. During the 4th year, on-stream plant availability was 30 percent and then increased to 90 percent for the rest of the project life.

2. The inflation index was 2.3 percent in the second year and then accelerated to 4.5 percent for the remainder of the project life. The model has the capability to use different indices for operating costs and revenues, but for our case, we assumed that both were equal.

3. The capital cost investment was spread out over the first 4 years of the project, with 10 percent of the total amount being spent in year 1, 20 percent in year 2, 30 percent in year 3, and the final 40 percent in year 4 .

4. In addition to the initial capital investment, the project was burdened with two other costs. In the first 4 years of the project, $\$ 5$ million per year was capitalized for development and supervision expenses, and in each year after production started, some expense was considered for capital improvement projects. This amount started at $\$ 1$ million per year and escalated to $\$ 3$ million in the later years.

5. Initial provision of working capital, and recovery of working capital, plus salvage value recovery, were not considered in this analysis.

6. The initial capital investment was depreciated over the first 10 years of the project, using a straight line depreciation method.

7. The federal income tax rate was set at 34 percent. 


\section{Base Case Data}

In the revenue detail section of the spreadsheet, the following annual production volumes (in 1,000's of tons) and selling prices (in \$) were entered. (Electricity was entered in MW capacity and kWh units for price.)

\section{Annual Volume Unit Price}

Pure Carbon, Coarse

Pure Carbon, Fine

Pitch

Fuel Liquid

Chemical Feedstock

Activated Carbon

Electricity
40.1

40.1

17.2

5.8

3.7

10.9

$22 \mathrm{MW}$
250

500

250

125

500

1,000

$0.055 / \mathrm{kWh}$

In the cost detail section of the spreadsheet, information was entered for raw materials (coal) and chemical and supplies (limestone and BFW treat chemicals) for both daily usage amounts and price per ton. Other yearly cost data was entered for labor, utilities, maintenance, and disposal as shown below.

\begin{tabular}{lccc} 
& $\begin{array}{c}\text { Daily } \\
\text { Volume }\end{array}$ & $\begin{array}{c}\text { Unit } \\
\text { Price }\end{array}$ & $\begin{array}{c}\text { Annual } \\
\text { Cost }\end{array}$ \\
\cline { 2 - 4 } & & & \\
Feed Coal (Tons) & 1,000 & 5 & \\
Coal Fines & 265 & 5 & \\
Limestone & 26.0 & 18 & \\
BFW Treat (MM/y Usage) & 547 & 100 (MMgal) & \\
Labor (MM\$/yr) & & & 4.027 \\
Utilities & & & 0.533 \\
Maintenance & & & 4.200 \\
Disposal Cost & & & 0.045
\end{tabular}

In the data section of the spreadsheet, the $\$ 169$ million capital investment was entered as 17 in year 1, 34 in year 2, 51 in year 3, and 68 in year 4 (all values in millions).

The results of this spreadsheet calculation show that the DCFROR for the base case is 16.4 percent at a NPV of zero. Simple payback after taxes was 8.9 years. 


\section{SENSITIVITY ANALYSIS}

Although the base case analysis shows that the project has excellent economic potential, sensitivity analysis was performed to determine if the economics were particularly sensitive to capital cost expenditure, operating and maintenance costs, and/or sales revenues. All of these cost elements were changed in 20 percent increments, from 60 percent of the base case data to 140 percent, to determine their sensitivity and impact on the DCFROR value.

\section{Capital Costs}

Input of sensitivity data for capital cost expenditure was a straightforward calculation. The values listed below in Table 10 were used as input which resulted in the DCFROR values and simple payback values after taxes.

\begin{tabular}{|c|c|c|c|}
\hline $\begin{array}{l}\text { Sensitivity } \\
\text { Factor, \% }\end{array}$ & $\begin{array}{l}\text { Capital Cost, } \\
\text { Million } \$ \\
\end{array}$ & $\begin{array}{l}\text { DCFROR } \\
\text { at } 0 \mathrm{NPV} \\
\end{array}$ & $\begin{array}{l}\text { Simple } \\
\text { Payback }\end{array}$ \\
\hline 60 & 101.4 & 23.3 & 7.0 \\
\hline 80 & 135.2 & 19.3 & 8.1 \\
\hline 100 & $169^{a}$ & 16.4 & 8.9 \\
\hline 120 & 202.8 & 14.3 & 9.6 \\
\hline 140 & 236.6 & 12.5 & 10.3 \\
\hline
\end{tabular}

a Base case.

Figure 3 shows the DCFROR plotted against capital expenditure. Basically, the data show that at the higher capital expenditure values, the change in the DCFROR becomes smaller for each 20 percent change. Using the values at 100 and 120 percent for reference, the change is 1.9 percent (absolute).

\section{Operating Costs}

Adjusting the operating cost data for sensitivity analysis was done in the same manner as adjusting the capital costs, as shown in Table 11. The technique was a little more involved since there was not just one number that could be factored. Instead, either the unit costs or annual costs shown earlier in the base case input data listing were factored individually. The magnitude of the operating cost value in the initial year of the project is somewhat meaningless, since the number changes each year due to inflation and on-stream availability, but in year 6 
of the project, which is the first year at full capacity, the number is $\$ 18.988$ million. When adjusted for inflation, it is $\$ 14.904$ million, or about $\$ 3$ million per 20 percent change. Reference operating costs in present day costs are shown in the table to give some indication of the magnitude of the changes.

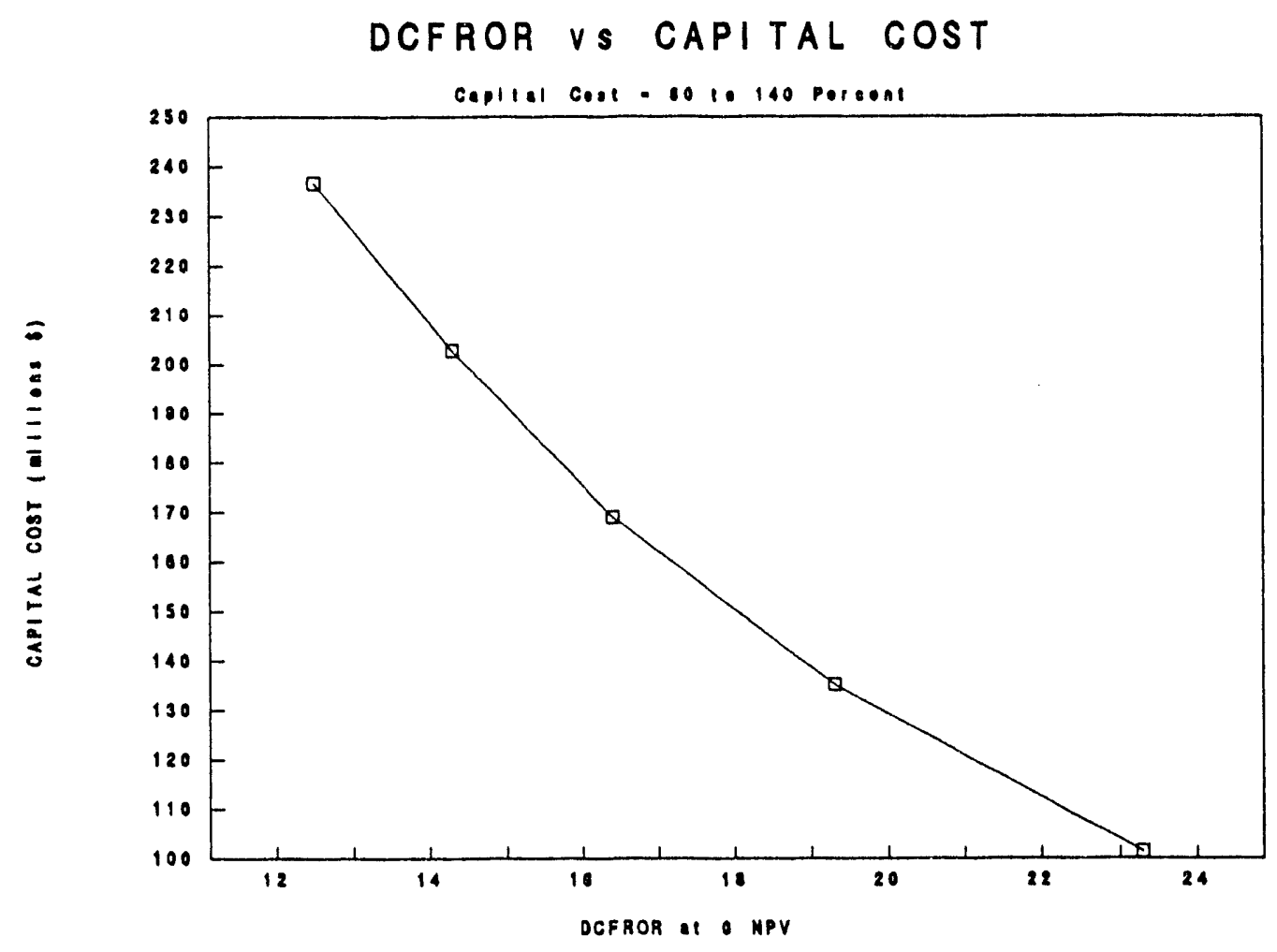

Figure 3. DCFROR sensitivity versus capital cost.

Table 11. DCFROR Sensitivity Versus Operating Costs

\begin{tabular}{ccccc}
$\begin{array}{c}\text { Sensitivity } \\
\text { Factor, \% }\end{array}$ & $\begin{array}{c}\text { Reference Cost, } \\
\text { Million \$ }\end{array}$ & $\begin{array}{c}\text { DCFROR } \\
\text { at O NPV }\end{array}$ & $\begin{array}{c}\text { Simple } \\
\text { Payback }\end{array}$ \\
\cline { 1 - 2 } 60 & 6.0 & & 18.6 & 8.2 \\
80 & 8.0 & & 17.6 & 8.5 \\
100 & $10.0^{\mathrm{a}}$ & & 16.4 & 8.9 \\
120 & 12.0 & & 15.3 & 9.3 \\
140 & 14.0 & 14.0 & 9.7
\end{tabular}

- Base case. 
Figure 4 shows the DCFROR plotted against changes in operating cost percentage changes. Compared to capital cost sensitivity, a 20 percent change in operating costs results in a smaller change in DCFROR, but looking at the dollars, a 20 percent change in capital is $\$ 34$ million, while a 20 percent change in operating cost is $\$ 2$ million (reference cost basis). Dollar for dollar, changes in operating cost have a larger effect on the DCFROR.

\section{Sales Revenue}

The sensitivity calculation for sales revenues were made by factoring the unit costs shown earlier in the discussion of sales revenue in the base case discussion. Taking the sales revenues data for year 5 of the project and then adjusting back to present day values indicates that the base case value will be about $\$ 40$ million, therefore a 20 percent change is about $\$ 8$ million. The data are shown below in Table 12.

\begin{tabular}{|c|c|c|c|}
\hline $\begin{array}{l}\text { Sensitivity } \\
\text { Factor, \% }\end{array}$ & $\begin{array}{l}\text { Reference Cost, } \\
\text { Million \$ }\end{array}$ & $\begin{array}{l}\text { DCFROR } \\
\text { at } 0 \mathrm{NPV}\end{array}$ & $\begin{array}{c}\text { Simple } \\
\text { Payback }\end{array}$ \\
\hline 60 & 24.0 & 7.0 & 13.4 \\
\hline 80 & 32.0 & 12.4 & 10.4 \\
\hline 100 & $40.0^{\mathrm{a}}$ & 16.4 & 8.9 \\
\hline 120 & 48.0 & 19.8 & 8.0 \\
\hline 140 & 56.0 & 22.8 & 7.3 \\
\hline
\end{tabular}

a Base case.

Figure 5 shows the relationship between DCFROR sensitivity and sales revenue. A 20 percent change in revenue above the base case amounts to about $\$ 8$ million and causes a 3.4 percent change in DCFROR. When compared to operating costs where a 20 percent change amounted to $\$ 2$ million, the change in DCFROR was 1.2 percent. This means that equivalent dollar changes in operating costs have more effect on project profitability than equivalent dollar changes in sales revenue. This basically relates back to the tax rules where you are taxed more for making money than you are credited for loosing money.

\section{Combined Effects}

Figure 6 shows the relationship between DCFROR versus both revenue and capital plotted on the same graph. The operating revenue sensitivities are plotted 


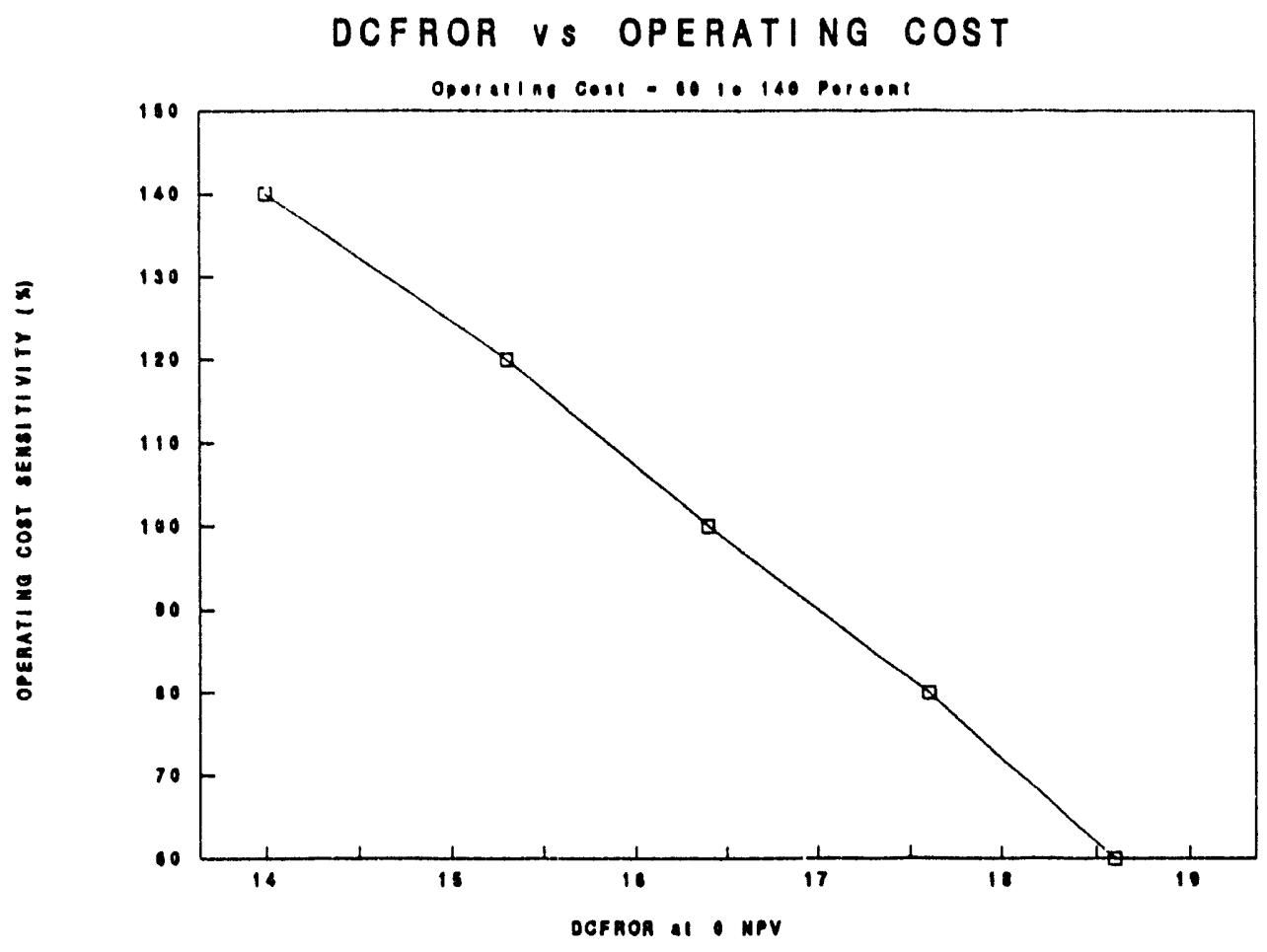

Figure 4. DCFROR sensitivity versus operating costs.

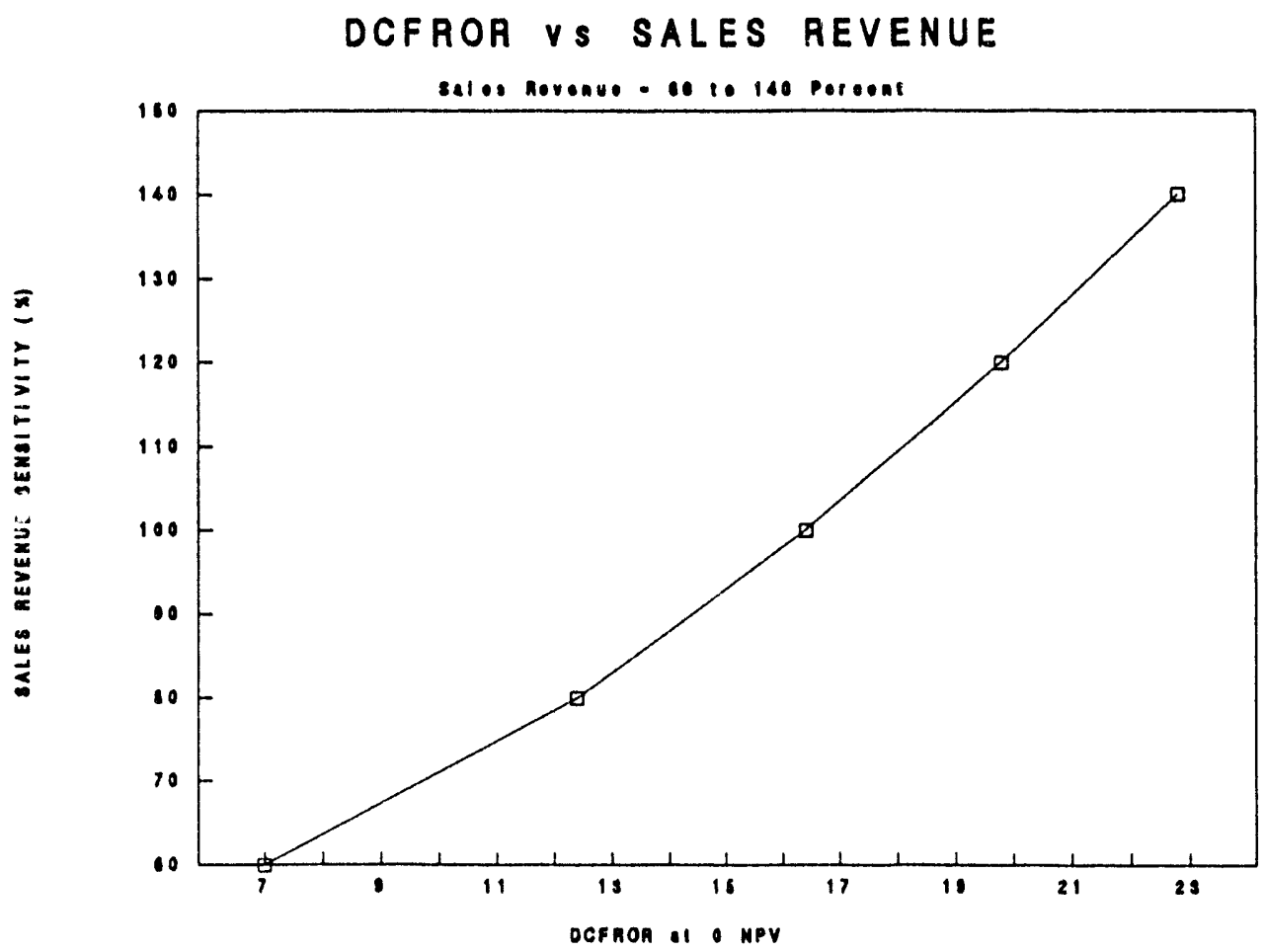

Figure 5. DCFROR sensitivity versus sales revenues. 
on the $X$-axis of the graph, while capital cost sensitivity is shown with the multiple curves. In terms of dollar value rather than percentages, a 20 percent change in capital equates to $\$ 34$ million, while a 20 percent change in revenue equals $\$ 8$ million.

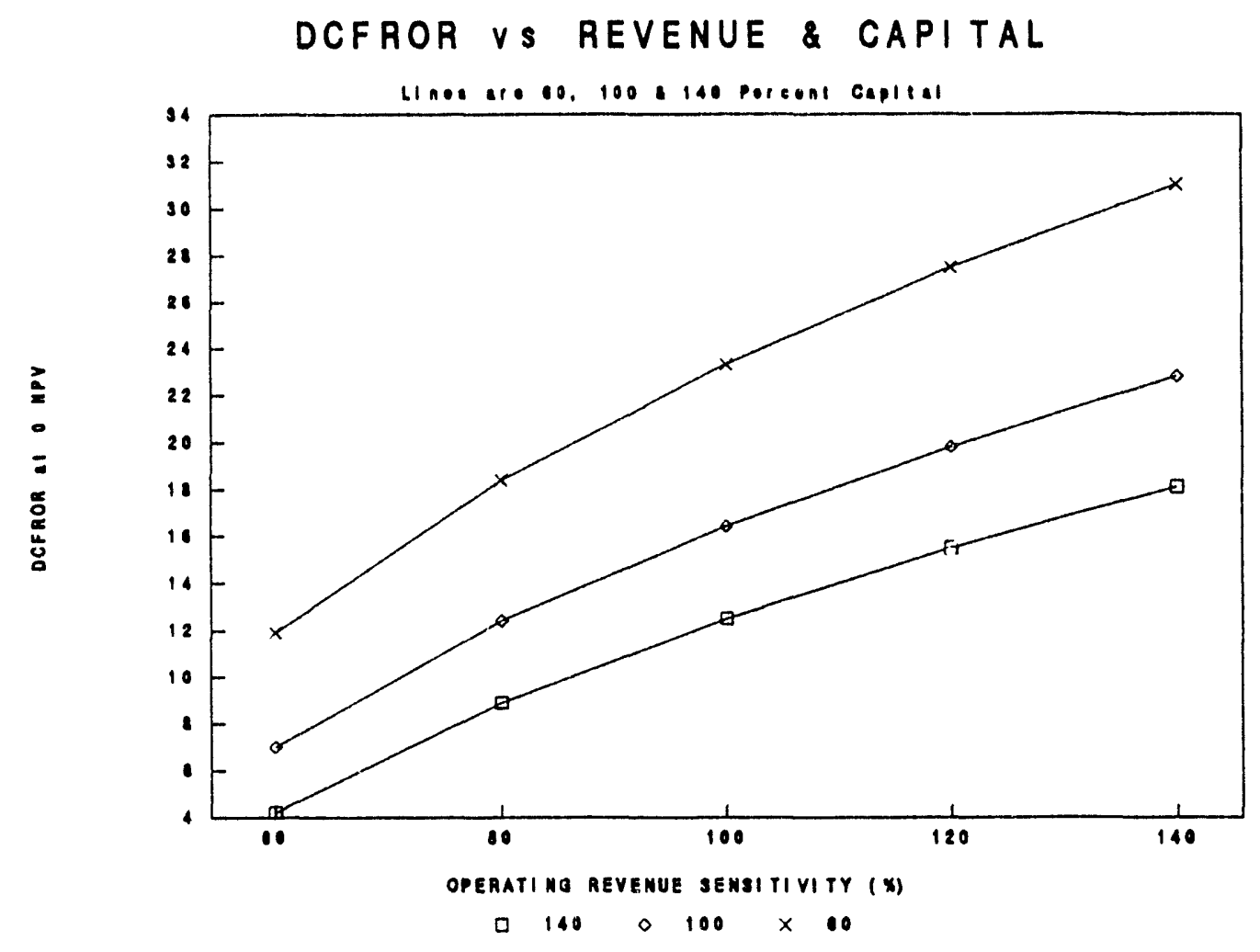

Figure 6. DCFROR sensitivity versus revenue and capital.

This graph shows a number of things, most noticeably that the project economics become marginal under a combination of high capital cost and low sales revenue. A combination of capital costs 40 percent higher than estimated for the base case and revenues 40 percent lower will result in an unacceptable project. Using a 10 percent DCFROR as a go/no go decision point indicates that projects costing 60 percent of the estimate will be acceptable at revenues down to about 55 percent of the base case estimate and assumptions. Projects having an actual capital cost equal to the estimate will be acceptable if revenues are about 75 percent of the base case, and if the project is at 140 percent of the base case capital estimate, revenues will have to be greater than 90 percent of the base case estimate. Other combinations can be evaluated from the graph, including those conditions necessary to achieve higher DCFROR values. 
The figure also shows the curvilinear relationship between both capital cost and operating revenue versus DCFROR. At low DCFROR values, it takes a greater dollar change to impact a percentage change in the DCFROR than it does at the higher DCFROR values. 


\section{SUMMARY AND CONCLUSIONS}

A 1,000 ton/day coal mild gasification and product upgrading commercial demonstration plant (CDP) was designed to produce several value-added products. The plant will be located at an AMAX coal mine near Gillette, Wyoming. The product slate includes pitch, cresylic acid, fuel oil, pure carbon, activated carbon, and electricity.

The CDP design is based on a proce is flowsheet developed and improved by WRI and AMAX over the last 3 years by bench-scale research and design, construction, operation, and evaluation of a 100 pound/hour mild gasification process research unit (PRU) at WRI and a companion char-to-carbon (CTC) PRU at AMAX. An adjunct power plant was assumed to be of conventional design.

The mild gasification process flowsheet as tested by WRI was slightly modified to improve the operability of the plant and recovery of the desired liquid products. The CTC process flowsheet was based on the AMAX PRU design with only one major change, and that is that the carbon reactor be heated by heat pipes instead of glow bars. Since the completion of the CDP design, it was learned that this design of the carbon reactor is not satisfactory and an alternative design has to be developed.

A process flowsheet and mass balance are included in the report. It is based on a more detailed design work performed on a 20 ton/day process development unit (PDU) encompassing the same unit operations. This also formed the basis for sizing of the reactors and estimation of the purchased equipment cost for the process plant. The estimated purchased equipment cost for the power plant was based on Parsons' experience.

There was a significant difference between the installation cost factors estimated by Parsons and by Stearns-Roger who had performed a similar study on the project in 1988. Amax R\&D evaluated the factor for each major equipment and selected the value considered more realistic for the project site.

The total capital cost for the plant is estimated at $\$ 169$ million ( $\$ 138$ million for the process plant and $\$ 31$ million for the power plant). This total includes a contingency of \$26 million. The annual operating cost in 1991 dollars is estimatec' at $\$ 11$ million, which includes $\$ 4$ million for labor, $\$ 4.2$ million for maintenance, and the balance for feedstock and supplies.

The estimated annual revenues are $\$ 30$ million for pure carbon, $\$ 11$ million for activated carbon, $\$ 7$ million for liquid products, and $\$ 11$ million for electricity, for a total of $\$ 59$ million. 
An economic evaluation model was used to calculate the DCFROR, assuming zero net present value and 20-year plant life. Sensitivity analysis was performed on the capital cost, operating cost, and product revenues. The DCFROR was 16.4 percent for the base case.

in summary, the project is technically sound and offers good economic potential for commercial development. 


\section{RECOMMENDATIONS}

Based on the economic potential for commercial development of this project, it is recommended that the project development efforts should continue.

The first step should be to solidify the technical basis of those steps that have not been successfully tested in the PRU operation. The most important ones are the liquid recovery system and the carbon reactor. This operation is also necessary for market evaluation of products, which has not yet been accomplished.

After these results become available, the economic evaluation of the 1,000 ton/day plant should be updated. At that time, it may be desirable to focus some effor on the power plant design.

Assuming the project continues to look attractive, the PDU should be designed, constructed, and operated in preparation for the design of the commercial demonstration plant. 


\section{REFERENCES}

1. Cha, C. Y., Merriam, N. W., Jha, M. C., and Breault, R. W., "Development of an Advanced, Continuous Mild Gasification Process for the Production of Coproducts", Topical Report for Task 1, Contract No. DE-AC21-87MC24268, Report No. DOE/MC/24268-2700 (DE890000967), June 1988.

2. "Engineering Evaluation \& Cost Estimate of an Advanced Continuous Mild Gasification Process", Stearns-Roger Division of United Engineers \& Constructors, Denver, Colorado, Report Prepared for Amax Research \& Development Center Under DOE/METC Contract No. DE-AC21-87MC24268, October 1988.

3. Merriam, N. W. and Cha, C. Y., "Development of an Advanced, Continuous Mild Gasification Process for the Production of Coproducts", Topical Report for Task 2, Mild Gasification Tests, Contract No. DE-AC21-87MC24268, Western Research Institute, Laramie, Wyoming, April 1989.

4. Jha, M. C. and McCormick, R. L., "Development of an Advanced, Continuous Mild Gasification Process for the Production of Coproducts", Topical Report for Task 3, Bench-Scale Char Upgrading and Utilization Study, Contract No. DE-AC21-87MC24268, Amax Research \& Development Center, Golden, Colorado, August 1989.

5. Merriam, N. W., Cha, C. Y., Kang, T. W., and Vaillancourt, M. B., "Development of an Advanced, Continuous Mild Gasification Process for the Production of Coproducts", Topical Report for Task 4, Mild' Gasification Tests, Contract No. DE-AC21-87MC24268, WRI Report No. WRI-91-R023, Western Research Institute, Laramie, Wyoming, December 1990.

6. McCormick, R. L., Rowe, R. M., Hogsett, R. F., Anast, K. R., and Jha, M. C., "Development of an Advanced, Continuous Mild Gasification Process for the Production of Coproducts", Topical Report for Task 4, System Integration Studies: Char Upgrading, Contract No. DE-AC21-87MC24268, Amax Research \& Development Center, Golden, Colorado, October 1991.

7. "Preliminary Engineering Design and Cost Estimate for a 20 Tons/Day Coal Mild Gasification and Product Upgrading Process Development Unit (PDU)", Topical Report for Task 4.7, Contract No. DE-AC21-87MC24268, Prepared by Amax Research \& Development Center, Golden, Colorado, and the Ralph M. Parsons Company, Pasadena, California, September 1991.

8. Jha, M. C. and Cha, C. Y., "Mild Gasification of Western Subbituminous Coal: Product Recovery and Upgrading", Proceedings of Sixth Annual International Pittsburgh Coal Conference, September 1989, pps. 765 - 774. 
9. Daw, C. S., Graves, R. L., Krishnan, R. P., West, B. H., Compere, A. L., and Griffith, W. L., "Mild Gasification Product Characterization - 1990 Results", Proceedings of the 10th Annual Gasification and Gas Stream Cleanup Systems Contractors Review Meeting, V. P. Kothari and J. L. Beeson, Editors, DOE Report DOE/METC-90/6115, Volume 2 (DE90009690), August 1990, pps. 509 - 518.

10. Daw, C. S., "Combustion Reactivity of Mild Gasification Chars", Proceedings of the 7th Annual International Pittsburgh Coal Conference, September 1990, p. 84.

11. Woessner, P. W. and Jha, M. C., "Coal Derived Pure Carbon: A Potential Premium Fuel for Industrial Power Generation", Paper Presented at the 1990 Industrial Power Conference, St. Louis, Missouri, October 2, 1990.

12. Jha, M. C., McCormick, R. L., and Berggren, M. H., "Upgrading of Coal Char from Mild Gasification", Proceedings of the 9th Annual Gasification and Gas Stream Cleanup Systems Contractors Review Meeting, R. A. Johnson and T. P. Dorchak, Editors, DOE Report DOE/METC-89/6107, Volume 1 (DE89011706), June 1989, pps. 349 - 358.

13. McCormick, R. L. and Jha, M. C., "Characterization of Mild Gasification Char for Methane Production", op. cit. pps. 103 - 112.

14. Jha, M. C., McCormick, R. L., and Hogsett, R. F., "Upgrading of Coal Char from Mild Gasification", Proceedings of the 10th Annual Gasification and Gas Stream Cleanup Systems Contractors Review Meeting, V. P. Kothari and J. L. Beeson, Editors, DOE Report DOE/METC-90/6115, Volume 2 (DE90009690), August 1990, pps. 572 - 581.

15. Frederick, J. P. and Siddoway, M. A., "ENCOAL Mild Gasification Project: Preliminary Plans", op. cit., pps. 563 - 571.

16. Ness, R. O., Jr., and Willson, W. G., "Development of an Advanced, Continuous Mild Gasification Process for the Production of Coproducts", op. cit., pps. 591 - 600 .

17. McCormick, R. L., Jha, M. C., and Hogsett, R. F., "A Continuous, Indirectly Heated Process for the Production of Carbon and Hydrogen from Hydrocarbons", U. S. Patent Application Serial No. 584,994.

18. Jha, M. C. and McCormick, R. L., "Process for the Manufacture of Activated Carbon from Coal by Mild Gasification and Hydrogenation", U. S. Patent Application Serial No. 571,794. 
19. Hogsett, R. F., McCormick, R. L., and Jha, M. C., "Char-to-Carbon (CTC) Process, Including an Intermediate Gas Separation Step", Record of Invention Submitted to DOE Patent Office, Oak Ridge, October 1990. 
APPENDIX A

DESIGN PARAMETERS 


\section{APPENDIX A \\ 1,000 TONS PER DAY MILD GASIFICATION AND PRODUCT UPGRADING \\ DESIGN BASIS PARAMETERS \\ June 4, 1991}

\section{SITE CONDITIONS}

A. Location: Belle Ayr Mine (Powder River Basin), Gillette, wyoming

B. Elevation (Gillette Chamber of Commerce -GCofC): 4,500 Ft (Atmos. Pressure 12.4 psia)

c. Climatic conditions, (GC of $C$ ):

Temperatures, ${ }^{\circ} \mathrm{F}$ : Maximum, 83; Minimum, 17; Average 45

Rainfall, Inches/Year: 15.75

Snowfall Inches/Year: 66

Relative Humidity, Percent: 45

Growing Season, days: 123

Wind, miles/hour: Assume 100

D. Available Utilities:

1. Air: $100 \mathrm{hp} / 100 \mathrm{psi}$ compressor

2. Water
a. Potable: BY AMAX
b. Sanitary:BY AMAX
c. Industrial: BY AMAX
d. Fire: BY AMAX

3. Steam/Condensate: Produced by process 
4. Natural Gas: Not available. Use purchased propane

5. Electrical: $470 / 208$ V 3 ph 60 Hertz

6. Sewers: TO AMAX mine wastewater treatment plant

7. Waste Disposal: 55 gallon drums and superbags 


\section{PROCESS DESIGN CRITERIA FOR THE MILD GASIFICATION}

(DRYING AND GASIFICATION) SECTION

PRIMARY PROCESS UNII'S

1. Pre Drying circuit

i. Equipment supplied by AMAX - Dryer and its delivery system outside the battery limits (OBL).

ii. Cambelt-type conveying system

iii. Ancillary Equipment

2. Drying circuit

i. Equipment Supplied by Tecogen

ii. Ancillary Equipment

3. Mild Gasifier

i. Equipment Supplied by Tecogen

ii. Other Equipment

4. Gas Systems

i. Dust Handling

ii. Pitch Production

iii. Oil production

iv. Cresylic Acid Extraction 


\section{TABULATED TECHNICAL INFORMATION USED IN THE DESIGN OF THE MILD GASIFICATION SECTION}

(Figures apply to Total Flows, not individual machines)

A. Dryer

1. Design Capacity

Feed $t / d: 800$ e $10 \%$ Moisture*

Char out Temp. ${ }^{\circ} \mathrm{F}: 400$

*equivalent to approximately $1,000 \mathrm{t} / \mathrm{d}$ ROM coal $\mathrm{e}+1-30 \%$ Moisture prior to initial drying

2. Coal Feed Composition (AMAX)

a. Proximate Analysis

$\begin{array}{lr}\text { Fixed Carbon } & 45.0 \text { Wt } 8 \\ \text { Volatile Matter } & 39.1 \\ \text { Moisture } & 10.0 \\ \text { Ash } & 5.9\end{array}$

b. Ultimate Analysis

$\begin{array}{lr}\text { Carbon } & 75.7 \text { Wt } 8 \\ \text { Hydrogen } & 4.4 \\ \text { Sulfur } & 0.4 \\ \text { Nitrogen } & 0.9 \\ \text { Oxygen } & 18.6\end{array}$


c. Coal Feed Analysis for Design Purposes

$\begin{array}{lc}\text { Carbon } & 63.66 \mathrm{Wt} \% \\ \text { Hydrogen } & 3.7 \\ \text { Sulfur } & 0.34 \\ \text { Nitrogen } & 0.76 \\ \text { Oxygen } & 15.64 \\ \text { Ash } & 5.9 \\ \text { Moisture } & 10.0\end{array}$

3. Size (AMAX)

Maximum Size: 1/8" ( 6 USS mesh)

Average Size: 28 USS mesh

Lower Size: Down to $2 \%-200$ USS mesh

4. Specific Heat : $0.35 \mathrm{Btu} / 1 \mathrm{~b}{ }^{\circ} \mathrm{F}$

Heating value $(A \max ): 11,500 \mathrm{Btu} / \mathrm{Lb}$

5. Density

Bulk Density: 43 to $47 \mathrm{lb} / \mathrm{Cf}$

6. Angle of Repose, degrees from the horizontal: 37

7. Operating Conditions

a. Coal Temperature, ${ }^{\circ} \mathrm{F}: 70$ in, 400 out

b. Fluidizing/Heating Gas Temperature Profile, ${ }^{\circ} \mathrm{F}: 481$ in, 261 out

c. Gas Fluidization Velocity, $\mathrm{ft}^{3} / \mathrm{hr}$ : 200,000 minimum, 300,000 , design 
8. Net Dryer Overhead (Basis: Topical Report for Task 4, WRI)

$\begin{array}{lc}\text { Fine Coal, } & 56.4 \mathrm{t} / \mathrm{d} \\ \text { Dust Coal } & 8.8 \\ \text { Water } & 80 \\ \mathrm{CO}_{2} & 6.6 \\ \mathrm{CO} & 0.1 \\ \mathrm{CH}_{4} & 0.1 \\ \text { Temperature, }{ }^{\circ} \mathrm{F} & 261\end{array}$

9. Composition of Dryer Heating Gas, Mole $\frac{}{6}$

$\begin{array}{lc}\mathrm{CO}_{2} & 15 \\ \mathrm{CO} & 0.5 \\ \mathrm{CH}_{4} & \mathrm{Tr} . \\ \mathrm{H}_{2} \mathrm{O} & 17 \\ \mathrm{O}_{2} & 0.8 \\ \mathrm{~N}_{2} & 66\end{array}$

$$
\begin{array}{lc}
\text { Specific Heat, Btu/lb }{ }^{\circ} \mathrm{F}: & 0.25 \\
\text { Heating Value, Btu/lb : } & 170 \\
\text { Bulk Density, 1b/cu ft : } & 0.08
\end{array}
$$

10. Dryer Product Compositions/Characteristics

$$
\text { Production of dry coal, } t / d \quad 648
$$

a. Proximate Analysis

$\begin{array}{lc}\text { Fixed Carbon } & 50 \text { Wt } \% \\ \text { Volatile Matter } & 43.4 \\ \text { Moisture } & 0 \\ \text { Ash } & 6.6\end{array}$


b. Ultimate Analysis, MAF

$\begin{array}{lr}\text { Carbon } & 75.7 \text { Wt } 8 \\ \text { Hydrogen } & 4.4 \\ \text { Sulfur } & 0.4 \\ \text { Nitrogen } & 0.9 \\ \text { Oxygen } & 18.6\end{array}$

c. Dried Coal Analysis for Design Purposes

$\begin{array}{lr}\text { Carbon } & 70.7 \text { Wt } \% \\ \text { Hydrogen } & 4.1 \\ \text { Sulfur } & 0.4 \\ \text { Nitrogen } & 0.8 \\ \text { Oxygen } & 17.4 \\ \text { Ash } & 6.6 \\ \text { Moisture } & 0\end{array}$

d. Size Analysis (AMAX)

$\begin{array}{lr}\text { Maximum size, } & 8 \text { USS sieve } \\ \text { Average } & 30 \text { USS Sieve } \\ \text { Lowest size } & 200 \text { to pan USS sieve }\end{array}$

B. MILD GASIFIER

1. Yields

$\begin{array}{rc}t / d & \text { Wt } \% \text { MG Feed Coal } \\ 390 & \\ 112 & 60.2 \\ 48 & 17.3 \\ 73 & 7.4 \\ 25 & 11.3 \\ 648 & 3.8\end{array}$


2. Products

a. Char

\section{Proximate Analysis}

Topical Report Task \#4

Weight $\%$

$\begin{array}{lr}\text { Moisture } & 0.00 \\ \text { Volatile } & 1.1 .00 \\ \text { Fixed Carbon } & 75.00 \\ \text { Ash } & 9.00\end{array}$

Ultimate Analysis

BEI FS Provided by AMAX

Weight $\%$

\section{Carbon}

Hydrogen

Nitrogen

sulfur

oxygen

Ash
77.51

2.12

1.12

0.45

9.8

9.0

Production Yield, 0.49 Lb Char/ $1 \mathrm{~b}$ of $10 \%$ Moisture Feed coal, equivalent to 650 ib of char per hou...

Temperature, ${ }^{\circ} \mathrm{F} \quad 1100$ 


\section{Analysis Used For Design}

\section{Weignt 8}

$\begin{array}{lr}\text { Carbon } & 77.5 \\ \text { Hydrogen } & 2.1 \\ \text { Nitrogen } & 1.1 \\ \text { Sulfur } & 0.5 \\ \text { Oxygen } & 9.8 \\ \text { Ash } & 9.0\end{array}$

b. Composition of Net Effluent Gases (Basis: Topical Report for Task 4, WRI)

Make Gas Composition, Weight $\%$

$\begin{array}{lc}\mathrm{CO}_{2} & 41 \\ \mathrm{CO} & 19.2 \\ \mathrm{CH}_{4} & 20.4 \\ \mathrm{C}_{2} \mathrm{H}_{6} & 5 \\ \mathrm{H}_{2} & 1 \\ \mathrm{H}_{2} \mathrm{~S} & 0.1 \\ \text { Oil input } & 13.3\end{array}$

c. Gas Composition of M:Id Gasifier Heating Gas, Mole $\frac{z}{8}$

$\begin{array}{lr}\mathrm{CO}_{2} & 15.6 \\ \mathrm{CO} & 0.5 \\ \mathrm{H}_{2} \mathrm{O} & 18.8 \\ \mathrm{O}_{2} & 0.8 \\ \mathrm{~N}_{2} & 64.3\end{array}$

Specific Heat: $0.32 \mathrm{Btu} / \mathrm{lb}{ }^{\circ} \mathrm{F}$ e $1150^{\circ} \mathrm{F}$

Bulk Density: $0.08 \mathrm{lb} / \mathrm{cu} \mathrm{ft}$ 
3. Angle of Repose, degrees from the horizontal: 37

4. Operating Conditions

a. Coal Temperature Profile, ${ }^{\circ} \mathrm{F}: 400 \mathrm{in,} 1100$ out

b. Heating Gas Temperature Profile, ${ }^{\circ} \mathrm{F}$ : 1264 in, 1041 out

c. Gas Fluidization Velocity, $\mathrm{ft}^{3} / \mathrm{hr}$ :

3,300 minimum; 5,000 design

5. Oil Products

a. Composition Basis: Topical Report for Task 4, WRI, Table 24 Test 118):

$\begin{array}{lr}\text { Carbon } & 81.7 \text { Wt } 8 \\ \text { Hydrogen } & 7.9 \\ \text { Sulfur } & 0.7 \\ \text { Nitrogen } & 0.5 \\ \text { Oxygen } & 8.9\end{array}$

b. HHV, Btu/Ib: 19,000 
c. Boiling Range (Topical Report for Task 4, WRI) Liquids, Moisture Free

$\begin{array}{lc}\text { Boiling Range } & \text { \& Weight } \\ \text { 200- } 300 & 0.8 \\ 300-400 & 4.4 \\ 400-500 & 10.2 \\ 500-600 & 12.3 \\ 600-700 & 10 \\ 700-800 & 10.5 \\ 800-900 & 8.3 \\ 900-1000 & 3.5 \\ \text { Residue } & 39.8 \\ & \\ \text { Total (ASTM D2887) } & 99.8 \\ \text { Pitch } & \\ \text { Weight } \& \text { of } 10 \% \text { moisture feed coal } 12.3 \\ \text { lb/hr } \\ \text { t/d }\end{array}$

Light oil

Weight $\%$ of $10 \%$ moisture feed coal 3.2 $1 \mathrm{~b} / \mathrm{hr}$

$t / d$

42.8

0.51 
III. PROCESS DESIGN CRITERIA FOR THE CHAR TO CARBON SECTION

\section{PRIMARY PROCESS UNITS}

1. Char to Methane Reaction

i. Reactor

ii. Solids Charge \& Discharge

iii. Heat Removal

2. Methane to Carbon Reaction

i. Reactor

ii. Carbon Discharge

iii. Heat Supply

3. Gas circulation

i. Separation -- Semipermeable Membrane

ii. Compression

4. Gasifier

5. Power Plant

TABULATED TECHNICAL INFORMATION USED IN THE DESIGN OF THE CHAR TO CARBON SECTION

(Figures apply to Total flows, not individual items) 
A. Char to Methane Reaction

1. Char

$\begin{array}{ll}\text { Weight } & \begin{array}{c}\text { Percent } \\ \text { Percent }\end{array} \\ \text { Conversion }\end{array}$

Carbon

77.5

75

Hydrogen

2.1

82

Nitrogen

1.1

93

sulfur

0.5

42

oxygen

9.8

90

Ash

9.0

0

Total Feed Rate

$390.0 t / d$

2. Char-To-Methane Reactor

Type: Four fluidized beds - stacked

operating Temperature, ${ }^{\circ} \mathrm{F}$ : 1382

Pressure, psia: 320

Heat Removal/Bed Temperature Control by Generation of 970 psia steam, 73MMBtu/Hr 
3. Process Gas

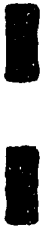

$\mathrm{CO}_{2}$

CO

Feed Gas

Off Gas

Mol. 8

Mol \&

$\mathrm{CH}_{4}$

$\mathrm{H}_{2} \mathrm{O}$

$\mathrm{H}_{2}$

$\mathrm{N}_{2}$

$\mathrm{H}_{2} \mathrm{~S}$

0.00

0.12

0.77

1.15

2 .

40.91

0.08

4.12

96.67

52.73

0.48

0.92

0.00

0.05

MSCFH

2090

1598

Temp., ${ }^{\circ} \mathrm{F}$

1247

1321

Pressure, psia

323

320

B. Methane to Carbon Reaction

1. Carbon Forming Reactor

Type: Single fluidized bed in each of four parallel reactors

Operating Temperature, ${ }^{\circ} \mathrm{F}$ : 1650

Pressure, psia: 100

Continuous heat supplied via 2,000 heat pipes

Medium: Sodium Metal $100 \mathrm{MmBtu} / \mathrm{Hr}$ 
2. Process Gas

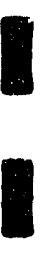

9

$\mathrm{CO}_{2}$

$\mathrm{CO}$

$\mathrm{CH}_{4}$

$\mathrm{H}_{2} \mathrm{O}$

$\mathrm{H}_{2}$

$\mathrm{N}_{2}$

$\mathrm{H}_{2} \mathrm{~S}$

Feed Gas

Mol. 8

Off Gas

Mol $f$

MSCFH
Temp., of
Pressure, psia

0.01

0.03

9.52

7.86

51.91

24.13

0.52

0.29

31.94

62.71

6.1

4.98

0.00

0.00

I

,

Pressure, psia

2651
1200
100

3248

1651

100

3. Product

Carbon Black, Pure C 216 t/d 
c. Gas circulation

1. Gas Separation - Semi-Permeable Membrane

Membrane

Feed

Combined

Product

Effluents

Mol of

\begin{tabular}{ccc} 
High & High & \\
Methane & Hydrogen & \\
to CFR & to TTMR & Recovery \\
Mol 8 & Mol $\%$ & Percent \\
\hline
\end{tabular}

$\mathrm{CO}_{2}$

0.004

0.007

0.00

$\mathrm{CO}$

5.68

9.52

0.72

$\mathrm{CH}_{4}$

30.18

51.91

1.94

$\mathrm{H}_{2} \mathrm{O}$

0.33

0.52

0.08

$\mathrm{H}_{2}$

60.15

31.94

96.80

70

$\mathrm{N}_{2}$

3.66

6.1

0.46

$\mathrm{H}_{2} \mathrm{~S}$

0.00

0.00

0.00

MSCFH

Temp., ${ }^{\circ} \mathrm{F}$

Pressure, psia
4685

196

319
2651

196

225
2038

196

100 
2. Bleed and Recovery of Hydrogen from Purge

\begin{tabular}{lll} 
Bleed & $\begin{array}{l}\text { Recovered } \\
\text { Mol\% }\end{array}$ & $\begin{array}{l}\text { Mol } \% \\
\text { Hydrogen } \\
\text { Mol \% }\end{array}$ \\
\hline
\end{tabular}

$\begin{array}{lrcr}\mathrm{CO}_{2} & 0.03 & 0.06 & 0.00 \\ \mathrm{CO} & 7.86 & 14.05 & 2.62 \\ \mathrm{CH}_{4} & 24.13 & 48.4 & 3.57 \\ \mathrm{H}_{2} \mathrm{O} & 0.29 & 0.64 & 0.00 \\ \mathrm{H}_{2} & 62.71 & 27.35 & 92.66 \\ \mathrm{~N}_{2} & 4.98 & 9.5 & 1.15 \\ \mathrm{H}_{2} \mathrm{~S} & 0.00 & 0.00 & 0.00\end{array}$

$\begin{array}{lrrr}\text { MSCFH } & 98 & 45 & 53 \\ \text { Temp., }{ }^{\circ} \mathrm{F} & 196 & 196 & 196 \\ \text { Pressure, psia } & 319 & 225 & 100\end{array}$




\section{APPENDIX B}

PROCESS FLOW DIAGRAM AND MATERIAL BALANCE 


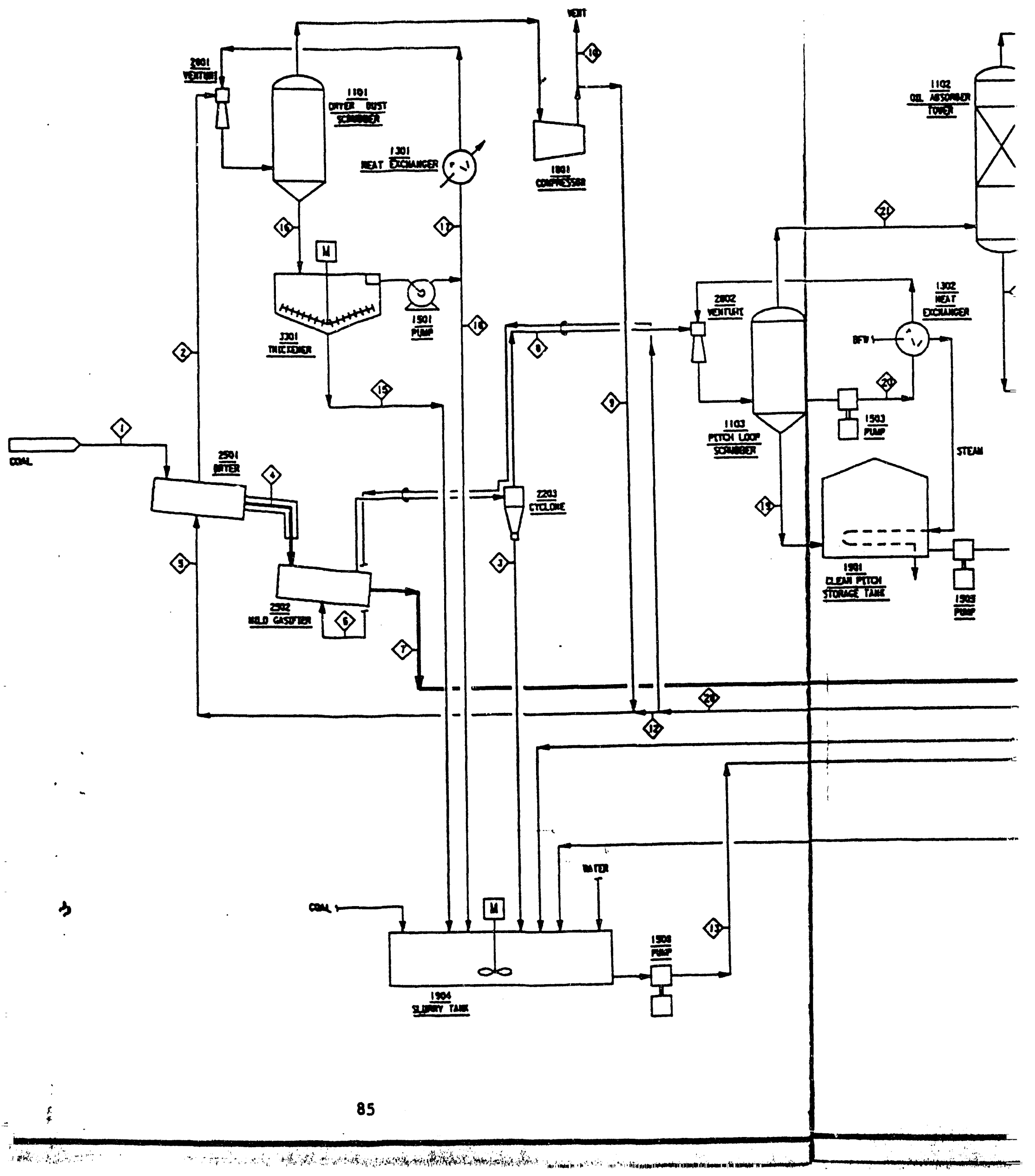




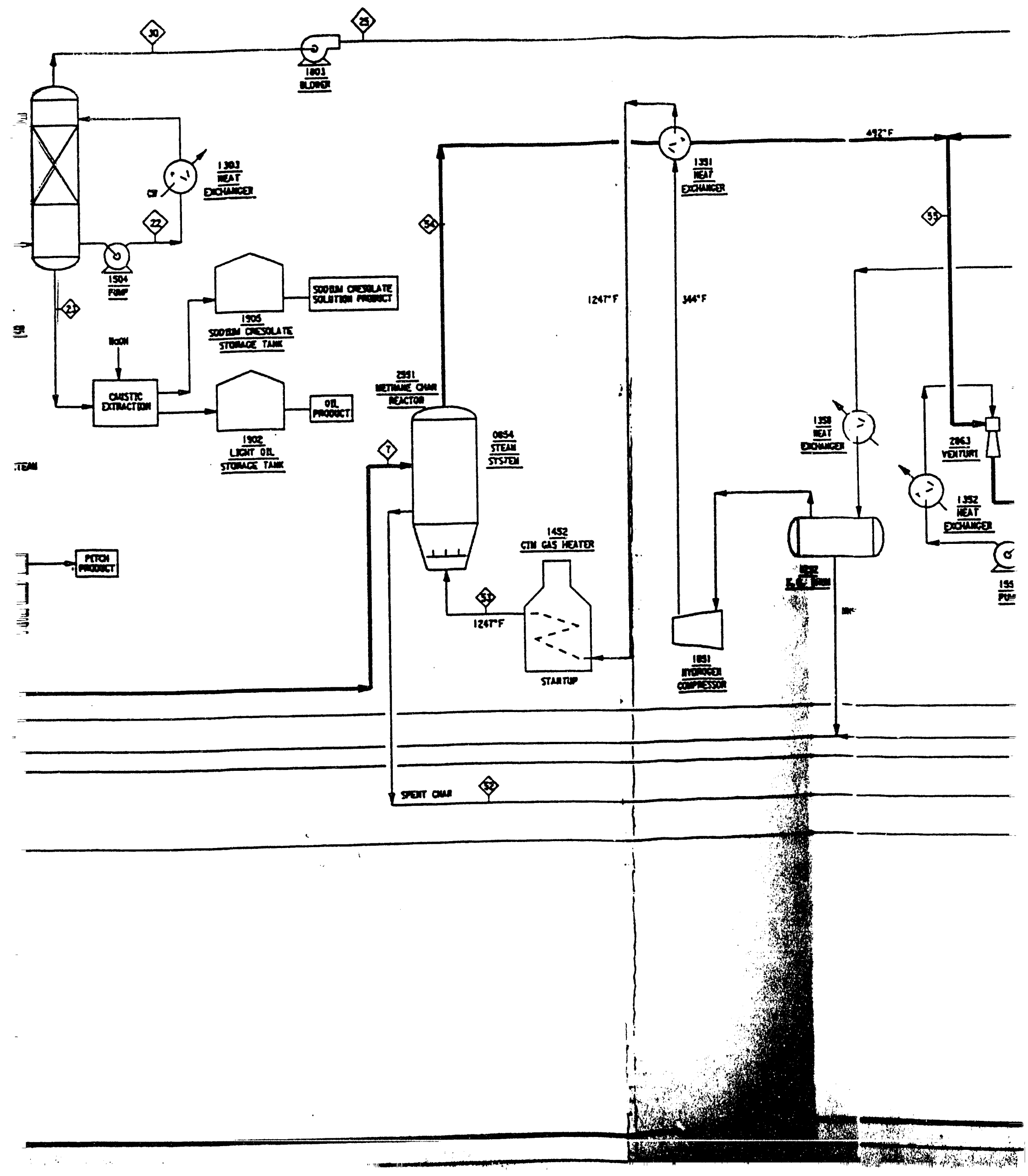




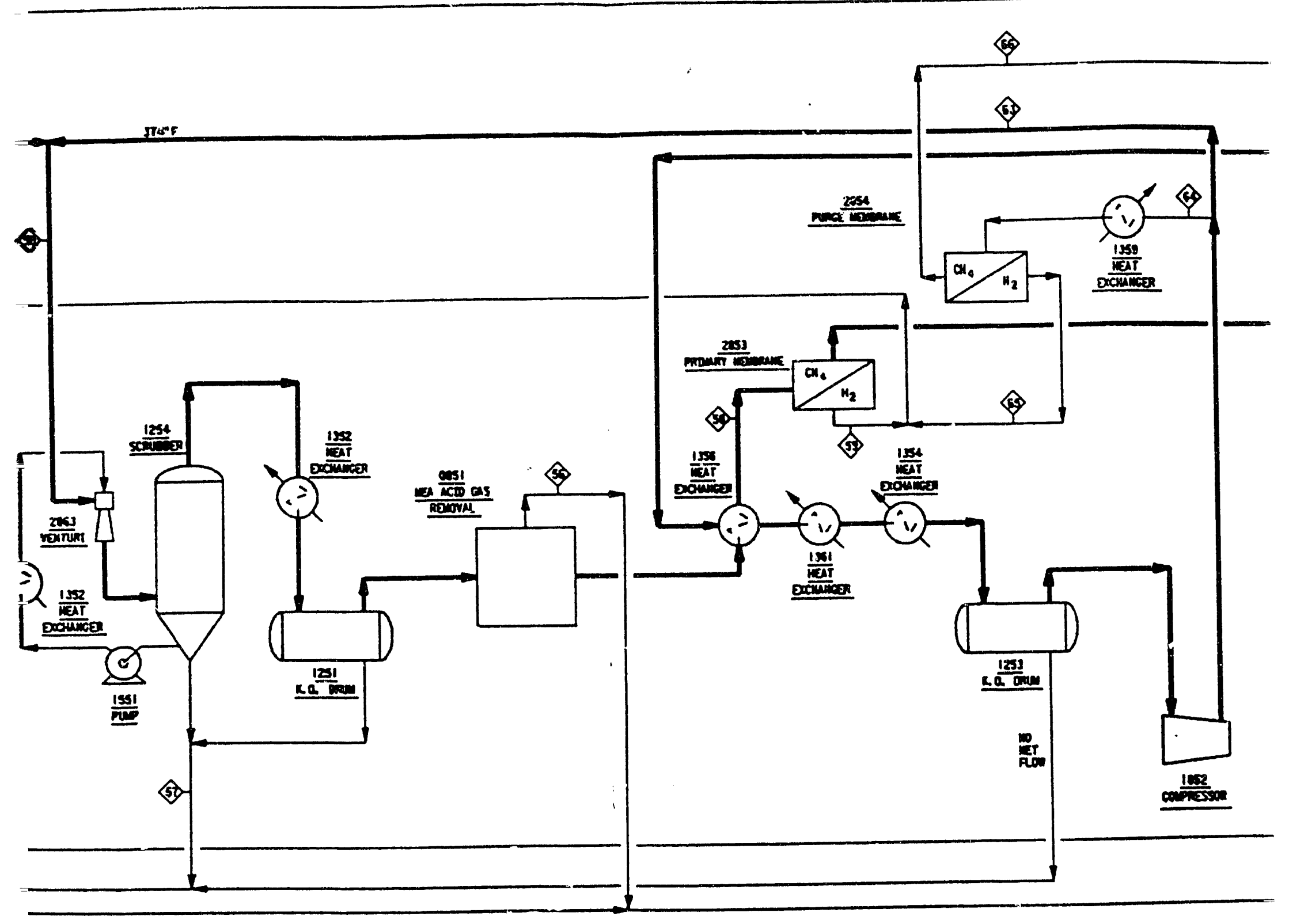




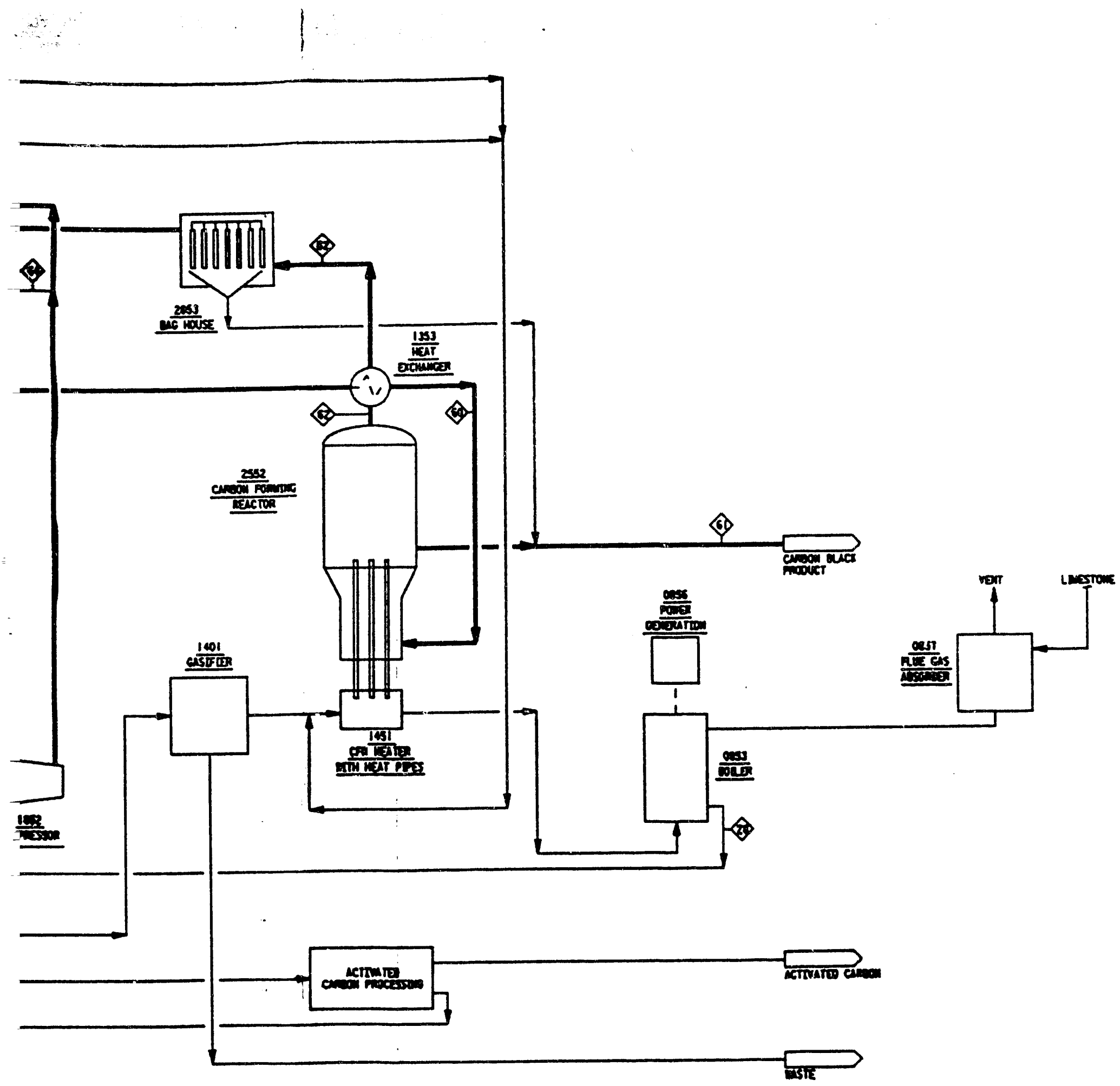

neanaxi.p

$$
=
$$


Section 4

Table 4-1

1000 T/D WYCOR Project

Material Balance

\begin{tabular}{|c|c|c|c|c|c|}
\hline Stream Number & 1 & 2 & 3 & 4 & 5 \\
\hline Description & $\begin{array}{l}\text { Feed } \\
\text { Coal }\end{array}$ & $\begin{array}{c}\text { Dirty } \\
\text { Dryer } \\
\text { Gas }\end{array}$ & $\begin{array}{l}\text { Fines } \\
\text { from } \\
\text { M.G. }\end{array}$ & $\begin{array}{l}\text { Coal } \\
\text { Feed } \\
\text { to M.G. }\end{array}$ & $\begin{array}{l}\text { Gas } \\
\text { to Dryer }\end{array}$ \\
\hline Total flow, $t / h r$ & 33.433 & 131.575 & 1.040 & 27.015 & 125.150 \\
\hline Enthalpy, MMBtu/hr & -113.6 & -397.5 & -6.6 & -38.7 & -322.5 \\
\hline Pressure, psig & 12 & 7 & 7 & 12 & 12 \\
\hline Temperature, ${ }^{\circ} \mathrm{F}$ & 70 & 261 & 1,041 & 400 & 481 \\
\hline Density, Ib/cf & 47 & 0.08 & 27.5 & 47 & 0.08 \\
\hline \multicolumn{6}{|l|}{ Composition (mole fraction) } \\
\hline $\mathrm{CO}_{2}$ & $\cdot$ & 0.15 & - & - & 0.16 \\
\hline $\mathrm{CO}$ & - & 0.0049 & - & - & 0.005 \\
\hline $\mathrm{CH}_{4}$ & - & 0.0072 & - & - & 0.007 \\
\hline $\mathrm{H}_{2} \mathrm{O}$ & 1 & 0.16 & - & - & 0.13 \\
\hline $\mathrm{C}_{2} \mathrm{H}_{6}$ & - & 0.00096 & - & - & 0.001 \\
\hline $\mathrm{H}_{2}$ & $\cdot$ & 0.003 & - & - & 0.003 \\
\hline $\mathrm{O}_{2}$ & $\cdot$ & 0.008 & - & - & 0.008 \\
\hline $\mathrm{N}_{2}$ & - & 0.66 & - & - & 0.69 \\
\hline Sulfur compounds & - & 0.00017 & - & - & 0.00018 \\
\hline Oil & - & 0.00024 & - & - & 0.00022 \\
\hline Gas Mscfh & - & $3,394.5$ & - & - & $3,249.0$ \\
\hline Liquid, gpm & - & - & - & - & - \\
\hline Solid, $\mathrm{t} / \mathrm{hr}$ & 30.090 & 2.785 & 1.040 & 27.015 & - \\
\hline Molecular weight, fluids & - & 28.76 & - & - & 29.2 \\
\hline
\end{tabular}


Table 4-1 (Contd)

\begin{tabular}{|c|c|c|c|c|c|}
\hline Stream Number & 6 & 7 & 8 & 9 & 10 \\
\hline Description & $\begin{array}{l}\text { Heating } \\
\text { Gas } \\
\text { to M.G. }\end{array}$ & $\begin{array}{l}\text { Char } \\
\text { from } \\
\text { M.G. }\end{array}$ & $\begin{array}{l}\text { Feed to } \\
\text { Pitch } \\
\text { Scrubber }\end{array}$ & $\begin{array}{c}\text { Dryer } \\
\text { Gas } \\
\text { Recycle }\end{array}$ & $\begin{array}{l}\text { Dryer } \\
\text { Gas } \\
\text { Vent }\end{array}$ \\
\hline Total flow, t/hr & 120.000 & 16.250 & 129.700 & 95.925 & 27.700 \\
\hline Enthalpy, MMBtu/hr & -292.5 & 14.4 & -339.0 & -251.5 & -73.0 \\
\hline Pressure, psig & 12 & 12 & 7 & 12 & 12 \\
\hline Temperature, ${ }^{\circ} \mathrm{F}$ & 1,264 & 1,100 & 1,041 & 208 & 208 \\
\hline Density, Ib/cf & 0.08 & 34.5 & 0.08 & 0.08 & 0.08 \\
\hline \multicolumn{6}{|c|}{ Composition (mole fraction) } \\
\hline $\mathrm{CO}_{2}$ & 0.14 & - & 0.14 & 0.165 & 0.165 \\
\hline $\mathrm{CO}$ & 0.005 & - & 0.01 & 0.005 & 0.005 \\
\hline $\mathrm{CH}_{4}$ & 0.007 & - & 0.02 & 0.008 & 0.008 \\
\hline $\mathrm{H}_{2} \mathrm{O}$ & 0.188 & - & 0.1957 & 0.107 & 0.107 \\
\hline $\mathrm{C}_{2} \mathrm{H}_{6}$ & 0.00094 & - & 0.003 & 0.001 & 0.001 \\
\hline $\mathrm{H}_{2}$ & 0.003 & - & 0.008 & 0.003 & 0.003 \\
\hline $\mathrm{O}_{2}$ & 0.008 & - & 0.007 & 0.009 & 0.009 \\
\hline $\mathrm{N}_{2}$ & 0.64 & - & 0.605 & 0.702 & 0.702 \\
\hline Sulfur compounds & 0.00017 & - & 0.00021 & 0.00018 & 0.00018 \\
\hline Oil & 0.0014 & - & 0.0038 & 0.00008 & 0.00008 \\
\hline Gas Mscfh & $3,203.0$ & - & $3,402.0$ & $2,473.0$ & 714.0 \\
\hline Liquid, gpm & - & - & - & - & - \\
\hline Solid, $\mathrm{t} / \mathrm{hr}$ & - & 16.250 & 0.003 & - & - \\
\hline Molecular weight, fluids & 28.4 & - & 28.9 & 29.4 & 29.4 \\
\hline
\end{tabular}


Table 4-1 (Contd)

\begin{tabular}{|c|c|c|c|c|c|}
\hline Stream Number & 12 & 13 & 15 & 16 & 17 \\
\hline Description & $\begin{array}{l}\text { Heating } \\
\text { Gas to } \\
\text { Dryer }\end{array}$ & $\begin{array}{c}\text { Slurry } \\
\text { Tank } \\
\text { Product }\end{array}$ & $\begin{array}{l}\text { Thickener } \\
\text { Underflow }\end{array}$ & $\begin{array}{l}\text { Water } \\
\text { Scrubber } \\
\text { Underflow }\end{array}$ & $\begin{array}{c}\text { Water } \\
\text { Scrubber } \\
\text { Cooler } \\
\text { Water }\end{array}$ \\
\hline Total flow, $\mathrm{t} / \mathrm{hr}$ & 29.225 & 13.195 & 6.265 & 299.950 & 292.000 \\
\hline Enthalpy, MMBtu/hr & -71.0 & - & -67.5 & - & - \\
\hline Pressure, psig & 12 & - & 3 & 3 & 3 \\
\hline Temperature, ${ }^{\circ} \mathrm{F}$ & 1,264 & - & 131 & 131 & 131 \\
\hline Density, lb/cf & 0.08 & 66 & 66 & 62.4 & 62.4 \\
\hline \multicolumn{6}{|c|}{ Composition (mole fraction) } \\
\hline $\mathrm{CO}_{2}$ & 0.14 & 0.01 & - & - & - \\
\hline $\mathrm{CO}$ & 0 & - & - & - & - \\
\hline $\mathrm{CH}_{4}$ & 0.007 & - & - & - & - \\
\hline $\mathrm{H}_{2} \mathrm{O}$ & 0.188 & 0.99 & 1 & 1 & 1 \\
\hline $\mathrm{C}_{2} \mathrm{H}_{6}$ & 0.0009 & - & $\cdot$ & - & - \\
\hline $\mathrm{H}_{2}$ & 0.0003 & - & - & - & - \\
\hline $\mathrm{O}_{2}$ & 0.0008 & - & - & - & - \\
\hline $\mathrm{N}_{2}$ & 0.643 & - & - & - & - \\
\hline Sulfur compounds & 0.00016 & - & - & - & - \\
\hline Oil & 0.0007 & - & - & - & - \\
\hline Gas Mscfh & 780.0 & - & - & - & - \\
\hline Liquid, gpm & - & 27.5 & 13.0 & $1,187.5$ & $1,167.0$ \\
\hline Solid, $\mathrm{t} / \mathrm{hr}$ & - & 5.938 & 2.785 & 2.785 & - \\
\hline Molecular weight, fluids & 28.4 & 18.3 & 18.02 & 18.02 & 18.02 \\
\hline
\end{tabular}


Table 4-1 (Contd)

\begin{tabular}{|c|c|c|c|c|c|}
\hline Stream Number & 18 & 19 & 20 & 21 & 22 \\
\hline Description & $\begin{array}{l}\text { Excess } \\
\text { Scrubber } \\
\text { Water }\end{array}$ & $\begin{array}{c}\text { Pitch } \\
\text { Product }\end{array}$ & $\begin{array}{c}\text { Pitch } \\
\text { Scrubber } \\
\text { Recycle }\end{array}$ & $\begin{array}{c}\text { Pitch } \\
\text { Scrubber } \\
\text { Overhead }\end{array}$ & $\begin{array}{c}\text { Oil } \\
\text { Scrubber } \\
\text { Oil }\end{array}$ \\
\hline Total flow, t/hr & 1.675 & 1.938 & 362.500 & 127.775 & 815.525 \\
\hline Enthalpy, MMBtu/hr & -20.8 & 0.3 & 59.05 & -393.5 & -226.5 \\
\hline Pressure, psig & 3 & 4 & 4 & 4 & 4 \\
\hline Temperature, ${ }^{\circ} \mathrm{F}$ & 131 & 430 & 430 & 380 & 225 \\
\hline Density, Ib/cf & 62.4 & 89 & 89 & 0.08 & 59 \\
\hline \multicolumn{6}{|c|}{ Composition (mole fraction) } \\
\hline $\mathrm{CO}_{2}$ & 0.01 & 0.0002 & 0.0002 & 0.146 & 0.0007 \\
\hline Co & - & 0.0001 & 0.0001 & 0.01 & 0.00007 \\
\hline $\mathrm{CH}_{4}$ & - & 0.0001 & 0.0001 & 0.02 & 0.00008 \\
\hline $\mathrm{H}_{2} \mathrm{O}$ & 0.99 & 0.02 & 0.02 & 0.196 & 0.158 \\
\hline $\mathrm{C}_{2} \mathrm{H}_{6}$ & - & 0.000007 & 0.000007 & 0.002 & 0.00003 \\
\hline $\mathrm{H}_{2}$ & - & 0.00003 & 0.00003 & 0.008 & 0.000016 \\
\hline $\mathrm{O}_{2}$ & $\cdot$ & 0.00004 & 0.00004 & 0.007 & 0.00003 \\
\hline $\mathrm{N}_{2}$ & $\cdot$ & 0.004 & 0.004 & 0.606 & 0.002 \\
\hline Sulfur compounds & - & 0.000004 & 0.000004 & 0.00021 & 0.0008 \\
\hline Oil & $\cdot$ & 0.97 & 0.97 & 0.003 & 0.84 \\
\hline Gas Mscfh & - & - & - & $3,398.5$ & . - \\
\hline Liquid, gpm & 6.5 & 5.5 & $1,015.5$ & - & $3,446.5$ \\
\hline Solid, t/hr & - & 0.003 & - & - & - \\
\hline Molecular weight, fluids & 18.32 & 528 & 528 & 28.5 & 204 \\
\hline
\end{tabular}


Table 4-1 (Contd)

\begin{tabular}{|c|c|c|c|c|c|}
\hline Stream Number & 23 & 25 & 28 & 30 & 52 \\
\hline Description & $\begin{array}{c}\text { Oil } \\
\text { Product }\end{array}$ & $\begin{array}{l}\text { Final } \\
\text { Gas } \\
\text { to Fuel }\end{array}$ & $\begin{array}{l}\text { Total } \\
\text { Heating } \\
\text { Gas }\end{array}$ & $\begin{array}{c}\text { Oil } \\
\text { Scrubber } \\
\text { Overhead }\end{array}$ & $\begin{array}{l}\text { Spent } \\
\text { Char }\end{array}$ \\
\hline Total flow, t/hr & 1.070 & 126.700 & 149.225 & 126.700 & 4.894 \\
\hline Enthalpy, MMBtu/hr & -0.3 & -394.5 & -364.5 & -394.5 & - \\
\hline Pressure, psig & 12 & 12 & 12 & 12 & - \\
\hline Temperature, ${ }^{\circ} \mathrm{F}$ & 225 & 369 & 1,264 & 369 & 120 \\
\hline Density, Ib/cf & 59 & 0.08 & 0.08 & 0.08 & 23 \\
\hline \multicolumn{6}{|c|}{ Composition (mole fraction) } \\
\hline $\mathrm{CO}_{2}$ & 0.0007 & 0.146 & 0.15 & $0 .: 46$ & - \\
\hline co & 0.00007 & 0.01 & 0.005 & 0.01 & - \\
\hline $\mathrm{CH}_{4}$ & 0.00008 & 0.02 & 0.007 & 0.02 & - \\
\hline $\mathrm{H}_{2} \mathrm{O}$ & 0.158 & 0.916 & 0.188 & 0.916 & - \\
\hline $\mathrm{C}_{2} \mathrm{H}_{6}$ & 0.00003 & 0.00258 & 0.0009 & 0.00258 & - \\
\hline $\mathrm{H}_{2}$ & 0.000016 & 0.008 & 0.003 & 0.008 & - \\
\hline $\mathrm{O}_{2}$ & 0.00003 & 0.007 & 0.008 & 0.007 & - \\
\hline $\mathrm{N}_{2}$ & 0.002 & 0.606 & 0.643 & 0.606 & - \\
\hline Sulfur compounds & 0.0008 & 0.00021 & 0.00016 & 0.00021 & - \\
\hline Oil & 0.84 & 0.0022 & 0.00083 & 0.0022 & - \\
\hline Gas Mscfh & - & 3393.5 & $3,983.0$ & $3,393.5$ & - \\
\hline Liquid, gpm & 4.5 & - & - & - & - \\
\hline Solid, $\mathrm{t} / \mathrm{hr}$ & - & - & - & - & 4.824 \\
\hline Molecular weight, fluids & 233 & 28.3 & 28.4 & 28.3 & - \\
\hline
\end{tabular}


Table 4-1 (Contd)

\begin{tabular}{|c|c|c|c|c|c|}
\hline Stream Number & 53 & 54 & 55 & 56 & 57 \\
\hline Description & $\begin{array}{c}\text { CTM } \\
\mathrm{H}_{2} \text { Feed }\end{array}$ & $\begin{array}{l}\text { CTM } \\
\text { Hot Gas } \\
\text { Product }\end{array}$ & $\begin{array}{l}\text { Scrubber } \\
\text { Feed }\end{array}$ & $\begin{array}{l}\text { Acid } \\
\text { Gas }\end{array}$ & $\begin{array}{c}\text { Water } \\
\text { Knockout }\end{array}$ \\
\hline Total flow, $\mathrm{t} / \mathrm{hr}$ & 7.025 & 18.381 & 53.741 & 0.178 & 1.372 \\
\hline Enthalpy, MMBtu/hr & 23.57 & -24.62 & -129.29 & - & -2.17 \\
\hline Pressure, psig & 311 & 309 & 303 & - & 298 \\
\hline Temperature, ${ }^{\circ} \mathrm{F}$ & 1,247 & 1,321 & 443.6 & 194.4 & 100 \\
\hline Density, lb/cf & 0.0622 & 0.1552 & 0.2828 & - & 62.3 \\
\hline \multicolumn{6}{|c|}{ Composition (mole fraction) } \\
\hline $\mathrm{CO}_{2}$ & - & 0.0012 & 0.0006 & 0.7782 & - \\
\hline $\mathrm{CO}$ & 0.0077 & 0.0115 & 0.0560 & - & - \\
\hline $\mathrm{CH}_{4}$ & 0.0200 & 0.4091 & 0.2978 & - & - \\
\hline $\mathrm{H}_{2} \mathrm{O}$ & 0.0008 & 0.0412 & 0.0158 & - & 1.0000 \\
\hline $\mathrm{C}_{2} \mathrm{H}_{6}$ & - & - & - & - & - \\
\hline $\mathrm{H}_{2}$ & 0.9667 & 0.5274 & 0.5935 & - & - \\
\hline $\mathrm{O}_{2}$ & • & - & - & - & - \\
\hline $\mathbf{N}_{2}$ & 0.0048 & 0.0092 & 0.0362 & - & - \\
\hline Sulfur compounds & - & 0.0005 & 0.0002 & 0.2218 & - \\
\hline Oil & $\cdot$ & - & - & - & - \\
\hline Gas Mscfh & 2,090 & 1,598 & 4,748 & 3 & - \\
\hline Liquid, gpm & - & - & - & - & 5.6 \\
\hline Solid, t/hr & - & - & - & - & - \\
\hline Molecular weight, fluids & 2.634 & 9.0156 & 8.8717 & 41.8074 & 18.0154 \\
\hline
\end{tabular}


Table 4-1 (Contd)

\begin{tabular}{|c|c|c|c|c|c|}
\hline Stream Number & 58 & 59 & 60 & 61 & 62 \\
\hline Description & $\begin{array}{c}\text { Reheated } \\
\text { Membrane } \\
\text { Feed }\end{array}$ & $\begin{array}{c}\text { Separated } \\
\text { Hydrogen } \\
\text { Reactor }\end{array}$ & $\begin{array}{c}\text { Carbon } \\
\text { Reactor } \\
\text { Feed }\end{array}$ & $\begin{array}{l}\text { Carbon } \\
\text { Black }\end{array}$ & $\begin{array}{l}\text { Carbon } \\
\text { Reactor } \\
\text { Off-Gas }\end{array}$ \\
\hline Total flow, t/hr & 52.191 & 6.782 & 45.480 & 9.000 & 36.454 \\
\hline Enthalpy, MMBtu/hr & -148.90 & -16.60 & -63.84 & - & 26.02 \\
\hline Pressure, psig & 288 & 88 & 91 & - & 88 \\
\hline Temperature, ${ }^{\circ} \mathrm{F}$ & 196 & 202 & 1,200 & 120 & 1,652 \\
\hline Density, Ib/cf & 0.37 & 0.05 & 0.08 & 20 & 0.04 \\
\hline \multicolumn{6}{|l|}{ Composition (mole fraction) } \\
\hline $\mathrm{CO}_{2}$ & 0.0000 & - & 0.0001 & - & 0.0003 \\
\hline CO & 0.0568 & 0.0072 & 0.0952 & - & 0.0786 \\
\hline $\mathrm{CH}_{4}$ & 0.3018 & 0.0194 & 0.5190 & - & 0.2413 \\
\hline $\mathrm{H}_{2} \mathrm{O}$ & 0.0033 & 0.0008 & 0.0052 & - & 0.0029 \\
\hline $\mathrm{C}_{2} \mathrm{H}_{6}$ & - & - & - & - & - \\
\hline $\mathrm{H}_{2}$ & 0.6015 & 0.9679 & 0.3194 & - & 0.6270 \\
\hline $\mathrm{O}_{2}$ & - & - & - & - & - \\
\hline $\mathrm{N}_{2}$ & 0.0366 & 0.0046 & 0.0610 & - & 0.0498 \\
\hline Sulfur compounds & - & - & - & $\cdot$ & - \\
\hline Oil & - & - & - & - & - \\
\hline Gas Mscfh & 4,685 & 2,038 & 2,651 & - & 3,248 \\
\hline Liquid, gpm & - & - & - & - & - \\
\hline Solid, t/hr & - & - & - & 9.000 & - \\
\hline Molecular weight, fluids & 8.7317 & 2.6086 & 13.4447 & - & 8.7987 \\
\hline
\end{tabular}


Table 4-1 (Contd)

\begin{tabular}{|c|c|c|c|c|}
\hline Stream Number & 63 & 64 & 65 & 66 \\
\hline Description & $\begin{array}{c}\text { MTM } \\
\text { Booster } \\
\text { Gas }\end{array}$ & $\begin{array}{l}\text { Methane } \\
\text { Loop } \\
\text { Bleed }\end{array}$ & $\begin{array}{l}\mathrm{H}_{2} \text { from } \\
\text { Bleed } \\
\text { Membrane }\end{array}$ & $\begin{array}{c}\text { Purge } \\
\text { Gas from } \\
\text { Membrane }\end{array}$ \\
\hline Total flow, t/hr & 35.360 & 1.094 & 0.235 & 0.858 \\
\hline Enthalpy, MMBtu/hr & $\cdot 70.00$ & -1.83 & -.08 & -1.75 \\
\hline Pressure, psig & 303 & 303 & 88 & 301 \\
\hline Temperature, ${ }^{\circ} \mathrm{F}$ & 356 & 356 & 195 & 165.4 \\
\hline Density, Ib/cf & 0.3 & 0.3 & 0.0466 & 0.69 \\
\hline \multicolumn{5}{|c|}{ Composition (mole fraction) } \\
\hline $\mathrm{CO}_{2}$ & 0.0003 & 0.0003 & - & 0.0006 \\
\hline co & 0.0786 & 0.0786 & 0.0261 & 0.1405 \\
\hline $\mathrm{CH}_{4}$ & 0.2413 & 0.2413 & 0.0357 & 0.4840 \\
\hline $\mathrm{H}_{2} \mathrm{O}$ & 0.0029 & 0.0029 & - & 0.0064 \\
\hline $\mathrm{C}_{2} \mathrm{H}_{6}$ & - & - & - & - \\
\hline $\mathrm{H}_{2}$ & 0.6270 & 0.6270 & 0.9267 & 0.2734 \\
\hline $\mathrm{O}_{2}$ & - & - & - & - \\
\hline $\mathbf{N}_{2}$ & 0.0498 & 0.0498 & 0.0115 & 0.0950 \\
\hline Sulfur compounds & - & - & - & - \\
\hline Oil & - & - & - & - \\
\hline Gas Mscth & 3,150 & 97 & 53 & 45 \\
\hline Liquid, gpm & - & - & - & - \\
\hline Solid, $\mathrm{t} / \mathrm{hr}$ & - & - & - & - \\
\hline Molecular weight, fluids & 8.7987 & 8.7987 & 3.4948 & 15.0577 \\
\hline
\end{tabular}




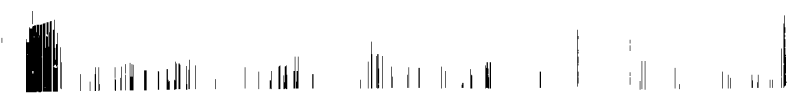

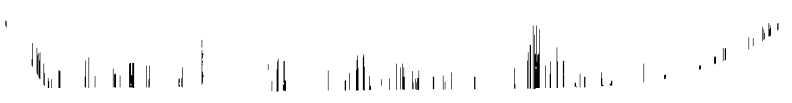
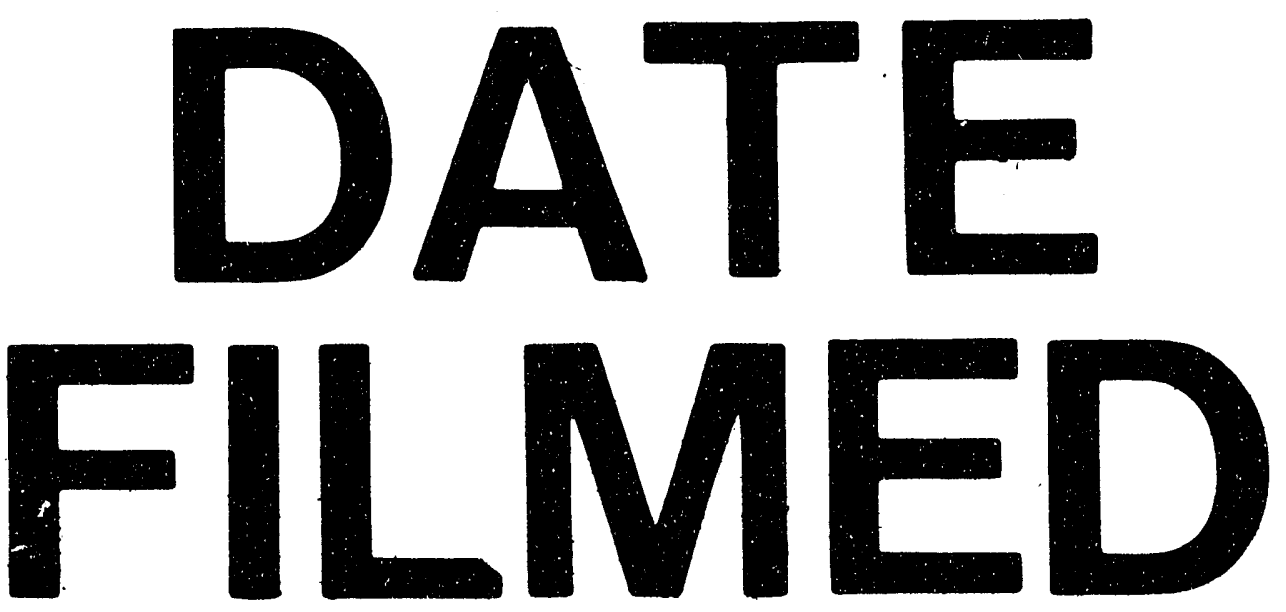

I

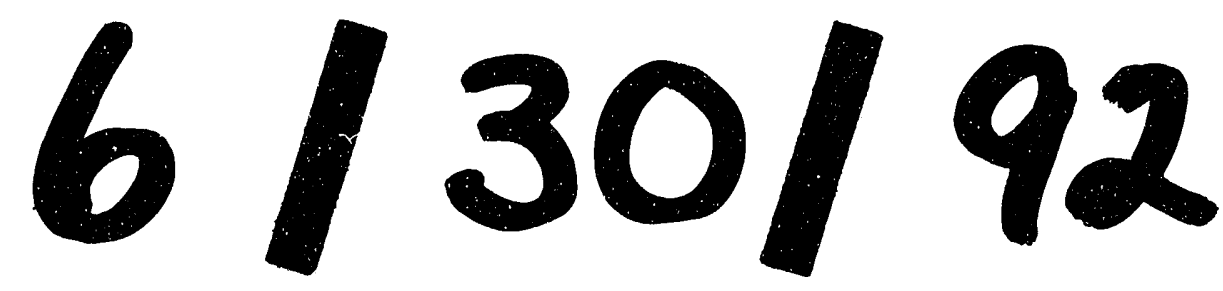


